\title{
THE FEASIBILITY OF RECOVERING MEDIUM TO HEAVY OIL USING GEOPRESSURED-GEOTHERMAL FLUIDS
}

\author{
Jane Negus-de Wys \\ Charles E. Kimmell \\ George F. Hart \\ Martin M. Plum
}

September 1991

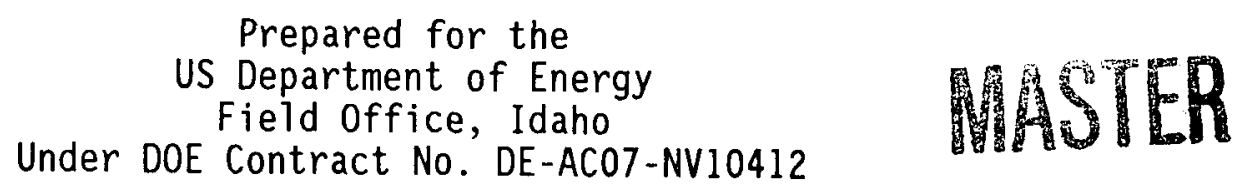




\section{DISCLAIMER}

This report was prepared as an account of work sponsored by an agency of the United States Government. Neither the United States Government nor any agency Thereof, nor any of their employees, makes any warranty, express or implied, or assumes any legal liability or responsibility for the accuracy, completeness, or usefulness of any information, apparatus, product, or process disclosed, or represents that its use would not infringe privately owned rights. Reference herein to any specific commercial product, process, or service by trade name, trademark, manufacturer, or otherwise does not necessarily constitute or imply its endorsement, recommendation, or favoring by the United States Government or any agency thereof. The views and opinions of authors expressed herein do not necessarily state or reflect those of the United States Government or any agency thereof. 


\section{DISCLAIMER}

Portions of this document may be illegible in electronic image products. Images are produced from the best available original document. 


\section{ABSTRACT}

The feasibility, economics and environmental concerns of producing more domestic oil using thermal enhanced oil recovery (TEOR) are reviewed and the unique nature of geopressured-geothermal (GPGT) fluids for thermal recovery are outlined. Current methods of TEOR are briefly discussed and it is noted that these methods are presently under scrutiny by both federal and state air quality agencies; and moreover, they often involve costly operational and mechanical problems associated with heating water on the surface for injection into the target reservoir.

The characteristics of the GPGT resources as seen through previous Department of Energy (DOE) studies from sites in Louisiana and Texas are discussed. These studies indicate sufficient quantities of GPGT fluids can be produced to sustain a TEOR project. The GTadys McCall Well can produce 25,000 to 40,000 bpd for 5 to 7 years at temperatures of about $275^{\circ} \mathrm{F}\left(135^{\circ} \mathrm{C}\right)$. The reservoir pressure is $12,784 \mathrm{psia}$ and the brine chlorinity $57,000 \mathrm{mg} / \mathrm{L}$ with a total dissolved solids (TDS) content of $95,000 \mathrm{mg} / \mathrm{L}$. Dissolved gas was about $25 \mathrm{scf} / \mathrm{bbl}$ of water. The Pleasant Bayou Well demonstrated similar temperatures, pressures $(11,000 \mathrm{psi})$, salinity $(70,000 \mathrm{mg} / \mathrm{L})$, dissolved gas, and water production life but the TDS content was higher $(127,000 \mathrm{mg} / \mathrm{L})$. The Hul in well showed higher temperature $\left(300-375^{\circ} \mathrm{F} ; 149-191^{\circ} \mathrm{C}\right)$ total dissolved solids of $195,000 \mathrm{mg} / \mathrm{L}$ and a gas content of about $34 \mathrm{scf} / \mathrm{bbl}$. The chlorinity was $11,000 \mathrm{mg} / \mathrm{L}$ and the shut-in wellhead pressure was $7,200 \mathrm{psi}$. The Pleasant Bayou Well suggests that practical production rates of $<20,000$ bpd can avoid sanding problems.

The Alworth Field in the south Texas Mirando Trend is proposed as a TEOR pilot site. The temperatures of the Upper Wilcox GPGT fluids in this region range from 350 to $>500^{\circ} \mathrm{F}\left(177\right.$ to $\left.>260^{\circ} \mathrm{C}\right)$, and salinities are in the range of 3,600 to $70,000 \mathrm{mg} / \mathrm{L}$. The pressures are from 1000 to 3,500 psia flowing wellhead pressure. The target reservoirs for injection of the GPGT fluids are the Jackson and Yegua sandstones of the upper Eocene Epoch. These reservoirs 
contain an estimated 4 MMbbls of heavy oil in place (OIP) $\left(18.6^{\circ} \mathrm{API}\right)$ of which it is estimated that at least 1 MMbbls could be recovered by TEOR. Assuming a conservative $80 \mathrm{scf} / \mathrm{bbl}$ gas content of the brine and with temperatures of 350 $500^{\circ} \mathrm{F}\left(177-260^{\circ} \mathrm{C}\right), 3,500 \mathrm{mg} \backslash \mathrm{L}$ TDS, and a recovery of $1,000,000 \mathrm{bbls}$ of crude, a conservative cash flow estimate is $\$ 6,270,928$ per year. Similar estimates can be made for other areas of Texas, Louisiana, and California.

The problems associated with using the GPGT fluids for TEOR include those normally associated with hot water flooding but in addition the reaction of the brine from the geopressured-geothermal reservoir with the target reservoir is uncertain. Under the elevated temperatures associated with GPGT TEOR, actual increased porosity and permeability are possible due to density changes in the clay minerals (smectite to analcime), and associated silica dissolution and thermal decomposition of iron minerals (pyrite and siderite). Estimates by industry of the $0 i 1$ in place and an economic analysis of the TEOR process indicate the great value of the method if it can be successfully implemented. 


\section{EXECUTIVE SUMMARY}

Thermal enhanced oil recovery (TEOR) using geopressured-geothermal (GPGT) fluids is a unique concept for recovering heavy and medium oils that are bypassed during conventional production processes. The successfut implementation of this technology would provide an environmentally clean and less expensive method of thermal recovery as opposed to the burning of crude oil or natural gas used widely by industry at the present time.

The GPGT fluids are under high pressure in their parent reservoir and when linked to shallow reservoirs by suitable plumbing will provide a selfpropelled method of heat transfer to a target reservoir existing at shallow depth. The GPGT fluids will heat the reservoir as in conventional TEOR. This will reduce the residual oil saturation and lower the viscosity of the oil so that it can be moved more easily and in greater amounts.

The method is similar to hot water flooding and thus the basic technology already exists. However, the major difference is the unusually high total dissolved solids (TDS) present in GPGT waters. The exact effect of the brine on the target reservoir is uncertain but may have a beneficial effect not only on viscosity and oil extraction but also on permeability and porosity. The operational and mechanical problems associated with piping the GPGT fluids into shallow reservoirs also are uncertain but probably can be readily overcome. The important point is that an enormous amount of additional domestic heavy and medium oil will be recovered if the concept works. GPGT fluids combine the temperatures, propulsion, and technology that would be comparatively clean environmentaliy.

The United States heavy oil resources show California, Alaska, Arkansas, Louisiana, Texas, and Wyoming as major states from which considerable quantities of additional production is possible (Blevins, 1990). The cumulative production of United States heavy oil as of December 31, 1987, was 12.3 Bbbls with 3.3 Bbbls produced by TEOR. The distribution of heavy oil 
resources shows 42 Bbbls in California, 25 Bbbls in Alaska, 6 Bbbls in Arkansas, Louisiana, and Texas, 5 Bbbls in Wyoming, and 2 Bbbls in other states (Blevins, 1990). The leading basins for application of the technology in the United States include the Gulf Coast Basin, the San Joaquin Basin, and the Los Angeles Basin. Totals for these basins are: 8.134 Bbbls of medium oil and 4.239 Bbbls of heavy oil (DOE, 1989). In Kern County, California, alone $2.5 \mathrm{Bbbls}$ of recoverable heavy oil have been identified.

The report envisages a pilot study within the south Texas Mirando 0il Trend. In this area collocational studies of the GPGT resource and the occurrence of suitable heavy oil reservoirs indicate that the successful implementation of the method would provide an additional 1.5 Bbbls of $0 i 1$ from the 87 fields within the Mirando Trend (Kimme11, 1989, private communication; Negus-de Wys, 1989).

An economic evaluation of the pilot study on Alworth Field in south Texas estimates a cash flow of $\$ 6,270,928$ per year, based on an assumed recovery of 1,000,000 bbls of crude. Recovery could be as high as $2,000,000$ bbls from an estimated 4,000,000 bbls in place. 


\section{ACKNOWLEDGMENTS}

This research was funded by the U.S. Department of Energy, under Contract No. DE-FC07-NV10412.

The authors would like to thank those people who contributed to this project through their reports and discussions. Thanks are expressed to Mr. Don Stevenson at the Louisiana State University (LSU) and Dr. Steve Seni, University of Texas at Austin (UTA) for their contributions.

A special appreciation for document review is extended to $\mathrm{Dr}$. Dave Lombard (DOE-HQ), Dr. W. Harrison (INEL), and DOE-Bartlesville. 


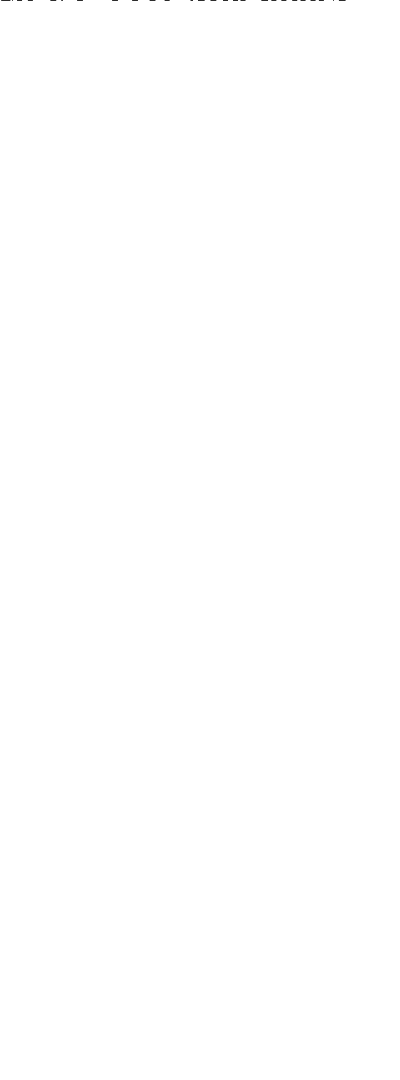




\section{CONTENTS}

ABSTRACT

i i i

EXECUTIVE SUMMARY

ACKNOWLEDGEMENT . . . . . . . . . . . . . . . . . . . . . . . vi i

CONTENTS . . . . . . . . . . . . . . . . . . . . . ix

INTRODUCTION . . . . . . . . . . . . . . . . . . . . . . . . . 1

The Need . . . . . . . . . . . . . . . . . . . 3

THE CURRENT STATUS OF THERMAL METHODS OF RECOVERY . . . . . . . . . . . . . 7

Hot water flooding . . . . . . . . . . . . . . . . . . . . 17

Characteristics of the Geopressured-Geothermal Resource . . . . . . 21

The Gladys McCall Site, Louisiana... . . . . . . . 26

The Pleasant Bayou Site, Texas . . . . . . . . . . . 27

The Hul in Site, Louisiana . . . . . . . . . . . . 29

THERMAL ENHANCED OIL RECOVERY

USING GEOPRESSURED-GEOTHERMAL FLUIDS . . . . . . . . . . . . . . 31

Concept and Methodology . . . . . . . . . . . . . . . . . . . 31

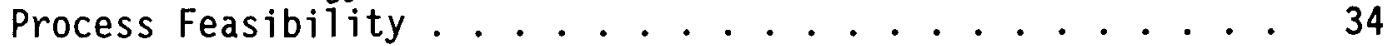

Brine/Hydrocarbon Interaction .. . . . . . . . . . 42

Collocation Studies From Texas .. . . . . . . . . . . . . 45

The Mirando Trend . . . . . . . . . . . . . . . . . . 45

Collocational Studies from Louisiana . . . . . . . . . . . 55

Future Application . . . . . . . . . . . . . . . . . . 60

The San Joaquin Basin, California... . . . . . . . 60

PILOT STUDIES . . . . . . . . . . . . . . . . . . . 67

Alworth Field: South Texas . . . . . . . . . . . . . 67

Location . . . . . . . . . . . . . . . 67 67

Source Reservoir . . . . . . . . . . . . . . . . 67

Target Reservoir ................ . 69

ECONOMIC ANALYSIS . . . . . . . . . . . . . . . . . . . . . 77

ECONOMIC ASSUMPTIONS . . . . . . . . . . . . . . . . . . 85

Financial and Economic Variables . . . . . . . . . . . . 85

Business Type... . . . . . . . . . . . . . . . 85

Debt Ratio and Interest Rate . . . . . . . . . . . 85

Operating Losses . . . . . . . . . . . . . . 86

Liquidity . . . . . . . . . . . . . . . . . 86

Base Year ....................... . 86

Operating Life . . . . . . . . . . . . . . . . 87

Debt Life.................... . . 87

Construction Life . . . . . . . . . . . . . . . . 87

Depreciation and Depreciation Life . . . . . . . . . . 87

Discount Rate... . . . . . . . . . . . . . . . 87

Inflation and Escalation Rates . . . . . . . . . . 88

Depletion Allowance . . . . . . . . . . . . . . 88 
Pre-Operational Variables.................. . . 89

Development Costs.................... . . 89

Well Lease or Purchase . . . . . . . . . . . . . . . 89

Well Study . . . . . . . . . . . . . . . . . . 89

Well Engineering . . . . . . . . . . . . . . . . 89

Well Rework . . . . . . . . . . . . . . . . . . 89

Well Testing ................... . . 90

Production Well Development . . . . . . . . . . . . . 90

Injection Well Development .............. . . 90

Disposal Well Development ............... . 90

Pipeline Right-of-Way Costs . . . . . . . . . . . . . . 90

Brine Line Cost . . . . . . . . . . . . . . . . . . 90

Gas Transmission Line . . . . . . . . . . . . . . . . 99 90

Equipment Costs . . . . . . . . . . . . . . . . . 91

Site Upgrade ....................... . . 91

Working Funds . . . . . . . . . . . . . . . . . . . 91

Contingency . . . . . . . . . . . . . . . . . . 91

Capitalized Interest . . . . . . . . . . . . . . 91

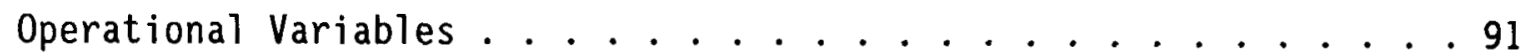

Labor, Administration, Overhead . . . . . . . . . . . 92

Royalty ...................... . . . 92

Direct Maintenance . . . . . . . . . . . . . . . 92

Direct Materials . . . . . . . . . . . . . . . . . . 92

Liability and Operators Insurance . . . . . . . . . . . . 92

Data Collection, Lab Analysis... . . . . . . . . . . . 93

Contingencies . . . . . . . . . . . . . . . . . . 93

Federa1, State, and Local Taxes.............. . . . 93

Production Decline .. . . . . . . . . . . . . . . 93

Operating Factor .................... . 93

Operating Rates..................... . 93

Post-Operational Variables .................. 94

Results.......................... . 94

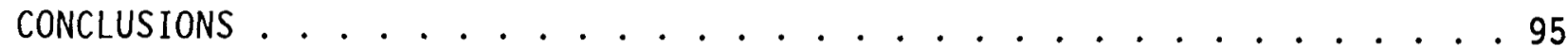

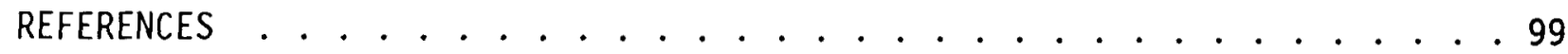




\section{FIGURES}

1. Proportions of crude oil imported into the USA: 1978-1988

(Includes imported crude for the strategic petroleum reserve).

Source: Energy Information Administration

2. United States enhanced oil recovery production. Source: Energy

Information Administration

3. 0il viscosity as a function of temperature and gravity.

Source: Farouq \& Meldau

4. $0 i 1$ recovery mechanisms. Source: Moritas, 1990 . . . . . . 11

5. Heavy oil resources in the United States. Source: Kuuskraa \& Godec (1987) for DOE, Bartlesville Project Office (Interstate 0i1 Compact Commission)

6. History of steam flooding. Source: Blevins, 1990 . . . . . . 18

7. Worldwide occurrence of abnormal formation pressure. Source: Fertl et a1., 1976

8. Location of geopressured basins, heavy oil and tar sands in the United States. Source: Strongin (1981) \& Meyer (private communication,

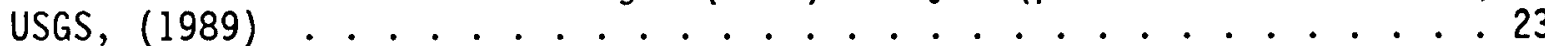

9. Depth - pressure relationship of the geopressured zone. Source: Bradley, 1975

10. Map Showing the Location of the three current GPGT prospects: Gladys McCall, Hul in, and Pleasant Bayou. Source: John et a1., 1990 . . . 26

11. Graph Showing the Daily Production of Brine During the Last Two Years of Testing at Gladys McCall (Data from Eaton Operating Company, 1987). Source: John et al., 1990 . . . . . . . . . 28

12. Contribution of viscosity reduction to the efficiency of heavy oil recovery. Source: Belvins, 1990 ............. 32

13. Contribution of viscosity reduction to $0 i 1$ recovery. Source: Belvins, 1990

14. Alternative reactions in target reservoirs with injection of GPGT brine. Source: Ferrell, personal communication, 1990 . . . . 37

15. Triplot showing the three major kinds of porosity occurring in detrital target reservoirs. Source: Ferrell, personal communication, 1990 
16. Possible mineral reactions accompanying GPGT TEOR. Source:

Ferre11, personal communication, 1990. "In a" = log-normal

activity of $\mathrm{Na}$ and $\mathrm{H} \ldots \ldots . \ldots 38$

17. Variations in temperature and geostatic ratio (psi/ft) with depth, Louisiana Gulf Coast. Source: After Hanor \& Bailey, 1983 from

Bailey, $1978 \ldots \ldots . \ldots . \ldots . . \ldots 42$

18. Salinity of pore waters $(g / 1)$ calculated from electric logs,

Louisiana Gulf Coast. Source: After Hanor \& Bailey, 1983 from

Bailey, 1978

19. Calculated Values of hydraulic head in feet above sea level.

All head values are normalized to a pore fluid specific weight of $67.0 \mathrm{lb} / \mathrm{ft}$, which corresponds to a density of approximately $1.07 \mathrm{~g} / \mathrm{cm}$. A head value of 9,000 feet represents a pore fluid pressure sufficient to raise a column of brine 9,000 feet above sea level. Source: After Hanor \& Bailey, 1983 from Bailey, 1978 . . . 44

20. Location map of heavy oils of south Texas showing the Mirando Trend and the location of the Alworth Field. Source: Haml in et al., 1990 . 46

21. Map showing average fluid-temperature distribution for Deep Upper Wilcox, South Texas. Source: Haml in et al., $1990 \ldots . . . . . .50$

22. Map showing average fluid-pressure distribution for Deep Upper Wilcox, south Texas. Source: Haml in et al., $1990 \ldots 51$

23. Map showing net sandstone thickness for Deep Upper Wilcox, South Texas. Source: Haml in et al., 1990 . . . . . . . . . . 52

24. Map showing average porosity for Deep Upper Wilcox, South Texas. Source: Haml in et al.,1990 . . . . . . . . . . . . . 53

25. Map showing average pore fluid salinity for Deep Upper Wilcox,

South Texas. Source: Haml in et al.,1990 ........... 54

26. Histogram of the number of heavy oil sites by depth. Source: Hart \& Evans, data files based on Conservation Department, LA . . . . 56

27. Histogram of the number of medium oil sites by depth. Source: Hart \& Evans, data files based on Conservation Department, LA . . . . . 57

28. Distribution and depth to the top of geopressure sands, Louisiana. Source: McCulloh et al., 1986 . . . . . . . . . . . 59

29. Subsurface map of the central part of the San Joaquin Basin showing principal locations. Source: Graham \& Williams, $1984 \ldots 61$

30. Heavy 0il Production Compared with San Joaquin Basin Kern 0il County Recoverable Heavy 0il. Source: Graham \& Williams, 1984 ...... 62 
31. Geothermal gradient for the central part of the San Joaquin Basin. Source: Graham \& Williams, $1984 \ldots . . . . . . .61$

32. Fluid Pressure Regions in California. Source: Berry, 1973 . . . . 65

33. Structure map on top of the cole sandstone, Alworth Field . . . . . 72

34. Isopach map of the oil column in the cole sandstone, Alworth Field . . 73

35. Temperature distribution in a 10 acre line drive: $338^{\circ}$ injection water. Eaton et al., $1989 \ldots \ldots 76$

36. Temperature distribution in a 10 acre line drive: $482^{\circ}$ injection water. Eaton et al., $1989 \ldots \ldots 76$

37. Calculated recoveries for different waterfloods. Source: Spillette \& Nielson, 1968 ................... . . 82

38. Crude oil supply to 2,000 AD (by export region). Source: Belvins, $1990 \ldots . \ldots . \ldots 94$

39. Crude oil consumption to 2,000 AD (USA). Source: Belvins, 1990 . . 95

40. Crude oil price outlook to 2,100. Source: Belvins, $1990 \ldots 95$ 


\section{TABLES}

1. 0il supply and demand for the USA: 1988 to 1994.

Source: Beck, 1990

2. United States TEOR production.

Source: Moritas, 1990

3. Active TEOR projects: 1971 to 1990.

Source: Moritas, 1990

4. Producing hot water TEOR projects in the United States.

Source: Moritas, 1990 .................. 13

5. Screening criteria for successful steam floods.

Source: Prats, 1978 . . . . . . . . . . . . . 14

6. United States TEOR scope. Source: Prats, $1978 \ldots \ldots 14$

7. Leading basins in the United States for ultimate recovery

of light, medium, and heavy oil. Source: DOE, 1989 ........ 15

8. Wells, brine, and reservoir characteristics for the three Department of Energy Geopressured-Geothermal wells.

Source: Eaton 0il Company, DOE Program Reports, Geothermal

Reviews, University of Texas at Austin, Louisiana State

University, and INEL .................. 25

9. Reservoir thermal properties, Alworth Field, South Texas . . . . . 70

10. Summary reservoir data sheet, Alworth Field, South Texas . . . . . 71

11. Economic input data for evaluation of Alworth Field . . . . . 78

12. Production Scenario 1 ................ 80

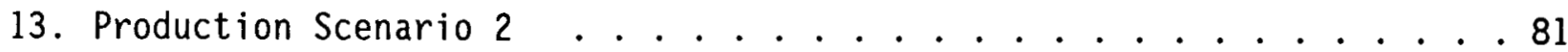




\section{THE FEASIBILITY OF RECOVERING MEDIUM TO HEAVY OIL USING GEOPRESSURED-GEOTHERMAL FLUIDS}

\section{INTRODUCTION}

The geopressured-geothermal (GPGT) aquifers contain chemical, thermal, and mechanical energy. Ideally GPGT usage should be a total energy system that uses the chemical energy of the dissolved and pressurized methane; the thermal energy of the hot brine for direct heating and thermal enhanced $0 i 1$ recovery (TEOR); and, the mechanical energy of the high flow rates for electricity generation. Currently, the technologies have not been brought together but are in various stages of development.

The objective of this study is to examine the feasibility and economics of thermal enhanced oil recovery using geopressured-geothermal fluids. In order to assess the GPGT TEOR potential of an area the level of understanding of the geology of both the source and target reservoirs must be considered in addition to the technology of brine production, surface handling and injection, and the production and marketing of the oil obtained from the target reservoir. Many of the parameters important to this analysis are site specific. Within an economic model major effects include pre-operational and development capital costs, operating costs, and post operation costs, especially brine well and target well characteristics, and specific production facility characteristics. Superimposed on these considerations is the well known prerequisite of successful engineering ventures: economic feasibility. Economic feasibility implies profitability by some measure. The simple economic model may be overshadowed by either one or both of two significant intangible parameters.

1. The need for a politically secure and militarily defensible resource, and

2. The need for an environmentally acceptable method of TEOR (See Appendix B). 
Economic input for this study was obtained from operators presently involved in the $0 i 1$ and gas business with knowledge of geopressured-geothermal reservoirs, and with histories of successful operation. Collocational studies of target reservoirs with medium to heavy $0 i 1$ and associated deeper reservoirs with GPGT fluids focused on the south Texas Rio Grande Embayment area, southern Louisiana, and Kern County, California. A specific example of an economic evaluation is presented for the Alworth Field in south Texas. The method of evaluation can be applied to other fields, by using the appropriate input data and assumptions. 


\section{THE NEED}

It was not until the 1973 Arab oil embargo that energy supplies were fully recognized as a serious problem. Since that time, energy prices have contributed substantially to the inflationary spiral, and threaten not only the security of the USA but also its position as a world leader. Desert Storm further emphasized the seriousness of this complex situation. The ratio of United States oil imports to oil production moved to a new high in 1990 when $51 \%$ of the oil used in the United States was imported (Wall Street Journal, 1990). The projected outlook for supply and demand of the United States through 1994 shows an increasing deficit (Table 1). It takes a major effort even to replace production, and approximately $90,000,000$ bbls and 400 bcf gas must be found annually just for replacement.

Table 1. Oil supply and demand for the USA: 1988 TO 1994 Source: Beck, 1990

\begin{tabular}{|c|c|c|c|c|c|c|c|c|}
\hline PETROLEUM BALANCE [Mbpd] & 1988 & 1989 & 1990 & 1991 & 1992 & 1993 & 1994 & $\begin{array}{l}\text { Change } \\
\text { value } \%\end{array}$ \\
\hline \multicolumn{9}{|l|}{ DEMAND } \\
\hline Domest ic demand & 17,283 & 17.560 & 17,830 & 18,070 & 18,410 & 18,660 & 18,910 & 1,350 \\
\hline Exports & 815 & 820 & 830 & 840 & 850 & 860 & 870 & 6.1 \\
\hline Total demand & 18,098 & 18,838 & 18.660 & 18,910 & 19.260 & 19.520 & 19,780 & 1,400 \\
\hline \multicolumn{9}{|l|}{ SUPPLY } \\
\hline Crude production & 8,140 & 7,775 & 7,585 & 7,385 & 7,165 & 7.020 & 6,980 & $-795-10.2$ \\
\hline $\mathrm{NGL}+$ other $H C^{\prime} s$ & 1,678 & 1.680 & 1,700 & 1.720 & 1,740 & 1,760 & 1,780 & $100 \quad 6.0$ \\
\hline Total liquid production & 9.818 & 9.455 & 9,285 & 9,105 & 8.905 & 8,780 & 8,760 & $-695-7.4$ \\
\hline Crude imports [ex.SPR] & 5,055 & 5,800 & 6.230 & 6.630 & 7.135 & 7.460 & 7.710 & $1.910 \quad 32.9$ \\
\hline Product imports & 2.293 & 2,305 & 2,320 & 2,345 & 2,400 & 2,440 & 2,480 & $175 \quad 7.6$ \\
\hline Total industry imports & 7,348 & 8,105 & 8,550 & 8,975 & 9,535 & 9,900 & 10,190 & $2.085 \quad 25.7$ \\
\hline Other supply & 851 & 865 & 865 & 870 & 875 & 880 & 885 & 2.3 \\
\hline TOTAL SUPPLY & 18,071 & 18,425 & 18,700 & 18.950 & 19,315 & 19.560 & 19.835 & 1,410 \\
\hline
\end{tabular}


Figure 1 shows the proportion of crude $0 i 1$ imported into the United States and suggests the extent of future vulnerability of the economy. The effect of oil scarcity can be seen through numerous indicators. The price of oil company stocks reflected the recent mideast crisis and generally rattled the world economy. For example, Exxon stock rose to over $\$ 53$ per share after lingering at $\$ 42-43$ per share in the mid-1980's. At the local level the price of unleaded gasoline rose more than 16 cents per gallon in 1 week as a result of the invasion of Kuwait by Iraq (Associated Press, August 1990); and over 30 cents per gallon within a month (PBS News, August 1990). Concern over the security of the oil supply from Saudi Arabia (which supplies the bulk of the U.S. imports) precipitated the military buildup and political polarization of August 1990. To put this petroleum region in perspective, the Ghawar Field in Saudi Arabia is the largest oil field in the world. It has an order-ofmagnitude more reserves than Prudhoe Bay, which in turn, is an order-ofmagnitude larger than the Oseberg Field in the North Sea. The Arabian peninsula is underlain by a carbonate platform that contains the abundant oil that makes the Ghawar Field so valuable. The Ghawar Field is just one development in a vast accumulation of hydrocarbons. The really chilling effect on developing domestic oil supplies is the fact that it costs $\$ 3.75$ more to produce one barrel of oil in the USA than in Saudi Arabia (ABC News, August 1990). As the projected United States oil demand and supply becomes a reality so will the political and military maneuvers of the United States reflect the balance of oil supply and demand. Alternative energy forms that can alter the energy balance are of great importance; and creative methods of oil recovery can be an important factor in altering the imbalance. GPGT TEOR possibly offers a major attractive methodology for increasing the domestic supply of crude oil.

A further factor of increasing significance is the demand by the American public for a clean environment. Environmental laws are inhibiting the expansion of steam TEOR projects in California because the crude oil used to generate steam is high in sulfur and is polluting the local atmosphere. Deterioration of air quality comes from both the steam generation process and 


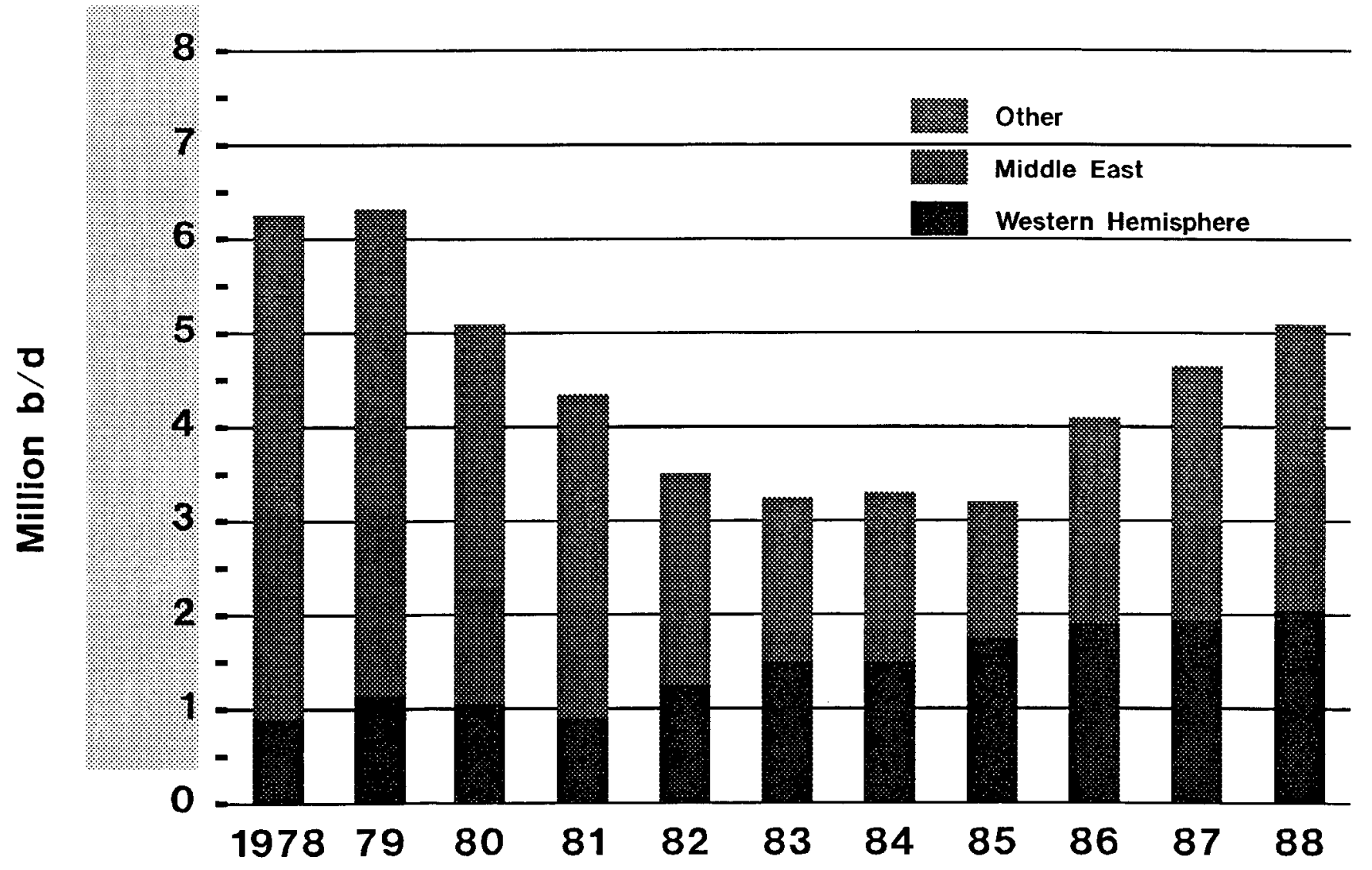

Figure 1. Proportions of crude oil imported into the USA: 1978-1988 (includes imported crude for the strategic petroleum reserve). Source: Energy Information Administration. 
the pumping of the steam down the hole (Moritas, 1990). In addition to the pollution problem is that of access to a fresh water resource. Potable water is used for steam generation in conventional TEOR and this is at a premium in California and south Texas. Thermal extraction of medium and heavy oils using GPGT fluids would provide not only an environmentally clean method of recovery, but also a method that does not utilize the fresh water supply. Moreover, a bonus to the investor is that it does not generate the very expensive operational and mechanical problems that occur in heating.

Finally, it should be noted that a considerable effort is spent searching for new production outside of the USA because it is generally thought that most major discoveries in North America have been made, and that production costs are lower elsewhere. Certainly, the idea that the majority of large fields have been discovered is a reasonable statement in terms of using the technology of the last decade. However, billions of barrels of extra oil may be produced in the Gulf Coast and other regions of North America if a more aggressive stance is taken about using thermal enhanced oil recovery and creating the technology to produce more from existing fields. Even a $5 \%$ improved production will pay for the risk because the areas for possible applications are numerous. New inventions that can provide a technological edge are becoming available. For example, a recently patented down-hole thermal tool should provide an accurate and continuous $10 \mathrm{~g}$ of the rock conductivity, the porosity and the fluid saturations (DesBrandes, 1989; Hui \& DesBrandes, 1989). This tool could serve an extremely important purpose for understanding the characteristics of the target reservoir and the engineering requirements for hot fluid injection when GPGT fluids are used for TEOR.

The concept of using GPGT fluids for TEOR is a creative one but it will demand risk because the frontier being probed is uncertain. 


\section{THE CURRENT STATUS OF THERMAL METHODS OF RECOVERY}

Using conventional recovery methods, an average of about $65 \%$ of the $0 i 1$ remains in the reservoir. This remaining $0 i 1$ is retained within the pore space by capillary, gravitational, and viscous forces. A lot of this oil probably will never be fully recovered due to unfavorable geological characteristics of the reservoir but much of it can be extracted by EOR technology. An important consideration in Louisiana is that recovery efficiencies "are often very high in the numerous high quality waterdrive reservoirs in south Louisiana, averaging $50.4 \%$ compared to $33 \%$ for the U.S. average. Recovery can be as much as $85 \%$ leaving remaining $0 i 1$ saturations too low to warrant additional recovery efforts" (Durham, 1980). If the oil is highly viscous, $5 \%$ or less recovery is common, and for very viscous bitumens conventional recoveries are essentially 0\% (Boberg, 1988).

The recognized methods of EOR are based on either thermal processes, chemical processes, or miscible displacement processes. Thermal methods account for the bulk of the world's EOR production, and today over $800,000 \mathrm{bbl} /$ day of heavy to medium $0 i 1$ are recovered by steam flooding alone. Thermal methods account for about $78 \%$ of EOR production in the U.S. (Table 2).

Table 2. United States TEOR production

\begin{tabular}{||l|r|r|r|r|r|r|r||}
\hline Units in bbls/day & 1980 & 1982 & 1984 & 1986 & 1988 & 1990 & $\%$ \\
\hline Thermal & & & & & & & \\
\hline Steam & 243,477 & 288,396 & 358,115 & 468,692 & 455,484 & 444,137 & -2.5 \\
\hline $\begin{array}{l}\text { Combust ion in } \\
\text { situ }\end{array}$ & 12,133 & 10,228 & 6,445 & 10,272 & 6,525 & 6,090 & -6.7 \\
\hline Hot water & 0 & 0 & 0 & 705 & 2,896 & 3,985 & 37.6 \\
\hline TOTAL THERMAL & $\mathbf{2 5 5 , 6 1 0}$ & $\mathbf{2 9 8 , 6 2 4}$ & $\mathbf{3 6 4 , 5 6 0}$ & $\mathbf{4 7 9 , 6 6 9}$ & $\mathbf{4 6 4 , 9 0 5}$ & $\mathbf{4 5 4 , 2 1 2}$ & $\mathbf{- 2 . 3}$ \\
\hline
\end{tabular}

Thermal enhanced $0 i 1$ recovery (TEOR) represents about 7\% of the total United States production (Moritas, 1990). The San Joaquin Basin, California, provides the most heavy oil production in the United States and almost all TEOR output $(400,000 \mathrm{bbl} / \mathrm{day})$. Steam processes are by far the major TEOR methods used. Beginning in 1986 hot water flooding methods commenced and have 
increased by a considerable factor since that time. Although the total number of EOR projects (Figure 2) currently is declining, the total production from EOR projects is increasing, suggesting that more efficient and effective EOR processes are being employed (Moritas, 1990).

The basic principle of the TEOR method is that the lower the viscosity of the oil the better it flows into the producing well; and, by increasing the temperature of the oil reservoirs, the viscosity of the oil and the residual oil saturation can be lowered. The application of TEOR to high porosity reservoirs containing low gravity, high viscosity oils is now routine. Negus-de Wys, (1989) showed the relationship of temperature to viscosity for bitumens ( $<10^{\circ} \mathrm{API}$ gravity), heavy oil ( 10 to $20^{\circ} \mathrm{API}$ gravity), medium oils ( $>20$ to $25^{\circ} \mathrm{API}$ gravity), and $18.6^{\circ} \mathrm{API}$ gravity oil the Alworth Field (Figure 3 ).

Thermal recovery methods include steam stimulation, steam flooding (including hot water injection), In situ combustion, and electromagnetic heating (Figure 4). In situ combustion and electromagnetic heating do not relate to the proposed methods for utilizing GPGT fluids. However, the steam methods do. Steam stimulation (cyclic steam injection, steam soak, or huff and puff) employs one well for both injection and production. Steam (about $1,000 \mathrm{bbl} /$ day) is injected into the reservoir and left to soak for 2 to 3 weeks. The well is then shut in for a few days to allow heat dissipation, and then produced. The main effect is the reduction in the viscosity of the oil. The steam vapor is rapidly condensed to water and the product is oil and water. Steam flooding (steam drive) consists of continuously injecting steam into a central well to reduce the oil viscosity and drive the oil, gases, and water to surrounding production wells. Initially the oil is displaced by steam drive and steam distillation. When heated, the lighter fractions of the trapped oil are distilled and become mobile. Steamfloods are commonly used after steam stimulation has recovered the oil in the immediate area around the well bore. The actual agent in steam flooding is hot water since the steam is rapidly condensed. As the temperature reduces with distance from the well bore the steam condenses to hot water and this causes thermal expansion of the 


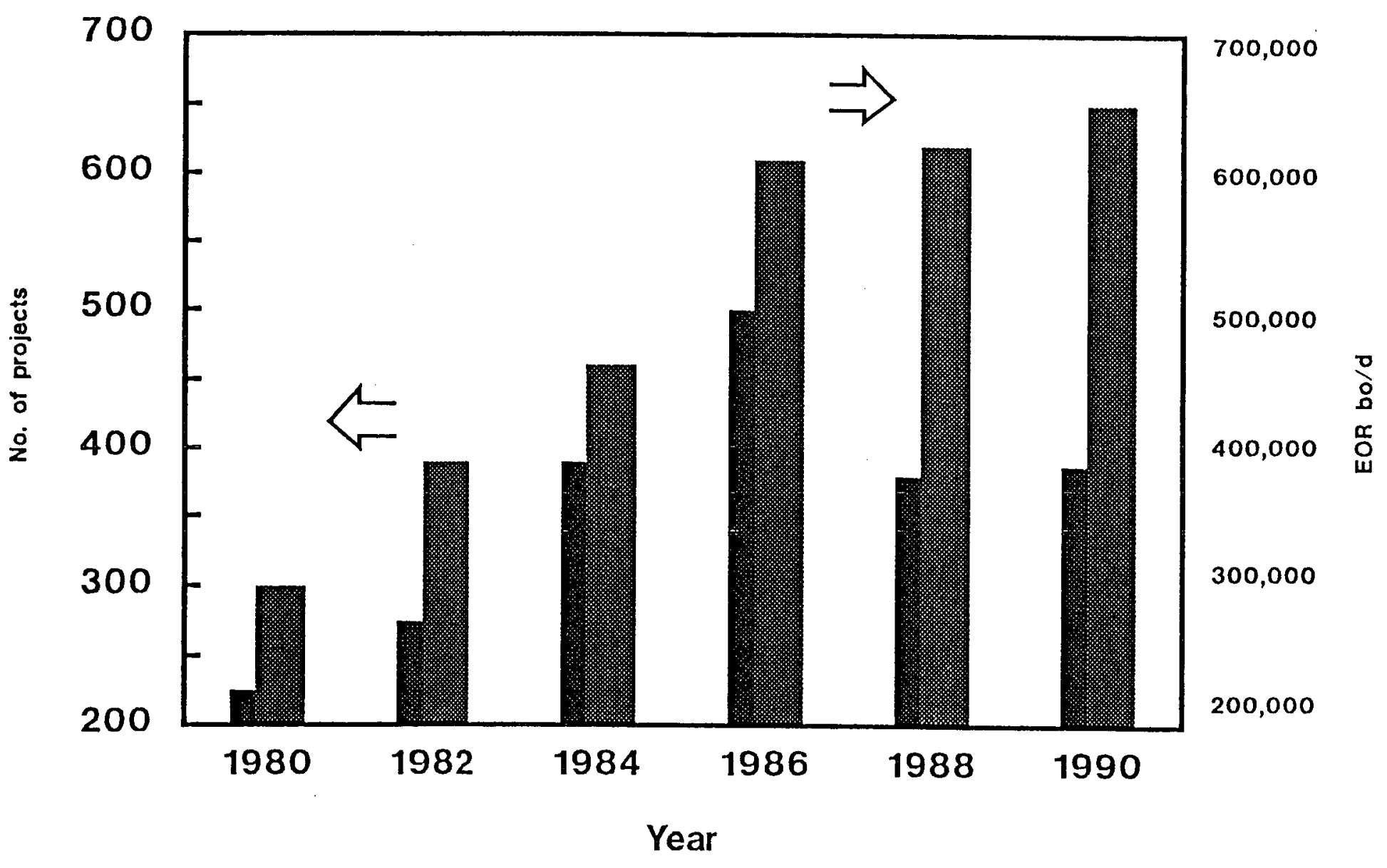

Figure 2. United States enhanced oil recovery production. Source: Moritas, 1990. 


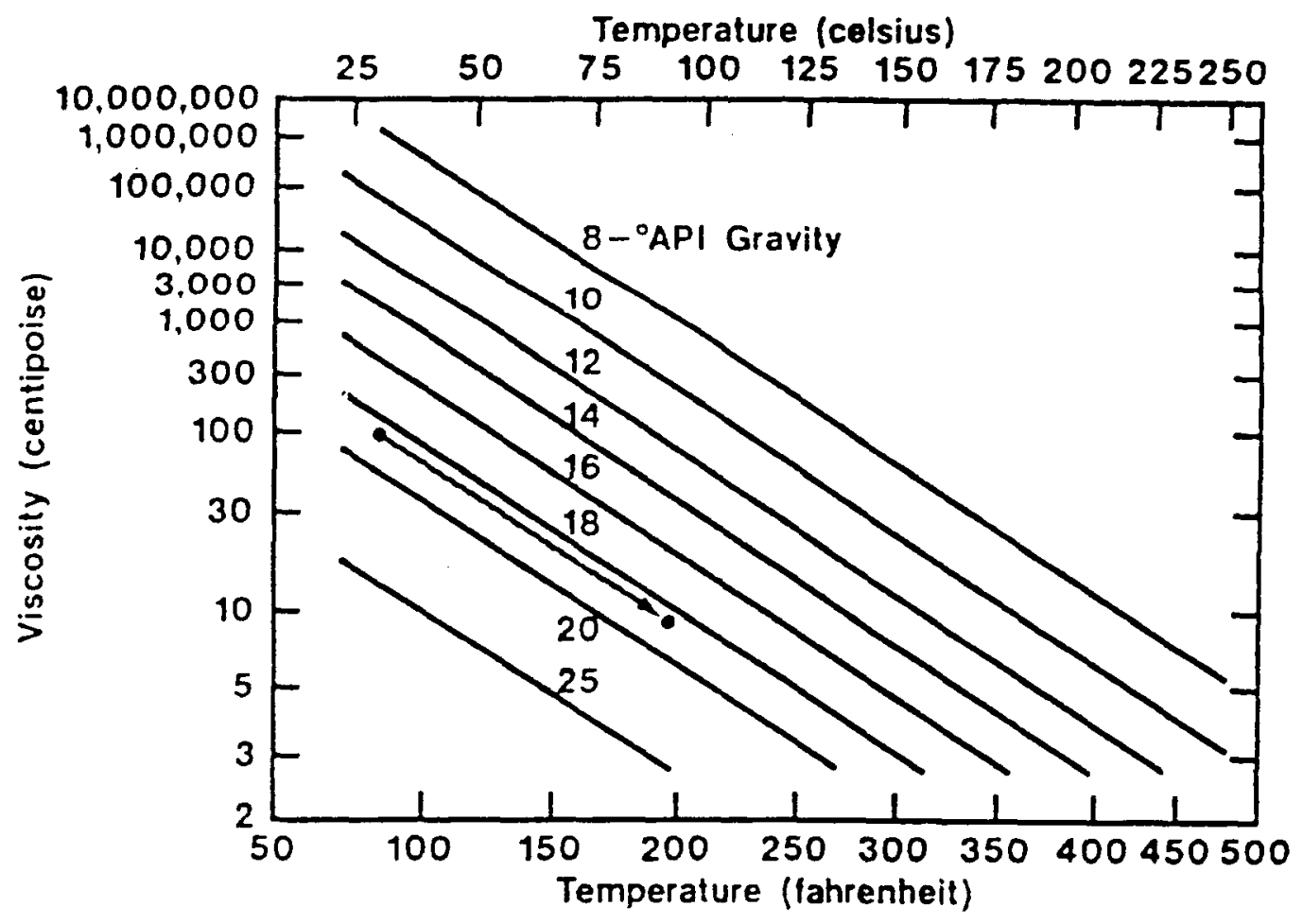

Figure 3. 0il viscosity as a function of temperature and gravity. Source: Farouq \& Meldau. 


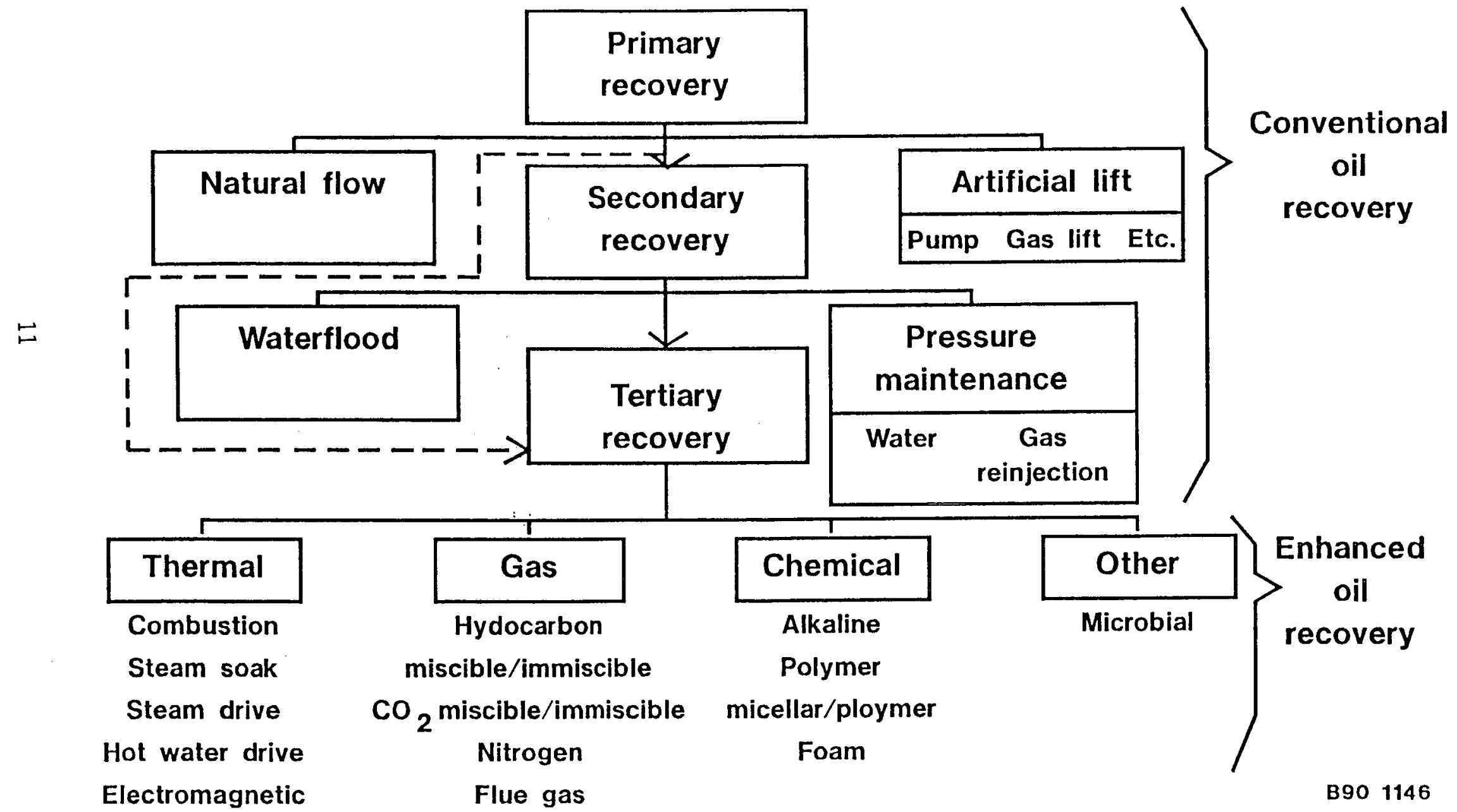

Figure 4. 0 il recovery mechanisms.

Source: Moritas, 1990 
fluids, reduction of viscosity and residual oil saturation, compression of the solution gas, and changes in relative permeability. The process may clean up the well and improve local permeability. Combustion of the oil in the reservoir often creates a steam bank following simple steam flooding. The steam, combustion gas, and evaporated hydrocarbons drive the reservoir oil, gas, and water into the producing well. Oxygen or air is injected to maintain combustion, and because no heat is lost, the combination process can be used for deeper reservoirs than simple steam methods. The number of active steam flooding projects undertaken since 1971 is shown in (Table 3). Present TEOR projects in the United States total 154, with nine using hot water flooding (Tables 3 and 4 ).

Table 3. Active TEOR projects: 1971 to 1990 (Moritas, 1990)

\begin{tabular}{||l|c|c|c|c|c|c|c|c|c|c|c||}
\hline F projects & 1971 & 1974 & 1976 & 1978 & 1980 & 1982 & 1984 & 1986 & 1988 & 1990 & $\%$ \\
\hline $\begin{array}{l}\text { Therma 1 } \\
\text { Steam }\end{array}$ & 53 & 64 & 85 & 99 & 133 & 118 & 133 & 181 & 133 & 137 & 3.0 \\
\hline $\begin{array}{l}\text { Combus ion } \\
\text { in situ }\end{array}$ & 38 & 19 & 21 & 16 & 17 & 21 & 18 & 17 & 9 & 8 & -11.1 \\
\hline Hot water & 0 & 0 & 0 & 0 & 0 & 0 & 0 & 0 & 10 & 9 & -10.0 \\
\hline \begin{tabular}{l} 
TOTAL \\
\hline
\end{tabular} & 91 & $\mathbf{8 3}$ & $\mathbf{1 0 6}$ & 115 & $\mathbf{1 5 0}$ & $\mathbf{1 3 9}$ & 151 & 201 & 152 & 154 & 1.3 \\
\hline
\end{tabular}

No new hot water projects are planned for initiation in the United States in the immediate future, but a total of five steam projects are planned, for Kern County, California (3), Iberville Parish, Louisiana, and Hardin County, Texas (Table 4) (Moritas, 1990). Because of the similarity between steam flooding and the use of GPGT fluids, the methods, applications, and successes of steam flooding are relevant to use of GPGT fluids for TEOR. Table 5 shows the screening criteria that are used for determining a successful steamflood program. These criteria probably are useful as an initial screening test for GPGT TEOR projects. The third column in Table 5 shows the screening data for the Alworth Field. The scope of TEOR projects in terms of size, depth, and oil gravity are presented in Table 6. 


\begin{tabular}{|c|c|c|c|c|c|c|c|c|c|c|}
\hline Operator & Field & State & County & $\begin{array}{l}\text { Start } \\
\text { Date }\end{array}$ & $\begin{array}{l}\text { Area } \\
\text { Acres }\end{array}$ & $\begin{array}{l}\text { - Number } \\
\text { Prod }\end{array}$ & $\begin{array}{c}\text { we } 11 s- \\
\text { Inj. }\end{array}$ & Pay Zone & $\begin{array}{r}\text { Formation } \\
\text { Type }\end{array}$ & $\begin{array}{r}\text { Poro } \\
\text { sity } \\
\%\end{array}$ \\
\hline $\begin{array}{l}\text { Hot water } \\
\text { ARCO } \\
\text { ARCO } \\
\text { ARCO } \\
\text { Mobil } \\
\text { Santa Fe } \\
\text { Energy } \\
\text { Texaco } \\
\text { Texaco } \\
\text { Texaco } \\
\text { Texaco }\end{array}$ & $\begin{array}{l}\text { Kern River } \\
\text { Kern River } \\
\text { MidwaySunset } \\
\text { S.Beltridge } \\
\text { Kern River } \\
\text { Lost Hills } \\
\text { Lost Hills } \\
\text { McKittrick } \\
\text { San Arao }\end{array}$ & $\begin{array}{l}C A \\
C A \\
C A \\
C A \\
C A \\
C A \\
C A \\
C A \\
C A\end{array}$ & $\begin{array}{l}\text { Bakersfield } \\
\text { Bakersfield } \\
\text { Kern } \\
\text { Kern } \\
\text { Kern } \\
\text { Kern } \\
\text { Kern } \\
\text { Kern } \\
\text { Monterey }\end{array}$ & $\begin{array}{l}1986 \\
1986 \\
8 / 85 \\
11 / 82 \\
1 / 80 \\
1 / 86 \\
1 / 86 \\
1981 \\
9 / 86\end{array}$ & $\begin{array}{r}50 \\
28 \\
6 \\
242 \\
\\
150 \\
11 \\
38 \\
12 \\
240\end{array}$ & $\begin{array}{r}45 \\
42 \\
6 \\
54 \\
\\
101 \\
13 \\
31 \\
50 \\
62\end{array}$ & $\begin{array}{r}10 \\
11 \\
2 \\
8 \\
\\
57 \\
4 \\
13 \\
14 \\
24\end{array}$ & $\begin{array}{l}\text { Kern River Ser. } \\
\text { Kern River Ser. } \\
\text { Tulare } \\
\text { Tulare } \\
\text { Rern River } \\
\text { Tulare } \\
\text { Etchepoin } \\
\text { Potter } \\
\text { Aungnac }\end{array}$ & $\begin{array}{l}S \\
S \\
S \\
U S \\
S \\
S \\
S \\
S \\
S\end{array}$ & $\begin{array}{l}31.0 \\
31.0 \\
33.0 \\
36.8 \\
\\
30.0 \\
38.0 \\
40.0 \\
35.0 \\
33.0\end{array}$ \\
\hline
\end{tabular}

\begin{tabular}{|c|c|c|c|c|c|c|c|c|c|c|c|c|c|}
\hline $\begin{array}{l}\text { Permeability } \\
\text { md }\end{array}$ & $\begin{array}{c}\text { Depth } \\
\mathrm{ft} .\end{array}$ & $\begin{array}{l}\text { Gravity } \\
\text { API } \\
\end{array}$ & $\begin{array}{c}\text { Reservo } \\
\mathrm{cp} \\
\end{array}$ & oil & $\begin{array}{l}\text { Satur. } \\
\text { Prev. } \\
\text { prod }\end{array}$ & $\begin{array}{c}\text { Satur. } \\
\% \\
\text { start }\end{array}$ & $\begin{array}{c}\text { Total } \\
\% \\
\text { end }\end{array}$ & $\begin{array}{l}\text { Enh. } \\
\text { Proj. } \\
\text { matur. }\end{array}$ & $\begin{array}{l}\text { prod. } \\
\text { b/d }\end{array}$ & $\begin{array}{l}\text { proj. } \\
\text { b/d }\end{array}$ & $\begin{array}{l}\text { Proj. } \\
\text { evaj. }\end{array}$ & Profit & $\begin{array}{l}\text { Proj. } \\
\text { scope }\end{array}$ \\
\hline $\begin{array}{r}3,000 \\
2,500 \\
2,500 \\
3,000 \\
100.3,000 \\
2,000 \\
2,000 \\
4,000 \\
3,000\end{array}$ & $\begin{array}{r}900 \\
600 \\
1,000 \\
1.000 \\
700 \\
200 \\
400 \\
1,100 \\
2,200\end{array}$ & $\begin{array}{l}13.5 \\
13.5 \\
11.0 \\
14.0 \\
13.0 \\
13.0 \\
13.0 \\
13.0 \\
13.0\end{array}$ & $\begin{array}{r}8,000 \\
5,000 \\
24,000 \\
1,600 \\
4,000 \\
20 \\
10 \\
40 \\
4,000\end{array}$ & $\begin{array}{r}90 \\
78 \\
100 \\
95 \\
85 \\
250 \\
250 \\
210 \\
100\end{array}$ & $\begin{array}{l}\text { S } \\
\text { S } \\
\text { SF } \\
\text { SF } \\
\text { Pnm } \\
\text { SF } \\
\text { SF } \\
\text { SF } \\
\text { S }\end{array}$ & $\begin{array}{c}30 \\
35 \\
20 \\
37.1 \\
45\end{array}$ & $\begin{array}{l}20.0 \\
20.0 \\
10.0 \\
28.2 \\
15.0 \\
\\
\\
30.0 \\
31.0\end{array}$ & $\begin{array}{l}H F \\
H F \\
N C \\
H G \\
N C \\
N C \\
H G \\
H G \\
J S\end{array}$ & $\begin{array}{r}200 \\
200 \\
\\
2,200 \\
1,600 \\
125 \\
150 \\
300 \\
650\end{array}$ & $\begin{array}{r}130 \\
50 \\
\\
2,200 \\
1,200 \\
125 \\
150 \\
30 \\
100\end{array}$ & $\begin{array}{l}\text { Succ } \\
\text { Prom } \\
\text { Disc } \\
\text { Prom } \\
\text { Succ } \\
\text { Succ } \\
\text { Succ } \\
\text { Disc } \\
\text { TETT }\end{array}$ & $\begin{array}{l}\text { Yes } \\
\text { Yes } \\
\text { No } \\
\text { Yes } \\
\text { Yes } \\
\text { Yes } \\
\text { Yes } \\
\text { No } \\
\text { Yes }\end{array}$ & $\begin{array}{l}F W \\
F W \\
P \text { Exp UL } \\
P \\
P W \\
F W \\
P \text { Exp } \\
P \text { Exp } \\
P \text { Exp } \\
F W\end{array}$ \\
\hline
\end{tabular}

Table 4. Producing hot water TEOR projects in the United States. 
Table 5. Screening criteria for successful steam floods

\begin{tabular}{|c|c|c|c|}
\hline & Heavy $0 i 1$ & Light $0 i 1$ & $\frac{\text { Alworth Field }}{\text { South Texas }}$ \\
\hline 0il saturation, fraction & 0.40 & - - - & --- \\
\hline 0il saturation $x$ porosity, fraction & $>0.065$ & $>0.1$ & $\cdots$ \\
\hline $0 i 1$ content, bbl/acre- $\mathrm{ft}$ & $<500$ & $>780$ & 1500 \\
\hline Reservoir pressure, psi & $-\cdots$ & $<2,500$ & -.. \\
\hline Net=pay thickness, ft & $>20$ & $>20$ & 15 \\
\hline $\begin{array}{l}\text { Steam injectivity, }(\mathrm{B} / \mathrm{D}) / \text { acre-ft } \\
\text { Permeability } x \text { thickness }\end{array}$ & -.- & $>1.5$ & -.. \\
\hline$\div$ viscosity, md-ft/cp & $>100$ & & --- \\
\hline
\end{tabular}

Table 6. United States TEOR scope.

\begin{tabular}{|c|c|c|c|c|c|}
\hline Company/Field & $\begin{array}{c}\text { Area } \\
\text { (Acres) }\end{array}$ & $\begin{array}{l}\text { Gravity } \\
\text { ('API) }\end{array}$ & $\begin{array}{l}\text { Depth } \\
\text { (ft) }\end{array}$ & $\begin{array}{c}\text { Initiation } \\
\text { Date }\end{array}$ & Success \\
\hline $\begin{array}{l}\text { Chevron/ } \\
\text { Homer Field, LA }\end{array}$ & 40 & 37.0 & 1,250 & 1989 & -- \\
\hline Teapot Dome, WY & 60 & 33.0 & 300 & $10 / 88$ & yes \\
\hline Talcom Field, TX & 5 & 19.0 & 4,300 & $06 / 88$ & -- \\
\hline Garland Field, WY & 20 & 22.0 & 4,250 & $05 / 86$ & no \\
\hline Cat Canyon, CA & 1,000 & 10.8 & 4,400 & $03 / 85$ & yes \\
\hline
\end{tabular}

Numerous models are available in the literature to study steam effects (Marx and Langenheim, 1959; Boberg and Lantz, 1966; Jones, 1976; and Boberg, 1988). In general, steam methods respond best to $0 i 1$ that is $>12^{\circ} \mathrm{API}$, viscosity of 100 to $10,000 \mathrm{cp}$ (at reservoir temperature), and reservoirs with $>50$ md permeability, and $>25 \%$ porosity (Prats, 1978). An important consideration when comparing conventional steam methods with GPGT fluid methods is that in the steam process the steam is at least $80 \%$ quality steam i.e. generated from potable water. The effect of lowering the quality of the feedwater may be significant. The salinity and high concentrations of total dissolved solids (TDS) in GPGT fluids is an important factor in this equation that could significantly affect the economics. 
The distribution of heavy oil resources (Figure 5) shows $42 \mathrm{Bbbl}$ in California, $25 \mathrm{Bbbl}$ in Alaska, $6 \mathrm{Bbbl}$ in Arkansas, Louisiana, and Texas, $5 \mathrm{Bbbl}$ in Wyoming, and $2 \mathrm{Bbbl}$ in other states (Blevins, 1990). Cumulative production of United States heavy oil as of December 31, 1987 was reported at 12.3 Bbbl with $3.3 \mathrm{Bbbl}$ produced by TEOR. The leading United States basins for application of GPGT TEOR to recover medium and heavy oils include the Gulf Coast Basin, the San Joaquin Basin, and the Los Angeles Basin. Totals for these basins are: $8.134 \mathrm{Bbbl}$ of recoverable medium $0 \mathrm{il}$ and $4.239 \mathrm{Bbbl}$ of recoverable heavy oil as indicated in Table 7.

Table 7. Leading basins in the United States for ultimate recovery of light, medium and heavy oil. Source: Department of Energy, 1989.

\begin{tabular}{||l|l|l|l||}
\hline Geologic Province & Light 0il & Medium 0il & Heavy 0il \\
\hline Permian & 24,797 & - & - \\
\hline Gulf Coast & 23,780 & 1,096 & - \\
\hline East Texas & 8,383 & - & - \\
\hline $\begin{array}{l}\text { Louisiana } \\
\text { Offshore }\end{array}$ & 6,242 & - & - \\
\hline North Slope & 6,105 & - & - \\
\hline San Joaguin & 4.533 & 2,108 & 3,815 \\
\hline Los Angeles & 4,069 & 4,930 & 424 \\
\hline
\end{tabular}

An example of a successful steam TEOR project is the Duri field, on the island of Sumatra in Indonesia. This was the largest EOR project in the world in 1990, surpassing the production rate of the Kern River Field in California. In the Duri Field, after three cycles of steam stimulation, additional steam injection proved uneconomical. Steam flooding followed. 0il production is expected to peak at 330,000 bpd by 1993 , with $20 \%$ of the $0 i 1$ being burned at the surface to generate steam for injection, but producing a detrimental environmental effect. 


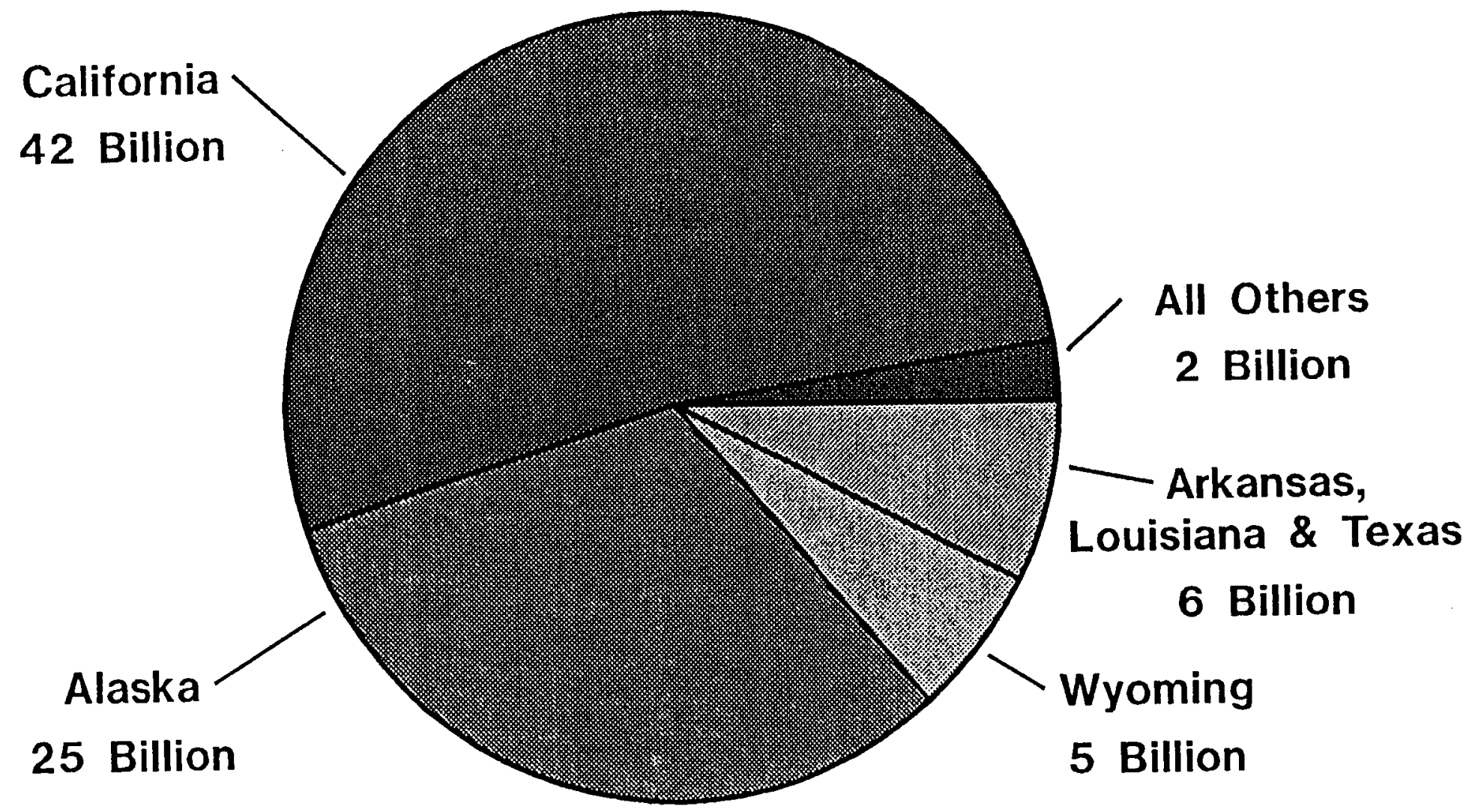

Figure 5. Heavy oil resources in the United States. Source: Kuuskra and Godec, 1987, for DOE, Bartlesville Project Office

(Interstate $0 i 1$ Compact Commission). 
The history, current status, and future outlook of steam flooding in the United States was reviewed by Blevins (1990), division petroleum engineer at Chevron Inc. (Figure 6). As a result of field performance analysis involving the review of project design, production expectations, project implementation, and operating assumptions of many thermal recovery projects, he concluded that steam flooding is a relatively immature technology, not a mature technology as many experts have considered it. An observation of particular note is that "Chevron now places high priority on measuring down-hole parameters and altering operations on the basis of specific In-situ data rather than on computer simulation correlations".

\section{HOT WATER FLOOdING}

Straight hot water injection is less successful than steam flooding because of heat loss and the lowered thermal efficiency due to the comparatively lower energy content (one-third) of heated water compared with steam. Hot water flooding follows the general procedures of water flooding, the conventional secondary recovery method. The principal benefit is the same as other TEOR methods, i.e., the heated water reduces the viscosity of the 0i1. In addition to cost, the disadvantages are similar to those of steam flooding, i.e., the heating of the water by oil or gas and the pumping of the water into the injection well generates extensive pollution and is expensive. Also, the required water supply may not be available. It is important to note that these environmental disadvantages to the hot water method are not relevant within a GPGT context. Technical issues such as scaling problems and changes within the reservoir that are associated with hot water flooding are more relevant to a GPGT TEOR project.

Presently the major producing hot water projects in the United States are all located in California, six in Kern County, two in Bakersfield County, and one in Monterey County. Companies involved are Texaco (4), Arco (3), Mobil (1), and Santa Fe Energy (1). All projects involve sandstone reservoirs 


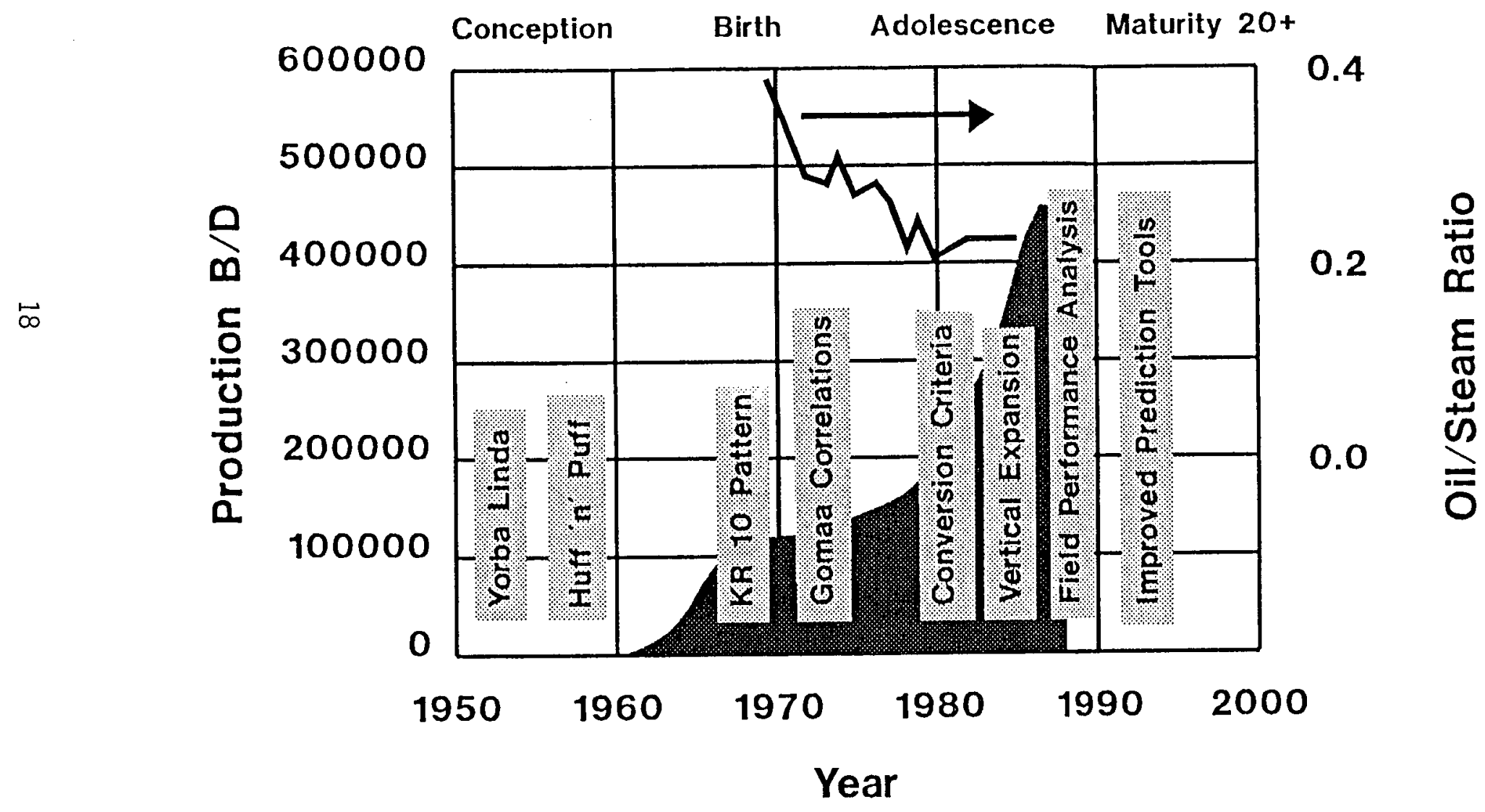

B90 1163

Figure 6. History of steam flooding. Source: Blevins, 1990. 
with porosities of 30 to $40 \%$, and permeabilities of 100 to $4,000 \mathrm{md}$. (most in the $>2,000 \mathrm{md}$. range). Depths range from 200 to 2,200 ft and involve 13 to $14^{\circ} \mathrm{API}$ gravity 011 . Viscosities range from 10 to 24,000 $\mathrm{cp}$, and reservoir temperatures range from 78 to $250^{\circ} \mathrm{F} ; 26$ to $121^{\circ} \mathrm{C}$. Table 4 indicates that a 11 but two are profitable (Moritas, 1990).

An example of a successful hot water TEOR project is Texaco's Midway-Sec. 35 Field in Kern County, California. The project covered 10 acres with six injection wells and 16 producing wells. The pay zone was the Potter Sandstone (35\% porosity, permeability $2,000 \mathrm{md} ., 12^{\circ} \mathrm{API}$ gravity, $38 \mathrm{cp}$. viscosity, and temperature of $200^{\circ} \mathrm{F} ; 93^{\circ} \mathrm{C}$ ). The target reservoir is $1,600 \mathrm{ft}$ deep and the total production was $400 \mathrm{bbl} / \mathrm{d}$, with enhanced production accounting for $220 \mathrm{bbl} / \mathrm{d}$ (Moritas, 1990).

There are probably numerous small but nevertheless successful hot water TEOR projects not reported in the literature. Many are known from the states of North Dakota, Montana, and Wyoming. North Dakota actually reports the greatest occurrence of the use of hot reservoir waters. The oil gravities are relatively high $\left(30\right.$ to $\left.35^{\circ} \mathrm{API}\right)$. Temperatures, although relatively low, are sufficient to improve oil recovery. They range from $230^{\circ} \mathrm{F}\left(110^{\circ} \mathrm{C}\right)$ at the Medora Field, to $240^{\circ} \mathrm{F}\left(116^{\circ} \mathrm{C}\right)$ at the Fryburg Field. Flow rates are from 450 to 10,000 bpd (Amerada Hess, private communication). In the Madison Formation of North Dakota produced water with a temperature of 230 to $250^{\circ} \mathrm{F}$ (110 to $121^{\circ} \mathrm{C}$ ) is mixed with surface water and re-injected into the same formation. This is considered to be secondary recovery. A 10 to $15 \%$ increase in overall production is attributed to using this method. In the past year several new projects using this technique have been started. Produced water is approximately two to one over production, perhaps 200,000 bpd over the entire state (Chuck Kock, North Dakota Geologic Survey, 0 il and Gas Division, private communication).

Projects similar to those occurring in North Dakota are reported from other regions. In Canada, Alberta Energy began producing the South Jenner Manville J. Pool Field in 1989 with one injection well and three producing wells covering 2 acres. In Germany four hot water recovery projects are 
reported in the Emlichheim Field of Lower Saxony. The fields range from 64 to 82 acres each, using 1-2 injection wells, and up to nine producing wells. The target reservoir is a Valenginian sandstone with 30\% porosity and permeability of $6,000 \mathrm{md}$. at a reservoir temperature of $95^{\circ} \mathrm{F}\left(35^{\circ} \mathrm{C}\right)$. Depths range from 2,300 to $2,550 \mathrm{ft}$. The oil is $24.5^{\circ} \mathrm{API}$ gravity with a viscosity of $175 \mathrm{cp}$. Initial production ranged from 85 to $230 \mathrm{bbl} / \mathrm{d}$ with the same range from enhanced production. All projects were evaluated as successful and profitable (Moritas, 1990).

A project of particular importance is that reported from the Schoonbeck Field, in Holland in which steam and hot brine were successfully used for TEOR.

A generalization for a successful hot water TEOR project includes a target reservoir with the following characteristics.

$\begin{array}{ll}\text { High porosity } & 25 \text { to } 25 \% \\ \text { High permeability } & >1,000 \mathrm{md} \\ \text { Shallow depth } & <3,000 \mathrm{ft} \\ \text { 0il gravity } & >12^{\circ} \mathrm{API} \\ \text { Injection water } & >200^{\circ} \mathrm{F} \\ \text { Viscosity } & 50 \mathrm{to} 8,000 \mathrm{cp} \\ \text { Reservoir thickness } & >30 \mathrm{ft}\end{array}$

The minimum oil saturation necessary for a TEOR project to be successful is variable. The limit is simply determined by whether or not the project is considered profitable. In some tests 10 to $12 \%$ saturation has been regarded as a minimum.

The fact that a reservoir is heterogeneous may lead to preferential channelling and early breakthrough at the production well. This would necessitate shutting in or selectively plugging the well at the expense of production. Well number in the flooding pattern should be minimal to reduce the likelihood of channelling, e.g., line drive, hexagonal, or octagonal. 


\section{Characteristics of the GPGT Resource}

Geopressured reservoirs are a normal phase of basin evolution, and present geopressured basins occur in many locations throughout the world and in many states in the USA, as seen in Figures 7 \& 8 (Fertl et al., 1976). Overburden pressure originates from the combined weight of the formation rock and the fluids (water, oil and gas) in the pore space overlying the formation of interest (Fertl \& Chilingarian, 1977, Timko \& Fert1, 1971). The overburden pressure generally increases uniformly with depth by a gradient of about $1.0 \mathrm{psi} / \mathrm{ft}$ of depth. The probable maximum overburden gradient, based on worldwide experience may be as high as $1.35 \mathrm{psi} / \mathrm{ft}$. Hydrostatic pressure is a result of the weight of interstitial fluids and is equal to the product of the unit weight of the fluid and the vertical height. The hydrostatic pressure gradient is a function of the concentration of dissolved solids and gases in the column and the varying temperature gradient. The hydrostatic pressure gradient for fresh water is $0.433 \mathrm{psi} / \mathrm{ft}$. Abnormal formation pressures are defined as pressures above or below the expected hydrostatic pressure for a particular depth. Geopressured reservoirs are overpressured. A seal is necessary for a formation to be abnormally pressured, because without a seal, the pressure would be equalized to hydrostatic (Bradley, 1975). Pressures may approach lithostatic pressure and have actually been measured up to $1.05 \mathrm{psi} / \mathrm{ft}$ in the Gulf Coast area (Figure 9).

Deep geological formations located in the northern Gulf of Mexico contain large reservoirs of hot brine under abnormally high pressure and temperature. This geopressure zone can be detected and evaluated by the interpretation of seismic data, drilling data, and well log data. By definition a geopressured reservoir has a pressure gradient exceeding the normal hydrostatic gradient, which, in the Gulf Coast Basin, is $0.465 \mathrm{psi} / \mathrm{ft}$. A pressure gradient of $0.465 \mathrm{psi} / \mathrm{ft}$ assumes a water sal inity of $80,000 \mathrm{mg} / \mathrm{L} \mathrm{NaCl}$ at $25^{\circ} \mathrm{C}\left(77^{\circ} \mathrm{F}\right)$. 


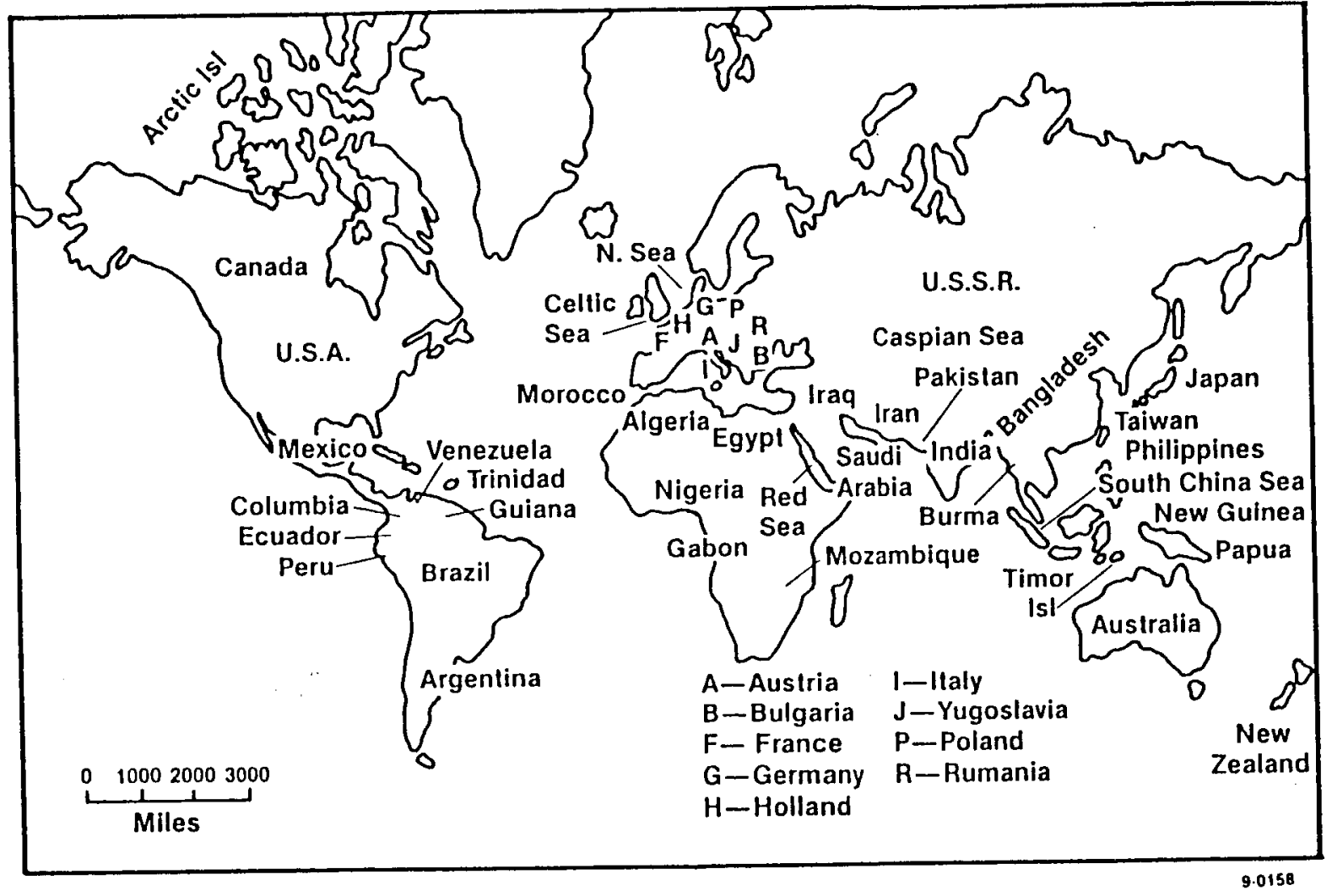

Figure 7. Worldwide occurrence of abnormal formation pressure. Source: Fertl et al., 1976. 


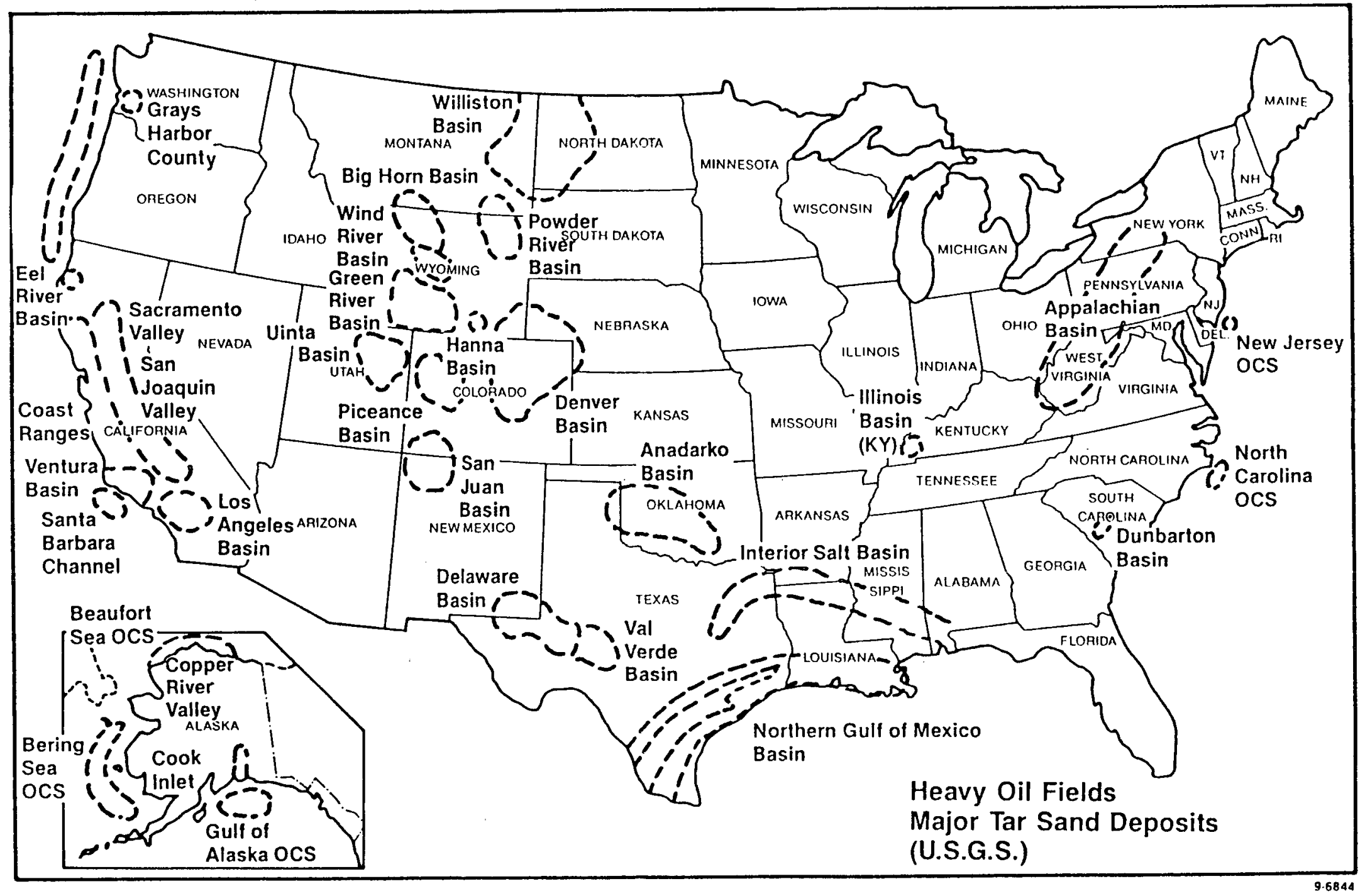

Figure 8. Location of geopressured basins, heavy $0 i 1$ and tar sands in the United States. Strongin (1981) and Myers.

(private communication, USGS, 1989) 


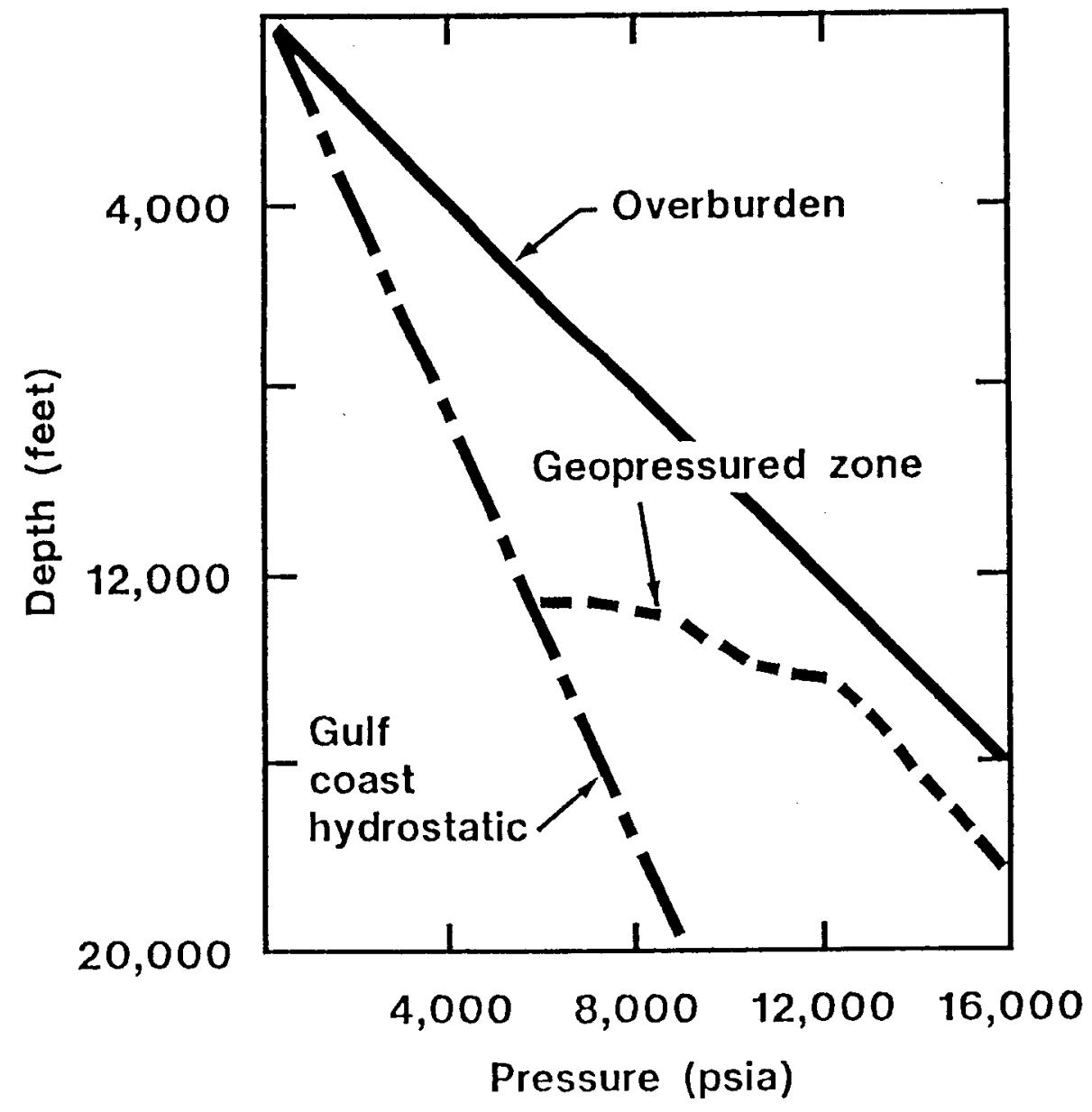

B90 0242

Figure 9. Depth - pressure relationship of the geopressured zone. Source: Bradley, 1975. 
Estimates of the energy potential of the GPGT reservoirs range as high as 180,000 quadrillion BTUs (quads) (EPRI, personal communication). The U.S.G.S. has estimated that there are 5,700 quads of accessible gas and 11,000 quads of thermal energy in the onshore Gulf Coast reservoirs without regard to economics (Wallace et al., 1979; Eaton et al., 1988).

In recent years, the DOE has sponsored the Geopressured-Geothermal (GPGT) Research Program and the investigation of three GPGT well sites operated under the direction of the Idaho Operations Office (DOE) to assess and evaluate the technical and production characteristics of this undeveloped resource (Figure 10 and Negus de-Wys 1989a, b). The we1ls, brine, and reservoir characteristics relevant to the GPGT program are provided in Table 8 . The three major sites studied by DOE are important examples of the source reservoirs for GPGT fluids to be used in TEOR.

Table 8. Wells, brines, and reservoir characteristics for the three DOE GPGT wells. Source: Eaton 0il Company, DOE program reports, Geothermal reviews, University of Texas at Austin, Louisiana State University, and INEL

\begin{tabular}{|c|c|c|c|}
\hline & GLADYS $M^{c}$ CALL & PLEASANT BAYOU & HULIN ${ }^{2}$ \\
\hline Depth, ft. & 15,831 & 16,465 & 21.546 \\
\hline Max. flow rate, bbd & 40,000 & 25,000 & 15,000 \\
\hline BHP, psia & 12,784 & 9,800 & 18,500 \\
\hline FWP, psia & 2,000 & 3,000 & $3,500^{3}$ \\
\hline $\mathrm{BHT},{ }^{\circ} \mathrm{F}$ & 298 & 302 & 360 \\
\hline $\mathrm{FWT},{ }^{\circ} \mathrm{F}$ & 268 & 292 & 330 \\
\hline Gas/water ratio, scf/bbl & 27 & 24 & 34 \\
\hline Methane, $\%$ of gas & 85 & 85 & 93 \\
\hline $\mathrm{CO}_{2}, \%$ of gas & 9.7 & 10.0 & 4.0 \\
\hline Reservoir size, $8 b b l s^{1}$ & 4 & 8 & 14 \\
\hline TDS, $\mathrm{mg} / \mathrm{L}$ & 95,000 & 127.000 & 195,000 \\
\hline Chlorides, $\mathrm{mg} / \mathrm{L}$ & 57,000 & 70,000 & 115,000 \\
\hline
\end{tabular}




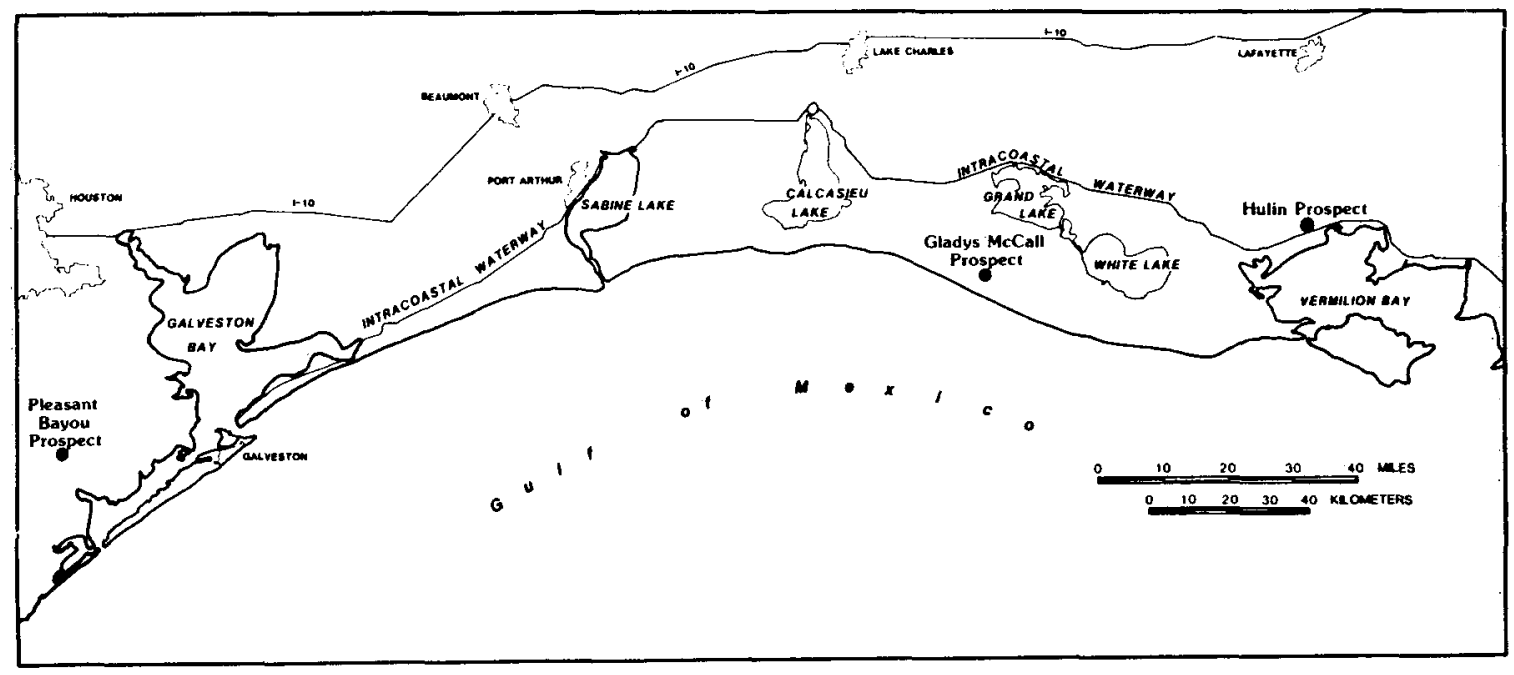

Figure 10. Map showing the location of the three current GPGT prospects: Gladys McCal1, Hulin, and Pleasant Bayou. Source: John et a1., 1990

The unique characteristic of the GPGT fluids of significance to TEOR projects include the following:

high temperatures,

high pressures,

high flow rates, and

high sodium ( $\mathrm{Na}$ ) content in the brine.

The Gladys McCall Site, Louisiana

Data from the Gladys McCall reservoir testing and analysis represent the most comprehensive information available on long-term production and depletion of a GPGT reservoir. This design well was drilled in 1981 to $16,510 \mathrm{ft}$, plugged back to $15,831 \mathrm{ft}$, and completed with 5 inch production tubing. After initial testing of a deeper sand zone, the well was perforated from 15,160 to $15,470 \mathrm{ft}$ in Sand Zone No. 8. Testing of this zone was initiated in October 1983, and the well was shut in 0ctober 1987. Initial static reservoir conditions were $12,784 \mathrm{psia}$ and $298^{\circ} \mathrm{F}\left(148^{\circ} \mathrm{C}\right)$. Brine temperatures at the surface remained relatively constant at $268^{\circ} \mathrm{F}\left(131^{\circ} \mathrm{C}\right)$ during most of the testing. Gas content in the brine ranged from 22.9 to $29.7 \mathrm{scf} / \mathrm{bbl}$, depending on the separator pressure. Average chlorinity of the brine was $57,000 \mathrm{mg} / \mathrm{L}$ and total dissolved solids content was $95,000 \mathrm{mg} / \mathrm{L}$ (IGT, private 
communication, 1988). During the testing period, production rates ranged from about 10,000 to $30,000 \mathrm{bpd}$, with an average production rate of about 17,000 bpd (Figure 11). A total of over 27 MMbbl brine with $23 \mathrm{scf} / \mathrm{bbl}$ of gas were produced during this period; water was reinjected into a shallow saline aquifer without difficulty, suggesting that damage to the injection target reservoir during TEOR may not be a severe problem. Based on the performance during testing, the reservoir volume was estimated to be 4 Bbbl (UT at Austin). Geological and rock mechanical studies estimated the reservoir parameters of permeability, compressibility, etc. Reservoir calculations using these parameters indicated that the well could produce 40,000 bpd for 5 years with an estimated final wellhead pressure of 1,300 psi. This projection may be optimistic, in view of the actual performance of the well during the testing period. During 1986, for example, the production rate declined from 31,000 to 25,000 bpd while the first-stage separator was maintained at 1,000 psia. Projections of reservoir performance made by S-Cubed Inc., indicated that the well could sustain a production rate of 25,000 bpd for about 7 years with a wellhead pressure of 1,000 psia at the end of the that time. Anticipating that the well could sustain this production rate for 10 years is considered optimistic; anticipating 20 years is considered unrealistic. Similar projections for an estimated production rate of 30,000 bpd indicated that the well could sustain this flow for 4 to 5 years before the wellhead pressure dropped below 500 psia. It is important to note that analyses of pressure buildup data obtained since the well was shut-in indicate that the recovery is better than anticipated from the simulations.

\section{The Pleasant Bayou Site, Texas}

The first design well drilled at the Pleasant Bayou site encountered completion problems that precluded its use as a production test we 11. Pleasant Bayou \#2 was drilled to a depth of $16,465 \mathrm{ft}$, perforated in a Frio sand from 14,644 to $14,704 \mathrm{ft}$, and completed with 5-1/2 inch 0.D. production tubing. Structural failures in the production tubing occurred on two separate occasions after the well was drilled in 1979, necessitating expensive reworking operations. Initial static reservoir conditions were 11,168 psi and $302^{\circ} \mathrm{F}\left(150^{\circ} \mathrm{C}\right)$. The brine temperature at the surface under production was about 


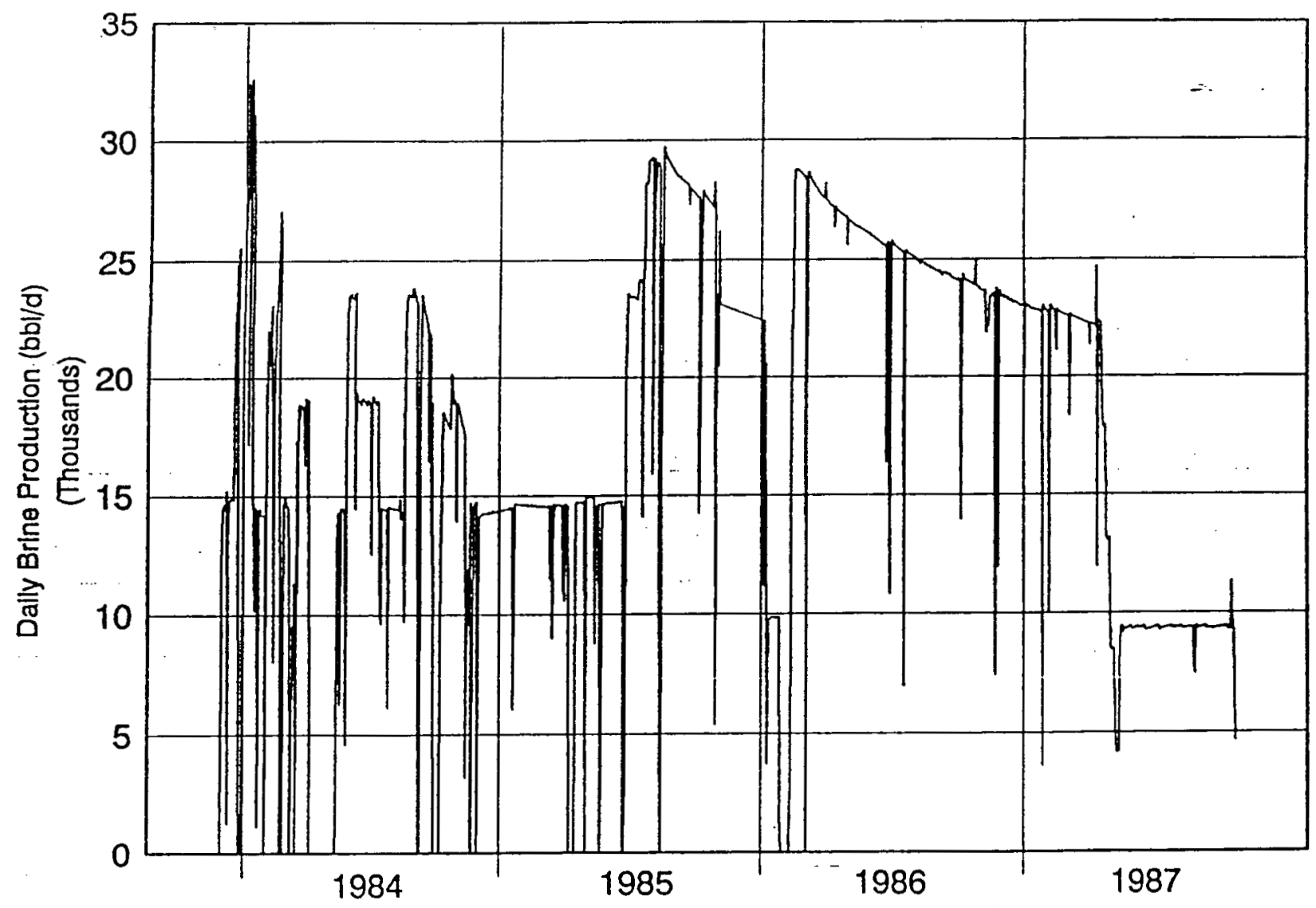

Figure 11. Graph showing the daily production of brine during the 1984-1987 period of testing at Gladys McCall Well (data from Eaton Operating Company, 1991) 
$292^{\circ} \mathrm{F}\left(144^{\circ} \mathrm{C}\right)$. The brine salinity averages $70,000 \mathrm{mg} / \mathrm{L}$ and the TDS $127,0000 \mathrm{mg} / \mathrm{L}$ and the gas produced at a separator pressure of $800 \mathrm{psi}$ is $24 \mathrm{scf} / \mathrm{bbl}$ (Eaton 0il Company, operating reports, 1989). Analyses of the gas indicate that it is about $85 \%$ methane, $6 \%$ ethane and higher components, and the remainder $\mathrm{CO}_{2}$. Early estimates of reservoir volume based on initial testing of the well were on the order of 2 Bbbl. Initial projections of brine production rate suggest the well could produce 20,000 bpd for 6 to 7 years and 30,000 bpd for 3 to 4 years. More recent projections (Riney, 1988) indicate the flowing wellhead pressure would decline to about 1,200 psia after 5 years of production at 20,000 bpd. Since June 1988, the flow rate has been 18,000 to 20,000 bpd. Recent reservoir size estimates based on geological studies and reservoir modeling revised the volume upwards to 8 Bbbl (Riney, private communication, 1989). This revision may reflect recharge and fault leakage. Improved reservoir size estimates may allow better estimates of reservoir performance. It should be noted that production from the well is 1 imited to 20,000 bpd because of sanding problems that occur at brine production rates above 22,000 bpd. Sand production could be a short or long term problem and is currently one of the primary considerations in controlling well operations.

The Hul in Site, Louisiana

The Hul in Well was drilled and completed to a depth of $21,546 \mathrm{ft}$ by Superior 0il Company in 1978. After 19 months of gas production, the wellhead pressure had declined to $1,000 \mathrm{psi}$. Subsequent efforts to restore production resulted in a packer or tubing failure and the well was abandoned. It was subsequently transferred to DOE to test GPGT zones above the gas production zone. Well log interpretations indicated that the well penetrated a massive geopressured zone from 20,010 to $21,120 \mathrm{ft}$. The we11 was reworked by DOE and the first test zone was perforated in late 1988 . The DOE program initiated short term flow testing in December 1989. These tests resulted in preliminary estimates of $34 \mathrm{scf} / \mathrm{bbl}$ and a 7,200 psia shut-in wellhead pressure. These data are from the first three perforation zones, two at the base and one at the top of the $500 \mathrm{ft}$ thick sand that is the major production target.

Estimates of resource parameters based on well log analysis and data obtained during reworking indicated a reservoir temperature of 350 to $375^{\circ} \mathrm{F} ; 177$ to $\left.191^{\circ} \mathrm{C}\right)$, a brine salinity of $115,000 \mathrm{mg} / \mathrm{L}$ and TDS of $195,000 \mathrm{mg} / \mathrm{L}$ with a gas 
content of about $50 \mathrm{scf} / \mathrm{bbl}$ (Meahl, private communication, 1989). Occurrence of free gas was suggested from well log interpretations (Dunlap, private communication, 1989). However, thus far the limited testing has not shown evidence of any free gas. Reservoir volume estimates as high as 14 Bbbls were calculated based on probable fault block size and expected porosity (geological studies at UTA and Riney, private communication, 1989). After developing a new structure map using an additional 22 miles of seismic data, Louisiana State University revised the reservoir volume estimate to a conservative $1 \mathrm{Bbbl}$ on the basis of faults and porosity. However, this should be viewed as a minimum since the reservoir appears open to the southwest with no identified bounding faults. Well performance may help to define the reservoir volume.

The Hulin Well provides an example of using a reworked oil or gas well, rather than drilling a new GPGT well. The production is 1 imited to 15,000 to 18,000 bpd by the well depth and tubing size restrictions. This wellbore limitation would be typical for depleted wells that are recompleted for GPGT production. It is unreasonable to assume 40,000 bpd production from an existing reworked well even with excellent reservoir conditions. 


\section{THERMAL ENHANCED OIL RECOVERY \\ USING GEOPRESSURED - GEOTHERMAL FLUIDS}

\section{Concept and Methodology}

The concept of GPGT TEOR is very simple. Geopressured-geothermal reservoirs contain high pressure, high temperature, and usually, gas saturated brine. The concept is to use these fluids to recover oil from a shallow reservoir found structurally above the geopressured-geothermal reservoir. The high pressure of the GPGT reservoir compared with the low pressure of the target reservoir allows moving the fluid to the target reservoir simply by pressure differential. The high temperature of the brine will heat the oil in the target reservoir and thus reduce its viscosity to a level where it can be pumped. As noted earlier, viscosity reduction techniques have made the greatest contribution to EOR when compared with other tertiary recovery processes (Figure 12) especially when considering the efficiency of recovering heavy oil (Figure 13). The explanation is seen in the temperature - viscosity - oil gravity relationships. Thus, the advantages of using the GPGT fluids in TEOR are as follows:

- A source of high temperature water.

- Internal drive method determined by the pressure differential that will pump the GPGT brine hydraulically into the target reservoir.

- No emissions from the burning of crude oil.

- $\quad$ No outside use of fresh water.

- Possible use of natural gas from the GPGT fluids to drive surface equipment. 


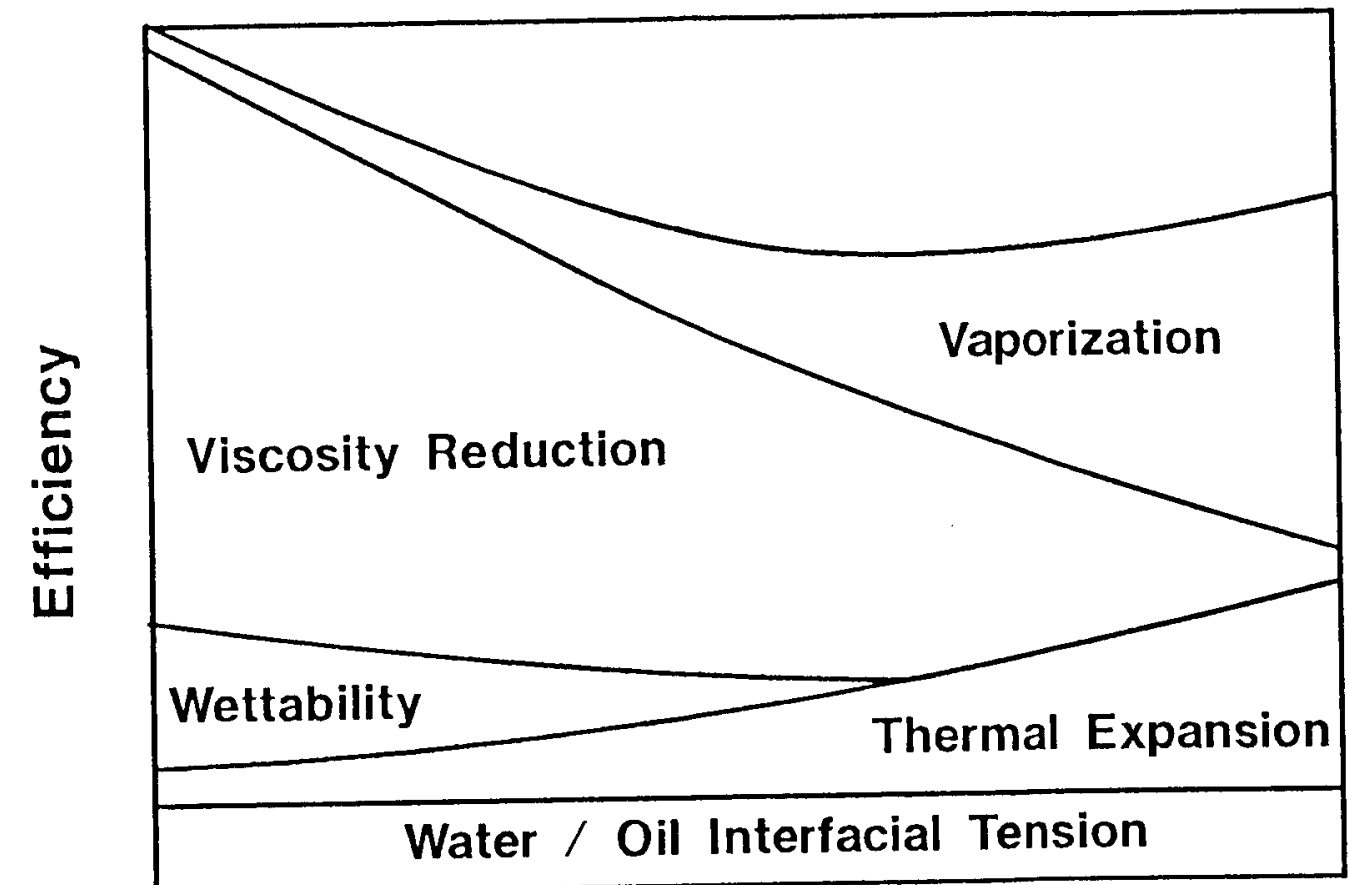

\section{Decreasing Density}

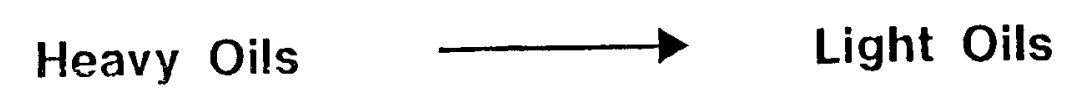

Figure 12. Contribution of viscosity reduction to the efficiency of heavy oil recovery. Source: Belvins, 1990. 


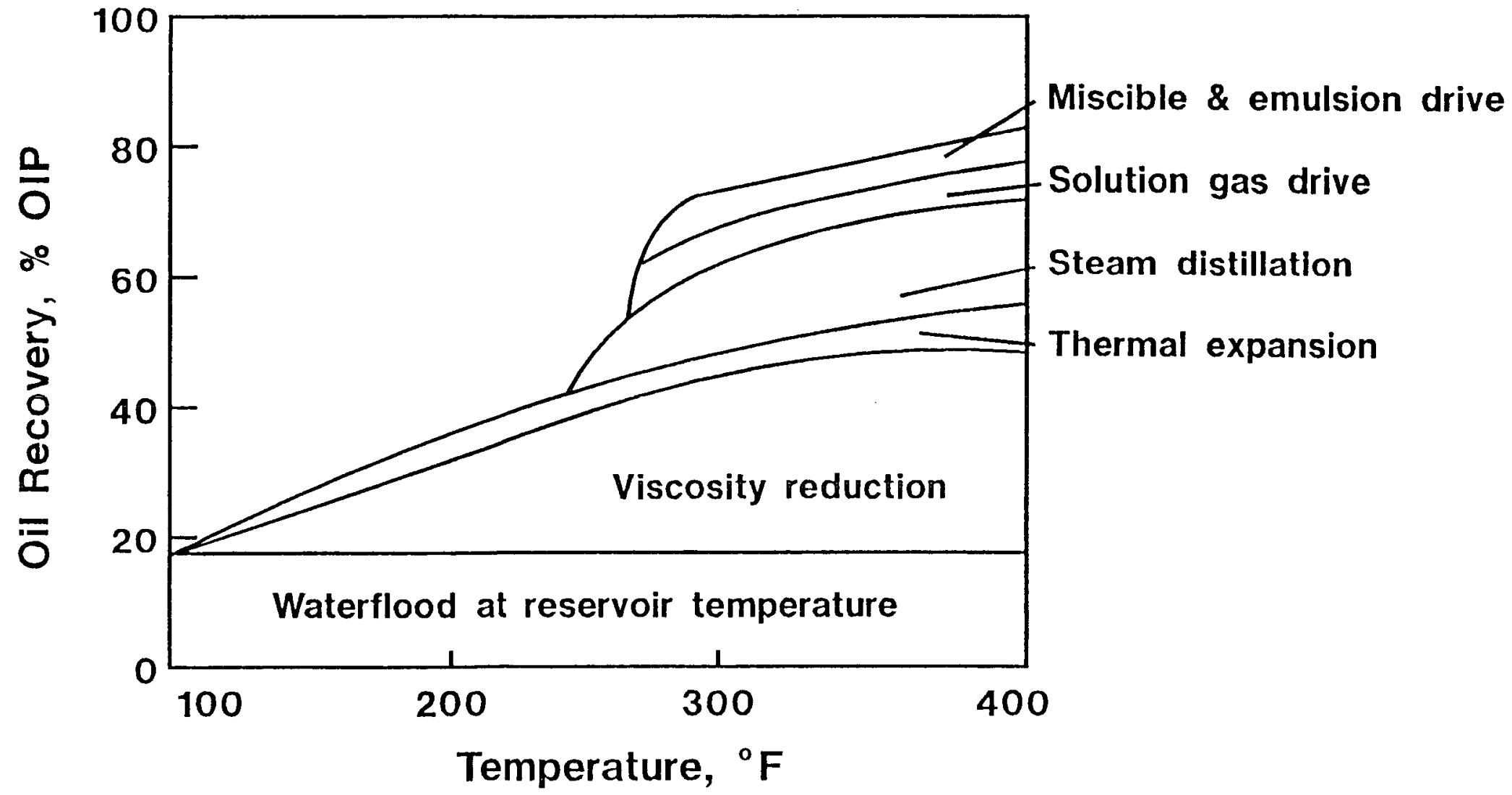

Figure 13. Contribution of viscosity reduction to $0 i 1$ recovery. Source: Belvins, 1990. 


\section{Process Feasibility}

Three steps are important in proving the GPGT TEOR technology.

The first step in proving the technology is a collocational analysis to find suitable GPGT and target reservoirs. Analyses are being undertaken by The University of Texas at Austin for Texas heavy oil fields; and, by Louisiana State University for Louisiana heavy oil occurrence. A test field (Alworth Field) has been proposed for Texas and is available as part of an industry cost-sharing proposal with Fanion Production Company. The target reservoir is the Cole Sandstone, at a depth of $1,000 \mathrm{ft}$. The field is presently marginally economical and is currently producing about $20 \mathrm{bpd}\left(8^{\circ} \mathrm{API}\right)$ from five producing wells. As shown in Figure 3 , the viscosity of $18^{\circ} \mathrm{API}$ gravity oil can be reduced from about 100 centipoise at a temperature of $90^{\circ} \mathrm{F}\left(32^{\circ} \mathrm{C}\right)$ to 10 centipoise if it is heated to $200^{\circ} \mathrm{F}\left(93^{\circ} \mathrm{C}\right)$. The shallow location of the reservoirs in this field, its simple structure, and the availability of industry cost-sharing provide good conditions for the completion of an successful test of a TEOR project using GPGT fluids.

The second step is to assess the technological problems involved in hot fluid injection as they pertain to the utilization of the GPGT resource in TEOR. This requires a knowledge of the chemical and thermodynamic properties of both the target reservoirs, rock matrix and fluid content, and the GPGT brine. Because of the specificity of the reactions, each situation may need to be treated differently. Additional research in this area should go hand-in-hand with field testing. The well in the target reservoir must be designed to handle the thermal stress (Spillette, 1965; Leutwyler and Bigelow, 1965; Lauwerier, 1955; Kimmell et al., 1989) and the equipment must be able to handle the pressure, temperature, and flow rate as well as the water quality. 
In steam and water flooding, the quality of feedwater dictates the type of treatment it undergoes. The GPGT fluid represents extreme conditions from the viewpoint of conventional TEOR feedwater.

Subsurface waters increase their TDS and chloride content with increasing depth in an attempt to maintain thermodynamic equilibrium during progressive burial. "Maintenance of equilibrium between brine and quartz, feldspars, sheet silicates, and carbonates appear to be particularly important factors which influence brine composition. Exchange between brine and host sediments profoundly alters the isotopic composition of these waters" (Hanor, 1983). The normal desired characteristics for the feedwater used in steam and hot water flooding are given by Burger et a1. (1985) as follows:

$<5 \mathrm{mg} / \mathrm{L}$ suspended solids, organics, dissolved gases, magnesium or calcium ions, i.e. zero hardness, and $<0.4 \mathrm{mg} / \mathrm{L}$ iron.

These conditions are impossible to meet in GPGT fluids. Typical chemical compositions of the GPGT brines are given in Table 8. Upgrading of the water for suspended solids, organics, iron and hardness are difficult. The brines are saturated with both methane and carbon dioxide and are highly buffered with bicarbonate (Schaeper, et. a1., 1989). Gas in solution can probably be produced without deleterious effect on the useful aspects of the GPGT fluid. Besides $\mathrm{CO}_{2}$ other gases include $\mathrm{N}_{2}$, $\mathrm{CH}_{4}, \mathrm{H}_{2}, \mathrm{Ar}$, and higher saturated hydrocarbons. These are less soluble than $\mathrm{CO}_{2}$ by a large factor and this greatly effects flash initiation (bubble point) and therefore, scaling (Michels, 1981). Hanor (1981) preliminarily evaluated which reactions were most likely if GPGT fluids are injected back into the ground. 
Some geopressured reservoirs have low total dissolved solids, e.g., the Upper Wilcox Formation in the Rio Grande embayment. These fluids would be more desirable for a TEOR project.

A major question relating to the second step concerns the reactions within the target reservoir rock matrix. Specifically, will the use of GPGT brine result in formation damage such as plugging by causing irreversible changes in the rock composition? The possible alternative is that the injection of the brines will actually improve permeability and porosity (Figure 14). Because clays have a high cation exchange capacity they have an affinity for water and some polar compounds in crude oil. The adsorption equilibrium of materials in contact with the clay minerals may be modified when brine bathes the clay. The result may be a change in porosity and/or permeability, wettability, and oil saturation. Various mineral species may precipitate or dissolve according to the pressure, temperature and chemical composition of the GPGT fluids (Grim, 1968; Boon, 1977). Again this may result in porosity and/or permeability change. Figure 15 illustrates the three major kinds of porosity that occur in subsurface reservoirs.

It is advantageous if the target reservoir has intergranular porosity and disadvantageous if it is microporosity. This characteristic can be readily determined with modern SEM MICROPROBE techniques. A positive feature may be that silica dissolution and the decomposition of other minerals (siderite, pyrite) can take place at the temperatures possessed by GPGT fluids (Reed, 1980; Aksinat, 1983; Sanuquet \& Corre, 1982). This may enhance porosity and/or permeability especially by reopening the original intergranular porosity. The natural occurrence of this phenomenon is noted by Hart et al. (1989) in the deep productive Robulus L Sand, Offshore Louisiana. 
HIGH $\Phi$ RESERYOIR

WITH BY-PASSED OIL

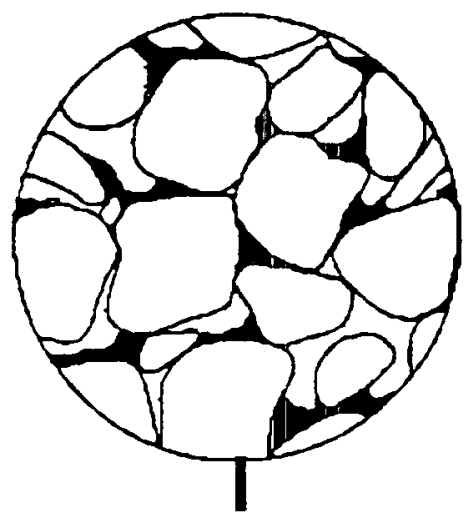

GPGT TEOR

FORMATION / BRINE COMPATIBILITY?
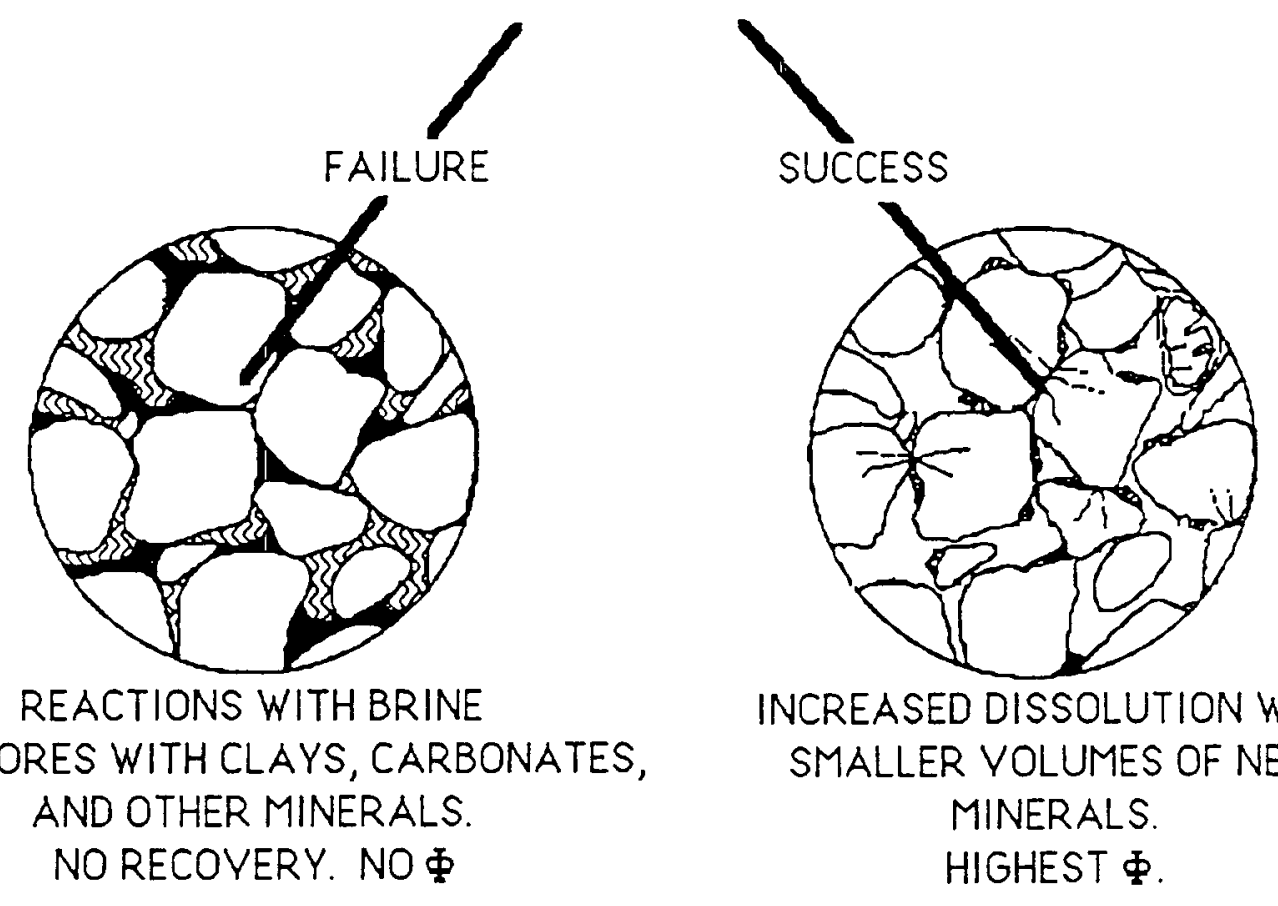

INCREASED DISSOLUTION WITH SMALLER YOLUMES OF NEW MINERALS. HIGHEST $\Phi$.

Figure 14. Alternative reactions in target reservoirs with injection of GPGT brines. Source: Ferrell, personal communication, 1990. 


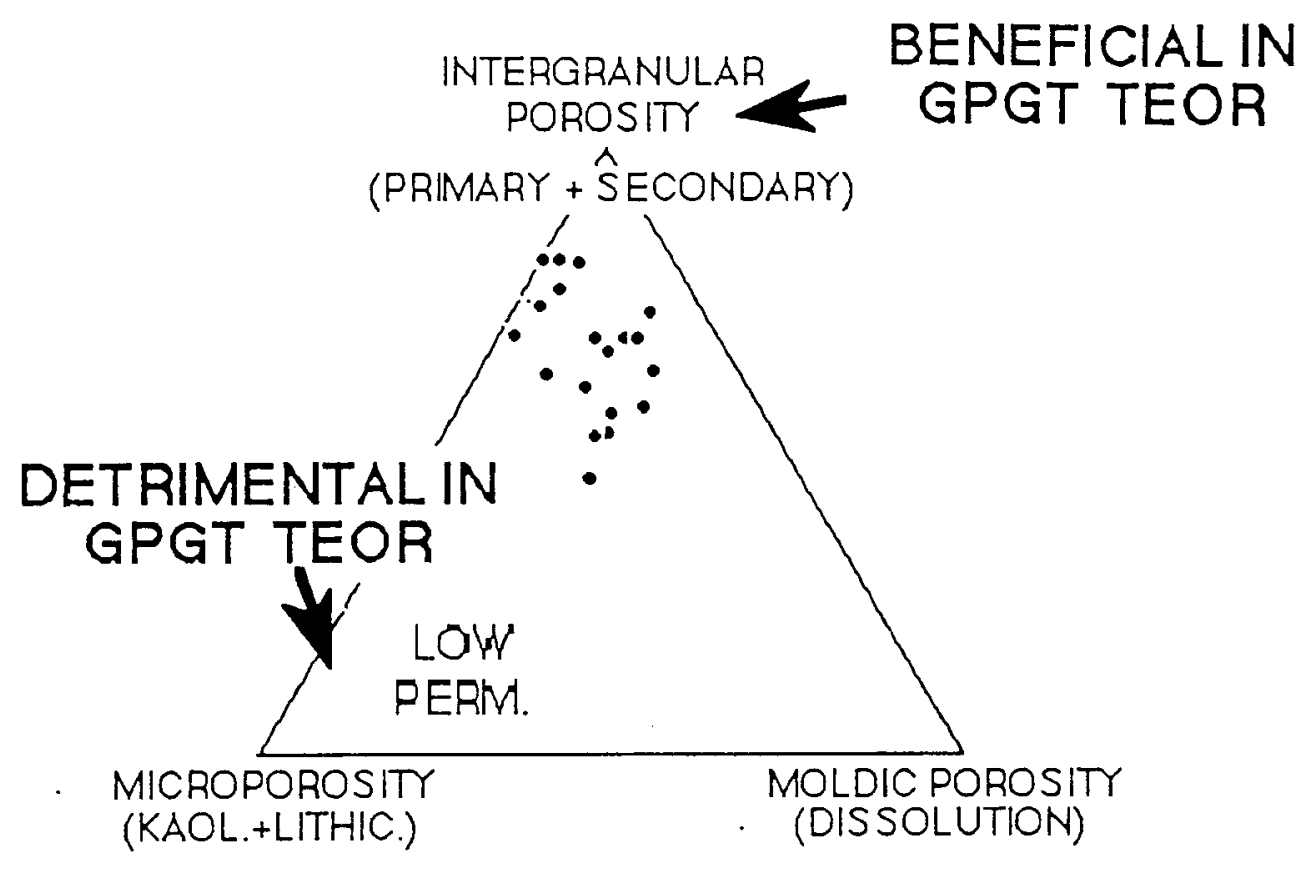

Figure 15. Triplot showing the three major kinds of porosity occurring in detrital target reservoirs. Source: Ferrell, personal communication, 1990.

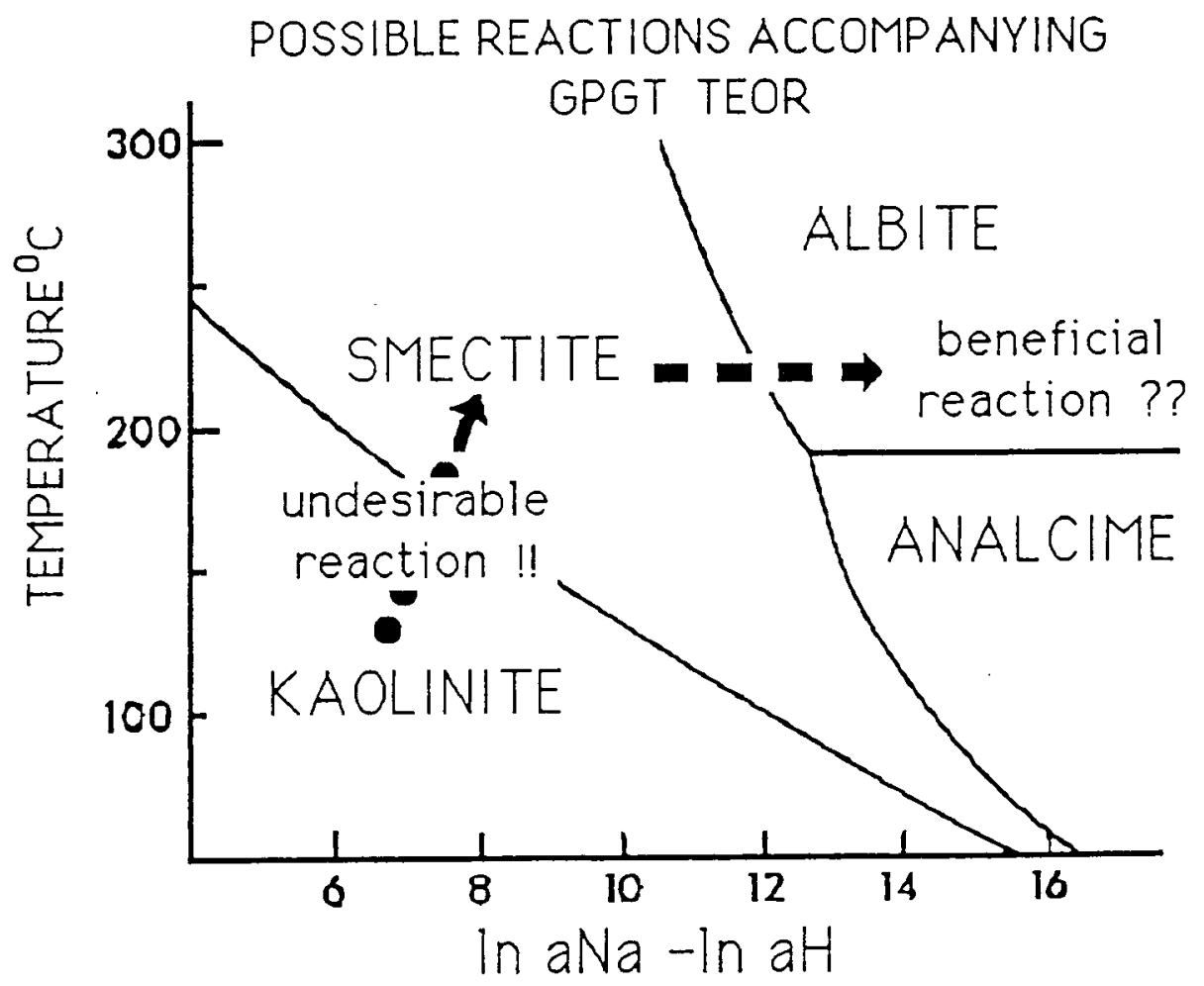

Figure 16. Possible mineral reactions accompanying GPGT TEOR. Source: Ferrell, personal communication, 1990.

"In a" = log-normal activity of $\mathrm{Na}$ and $\mathrm{H}$. 
A general review of artificial digenesis occurring during TEOR was provided by Hutcheon (1984). He described the importance of original composition and mineral distribution within the sands, the temperature and time of exposure to elevated temperatures, and the water-to-rock ratio as the important factors controlling the extent of mineral alteration. The mineral reactions may affect oil recovery by modifying porosity and permeability, but data are not readily available to assess whether the changes are beneficial or detrimental. With GPGT fluids the changes could be pronounced because of their high salt content.

Some of the phase relationships expected under chemical equilibrium conditions are presented in Figure 16 . In an isochemical system containing kaolinite one can predict that an increase in temperature would favor conversion of kaolinite to smectite, a major source of pore-clogging in water sensitive reservoirs. Analcime, or albite, might be produced from smectite by increasing the $\mathrm{Na} / \mathrm{H}$ activity ratio. Converting smectite to analcime (normally a denser mineral) could increase the porosity and permeability of a sandstone. In many systems, hot water dissolves large quantities of silica thereby enhancing porosity and permeability. Such predictions can only be used qualitatively, because the actual pathway of a reaction is a product of incompletely known kinetic and mass transfer effects. Laboratory tests are essential to understanding when TEOR fluids produce beneficial changes in the mineralogy and permeability of reservoirs.

Perhaps the most likely problem will be scaling within the pore spaces of the target reservoir. This could severely reduce permeability and porosity, perhaps within days of commencing production. $\mathrm{CaCO}_{3}$ in the GPGT aquifer is in thermodynamic equilibrium with the brine. Pressure will be reduced as the GPGT fluid enters the target reservoir and this will cause supersaturation of the brine with $\mathrm{CaCO}_{3}$. This may precipitate 
onto the mineral grains clogging up the porosity and reducing the permeability. The question of whether or not flashing of $\mathrm{CaCO}_{3}$ will occur is uncertain. However, fluids richer in $\mathrm{CO}_{2}$ are more sensitive to $\mathrm{CaCO}_{3}$ deposition in confined spaces (Michels, 1981), and the effect may be to fill porosity near to the well bore in the target reservoir. The use of inhibitors, based on the detailed brine chemistry, may be economically feasible (Tomson, 1982). In reservoirs with high porosity and permeability, scaling may not be a major problem.

A positive factor is that injection wells for GPGT brines have been used in coastal regions of the Gulf Coast Basin for many years. Moreover, the continuous use of the injection wells at the DOE Gladys MCCall site and the DOE Pleasant Bayou site suggest that the problem should not exist.

Brine/Hydrocarbon Interaction - The changes in the physical and chemical properties of hydrocarbons depend principally on the temperature of the reaction and the types of hydrocarbons present. However, those reactions of any significance (dehydrogenation, cracking, and condensation) take place above the temperatures at which the GPGT fluid is injected. Dehydrogenation is preferentially a $C_{2}-C_{5}$ phenomenon and results in the formation of a carbon residue at temperatures above $400^{\circ} \mathrm{C}\left(752^{\circ} \mathrm{F}\right)$. Condensation occurs at even higher temperatures $\left(700\right.$ to $800^{\circ} \mathrm{C} ; 1292$ to $\left.1472^{\circ} \mathrm{F}\right)$. Cracking occurs at temperatures above $300^{\circ} \mathrm{C}\left(572^{\circ} \mathrm{F}\right)$. A11 these processes require temperature in excess of those found in geopressured-geothermal reservoirs 250 to $500^{\circ} \mathrm{F}\left(121-260^{\circ} \mathrm{C}\right)$. Laboratory studies indicate changes in the crude oil composition occur at temperatures of 200 to $350^{\circ} \mathrm{C}\left(392\right.$ to $\left.662^{\circ} \mathrm{F}\right)$ when the heating occurs for a prolonged period: both $\mathrm{CO}^{2}$ and $\mathrm{H}_{2} \mathrm{~S}$ may be produced as pollutants in the presence of water aqua-pyrolysis (Monin and Audibert, 1984; and Aksinat, 1983). The conclusion is that brine - hydrocarbon interactions need not be considered. 
The third step concerns production of the GPGT fluids. The work of Hanor \& Bailey (1983) shows the variations in temperature and Figure 17 geostatic ratio ( $p s i / f t)$, salinity of pore water fluids, and hydraulic head for the south Louisiana GPGT zone (Figures 17, 18 , \& 19).

Clearly, temperature and hydraulic head are not a problem. As noted above, the chemistry of the pore waters may be. Early attempts to develop the GPGT fluid technology in the 1980's encountered problems due to the precipitation and deposition of scale in the producing wells, and corrosion of equipment (Feber, 1979). The DOE GPGT program provided an economic analysis of brine utilization and has shown that production of the fluid is economically feasible (Plum et al., 1989). Kerrisk (1981) notes that the problem is complicated because the chemistry of GPGT brines is site specific. Methods for controlling scale are known but may not be cost effective. Johnson (personal communication) notes that $\mathrm{CaCO}_{3}$ scaling can be controlled in GPGT brines with phosphate inhibitors. The publication of Michels (1981) provides a useful insight into the whole area of geothermal engineering for GPGT fluid utilization. 



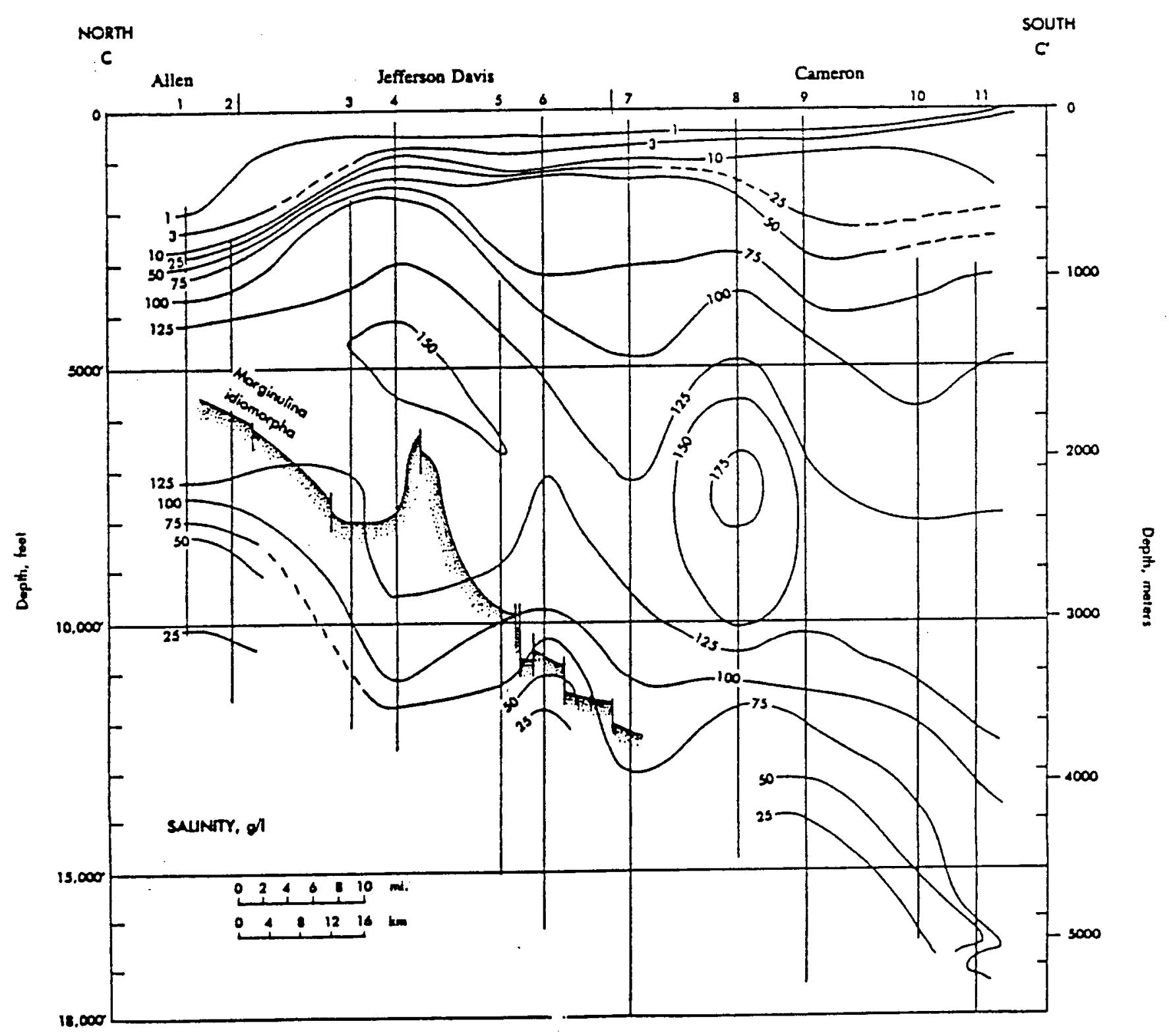

Figure 18. Salinity of pore waters $(g / 1)$ calculated from electric logs, Louisiana Gulf Coast. Source: Hanor \& Bailey, 1983, from Bailey, 1878 . 


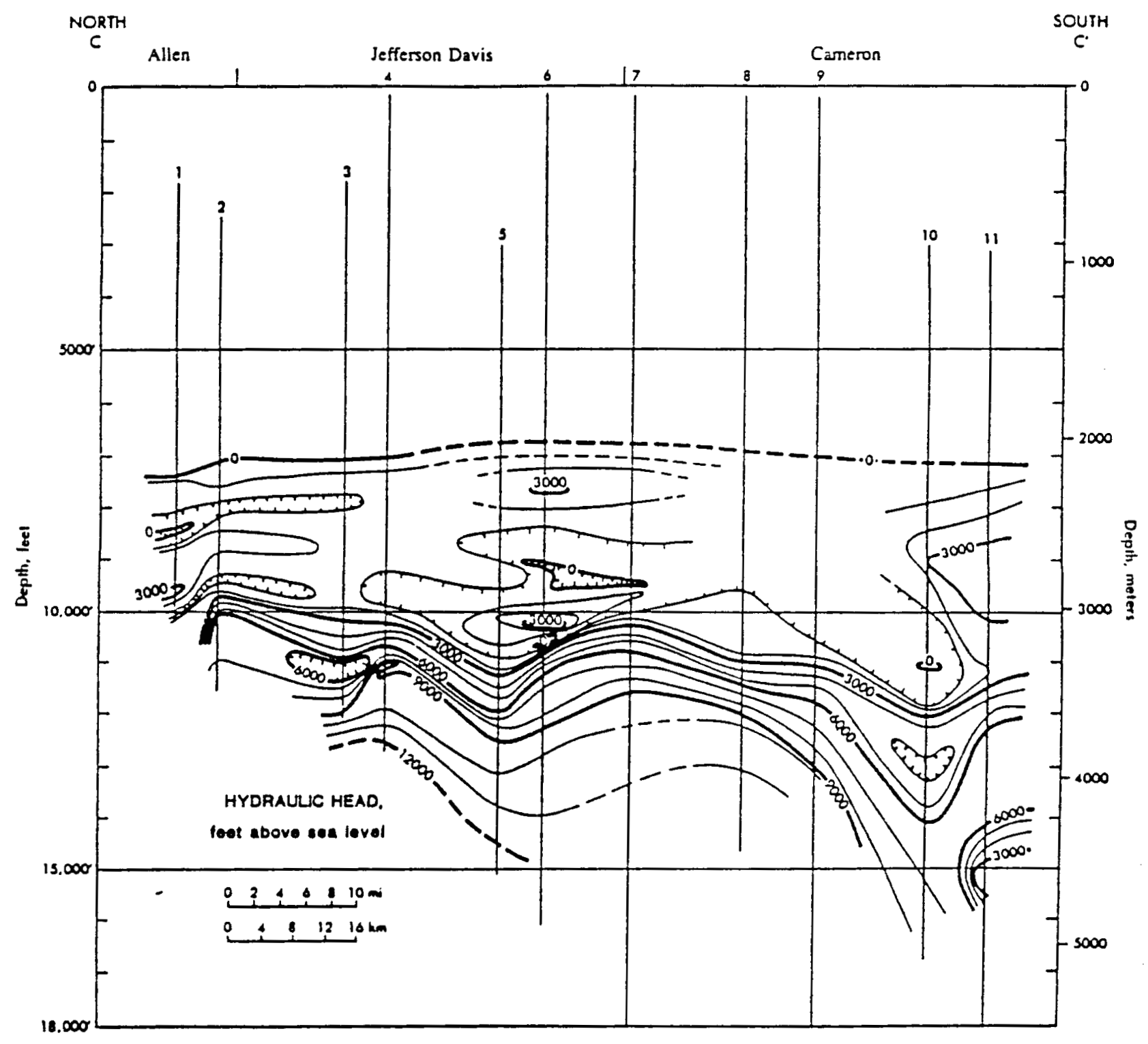

Figure 19. Calculated values of hydraulic head in feet above sea level. All head values are normalized to a pore fluid specific weight of $67.0 \mathrm{lb} / \mathrm{ft}$, which corresponds to a density of approximately $1.07 \mathrm{~g} / \mathrm{cm}$. A head value of 9,000 feet represents a pore fluid pressure sufficient to raise a column of brine 9,000 feet above sea level. Source: After Hanor \& Bailey, 1983 from Bailey, 1978 . 


\section{Collocational Studies from Texas}

In the Texas part of the Gulf Coast Basin existence of the GPGT reservoirs is well established. Many of the GPGT reservoirs underlie producing fields containing heavy and medium oils. For example, sandstones from the upper Wilcox Group (Eocene of South Texas) occurring at depths below $8,000 \mathrm{ft}$ generally have fluid temperatures in excess of $250^{\circ} \mathrm{F}\left(121^{\circ} \mathrm{C}\right)$ and up to greater than $500^{\circ} \mathrm{F}\left(260^{\circ} \mathrm{C}\right)$ and pressure gradients of $0.7 \mathrm{psi} / \mathrm{ft}$. These GPGT fluids underlie the Yegua and Jackson heavy oils of the Mirando Trend. A collocational study of heavy oil and GPGT resources of the Mirando Trend was undertaken for the DOE by Seni and Haml in (1991), Walter, and Kreitler (1990) and forms the basis of the following section.

The Mirando Trend

The Mirando Trend, in the Rio Grande Embayment of south Texas, is approximately 30 miles wide and 100 miles long (Figure 20). The Texas Railroad Commission records indicate there are 87 fields in the trend, producing oil $21.5^{\circ} \mathrm{API}$ gravity or lower. These 87 fields have produced a total of about 320 MMbbls through $1 / 1 / 88$, and in 1987 showed a production of $1.6 \mathrm{MMbbls}$. Of the 87 fields, all but 10 recorded production in 1987 . The depths of the producing reservoirs are 340 to $3,100 \mathrm{ft}$. If $30 \%$ initial recovery is assumed to be represented by $319 \mathrm{Mmbbls}$ of recovered oil, then over 1.0 Bbbls of oil remain in place that could be the target of TEOR. Almost half of this is heavy oil. The oil recoveries from most, if not all, of these fields could be enhanced by a GPGT fluid injection TEOR program (Jackson \& Light, 1987).

Studies by the Texas Bureau of Economic Geology focused on the stratigraphy of the Mirando Trend (Fisher et al., 1970), and the GPGT resources (Gregory et a1., 1980; Bebout, 1982; Morton et al., 1983) in addition to the review of Haml in et a1. (1989). Within the Mirando Trend, the original heavy oil in place (OIP) was $200 \mathrm{MMbbl}$ and has been about $30 \%$ depleted (according to Nehring et al., 1983 and the Railroad Commission of 


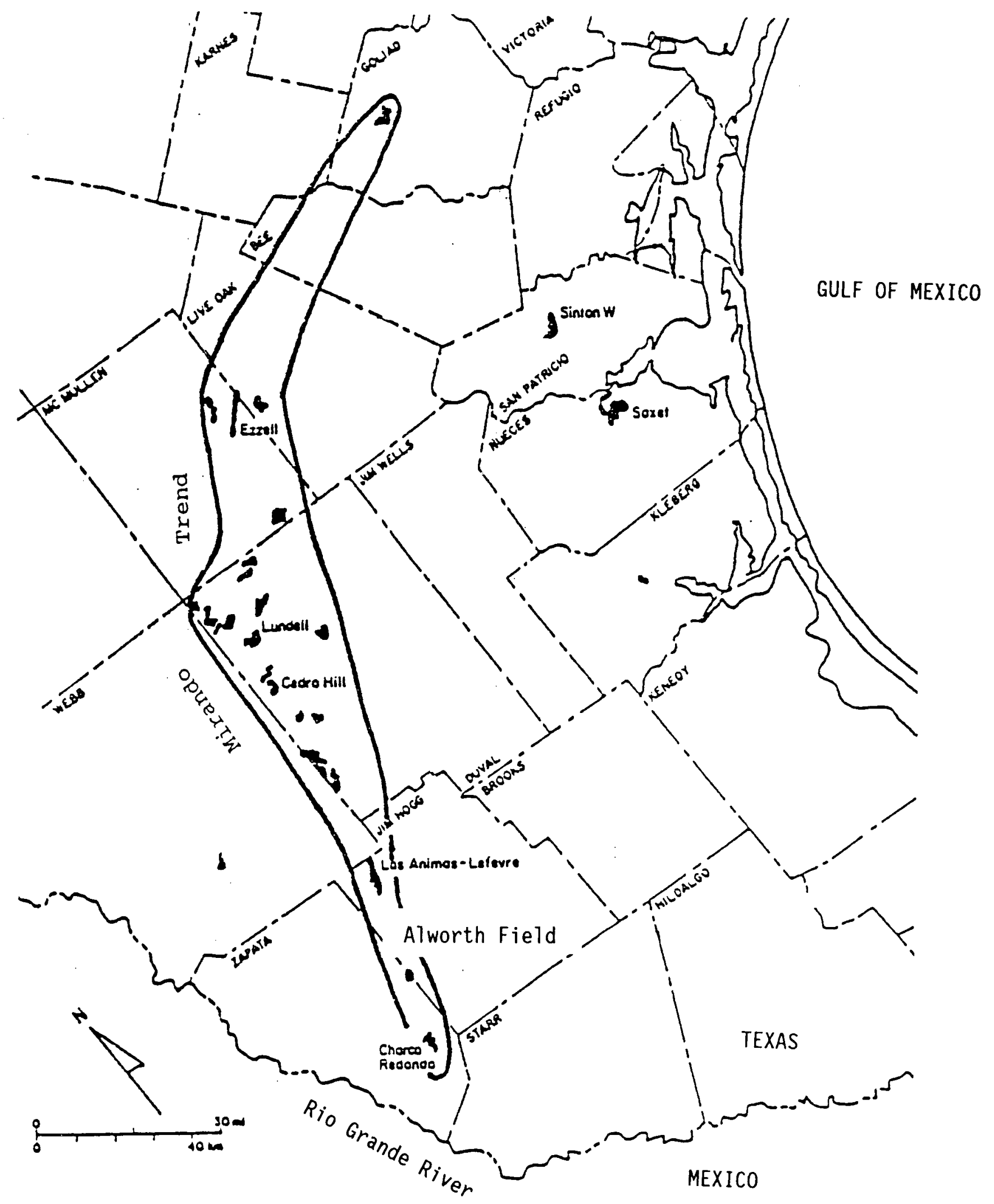

Figure 20. Location map of heavy oils of South Texas showing the mirando trend and the location of the Alworth Field. Source:

Hamlin et al., 1990. 
Texas, 1989). The Trend occurs in Duval, Jim Hogg, McMullen, Starr, Webb, and Zapata Counties. A detrital complex of wave dominated deltaic and barrier island-strand plain sediments of the upper Wilcox Group formed in conjunction with strike oriented growth faults that delimit the reservoirs. These reservoirs form the largest Wilcox gas play in the Gulf coast (Kosters \& Hamlin, 1989). The barrier island-strand plain deposits are thin sandstones separated by lagoonal and marine shelf mudstones facies. The sandstones pinch out updip into the lagoonal facies. and stratigraphic traps are associated with the pinch-out margins and with permeability barriers within the sandstones (Ewing, 1983; Fisher et al., 1970; Schultz, 1982).

The first recorded production of $0 i 1$ in the Mirando Trend was at Charco Redondo Field in Zapata County in 1913, at a depth of $160 \mathrm{ft}$. Starting in the early 1920's, such fields as Carolina-Texas, West Cole, Alworth, Henne-Winch-Farris, Randado, Albercas, Aviators, Bruni, Cole, and Government Wells were discovered. During the depression years, until 1937, very few discoveries were made. However, starting in the late 1930's and accelerating during the Second World War years, many new discoveries of major oil reserves were exploited. New discoveries continue to the made even today but because the Mirando Trend is now a mature exploration area, these later discoveries contain comparatively small reserves.

Production practices up until the 1960's were chaotic and were governed by the "1aw of capture." In most instances the producers ignored engineering conservation practices and blew-down the reservoir energy by flaring the produced gas and dumping produced salt water directly onto the ground. This resulted in primary recovery factors of $<10 \%$ for many reservoirs.

Starting approximately 10 years ago, with the discovery and developments of the deep gas fields in sediments of the Eocene Epoch in Duval, Webb and Zapata counties, it became apparent that a very large deltaic regime existed in these strata in south Texas. The sands are correlatable along trend and occur from about $10,000 \mathrm{ft}$ to $18,000 \mathrm{ft}$ in depth. They are overpressured with pressure gradients of up to $1.0 \mathrm{psi} / \mathrm{ft}$, and bottom hole temperature (BHT) of 250 to $500^{\circ} \mathrm{F}\left(121-260^{\circ} \mathrm{C}\right)$. It is apparent that the Mirando Trend will 
continue to receive large exploratory efforts in the future and, thus, cased and logged dry holes will become available for conversion to GPGT TEOR producers. An estimate of the percentage of wells producing from GPGT reservoirs along the Texas Gulf Coast was made by Jackson and Light (1987) then at University of Texas at Austin, Bureau of Economic Geology (BEG). They concluded from 1983 data that $2 \%$ of the producing wells were producing from geopressured reservoirs (some of those reservoirs are not considered usable for GPGT TEOR). Their database included 50,938 actively producing wells, of which 989 gas wells and 35 oil wells were producing from GPGT reservoirs. By Texas law inactive wells must be plugged and abandoned. Thus to obtain wells for utilization in the GPGT program it would be necessary to negotiate during the late phases of production or immediately prior to plugging and abandoning a wel1. The statistics suggest that at the 1983 drilling level an estimated 2,000 wells might be among candidates for utilization in the Texas and Louisiana Gulf Coast area. With 1989 total drilling effort about 10\% of that in 1983, this estimate is reduced to 200 wells for 1989 alone.

An example of a GPGT reservoir in one of the upper deltaic sands was given in an earlier DOE study (Morton et al., 1983). The First Hinnant Sand, lying $200 \mathrm{ft}$ below the top of the Wilcox Group, is a geopressured reservoir, with 6,627 psi shut in pressure at $9,120 \mathrm{ft}(0.68 \mathrm{psi} / \mathrm{ft}$ gradient $)$ and a temperature of $300^{\circ} \mathrm{F}\left(149^{\circ} \mathrm{C}\right)$. The average porosity is $16 \%$ and the permeability $7 \mathrm{md}$. The measured pore water salinity is $13,000 \mathrm{mg} / \mathrm{L}$. The total available pore water volume for a calculated area of 3.6 square miles of the Hinnant Sandstone is estimated to be between 100 and $800 \mathrm{MMbbl}$. Target reservoir rocks collocated with the Mirando Trend in the Jackson and Yegua formations of the upper Eocene and occur from depths of 160 to 5,000 ft. The trapping mechanisms are stratigraphic and combination traps associated with longshore bars pinching out updip over a terrace or associated fault structure. The produced $0 i 1$ is a sweet paraffin crude of 16 to $45^{\circ} \mathrm{API}$ gravity. The lower gravity oil is termed south Texas heavy and crude producers pay a small bonus for this over other crudes in the area. 0il gravity increases with depth probably as a response to increased thermal maturation. The target reservoir rocks are usually quite porous and permeable and, where effective water drive is present and the viscosity of the oil is 
low, recoveries are excellent. Where an effective water drive is not present, and/or a gas cap or gas-in-solution drive provides the reservoir energy, and the oil has high viscosity, the recoveries are fair to very poor. Some of the larger fields have had pressure maintenance-waterflood programs in existence for years with varying results.

Haml in et al., (1989) generated maps showing the distribution of temperature, pressure, net sandstone, porosity and salinity in relationship to heavy oil fields in the Mirando Trend (Figures 21 through 25). They were able to show the various parts of the upper Wilcox Group that were suitable for extracting GPGT fluids. The collocation of these areas with the distribution of heavy oil provides possible locations for TEOR projects using GPGT fluids (Loucks et a1., 1979; Dodge \& Posey, 1981). 


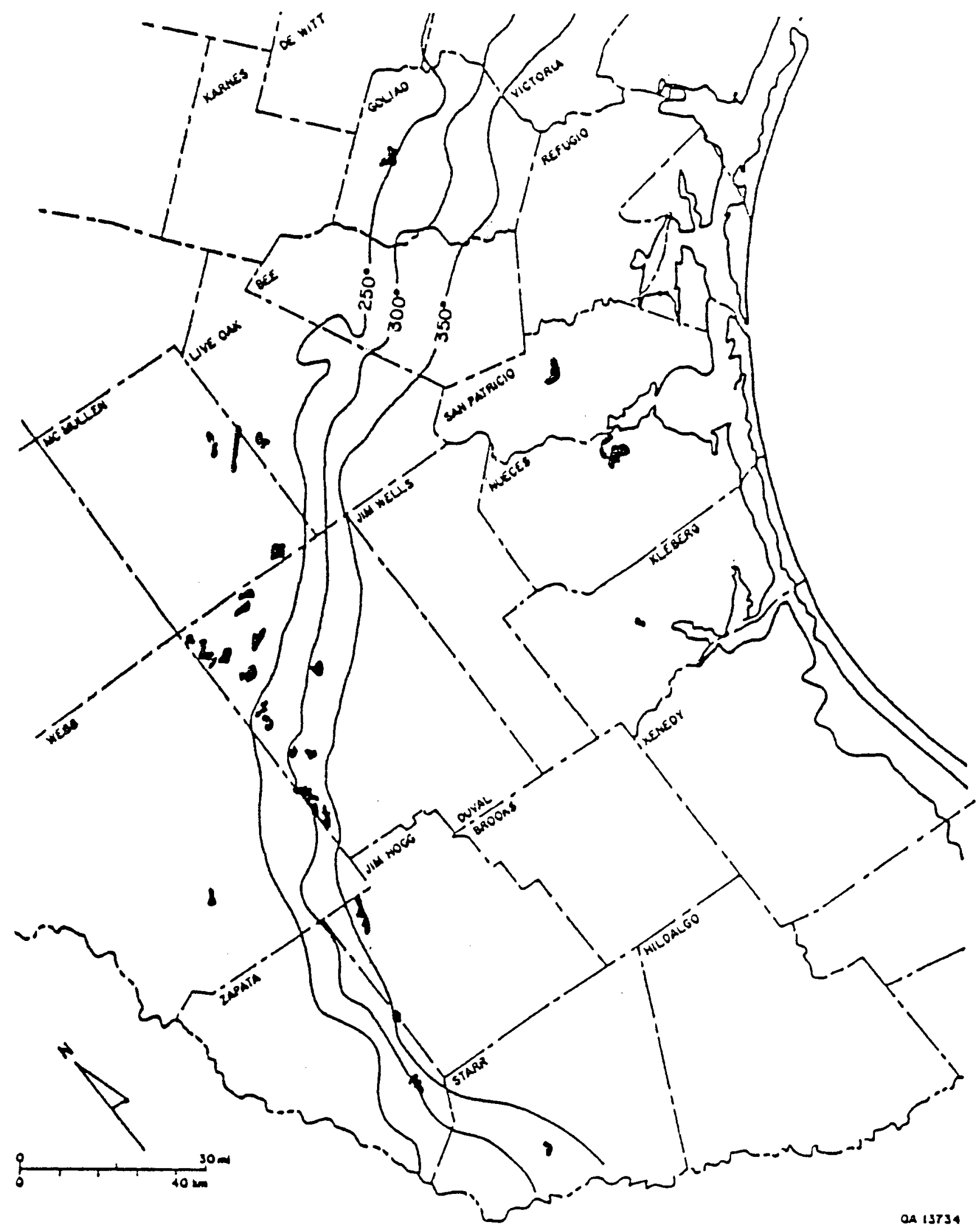

Figure 21. Map showing average fluid-temperature distribution for Deep Upper Wilcox, South Texas. Source: Hamlin et al., 1990. 


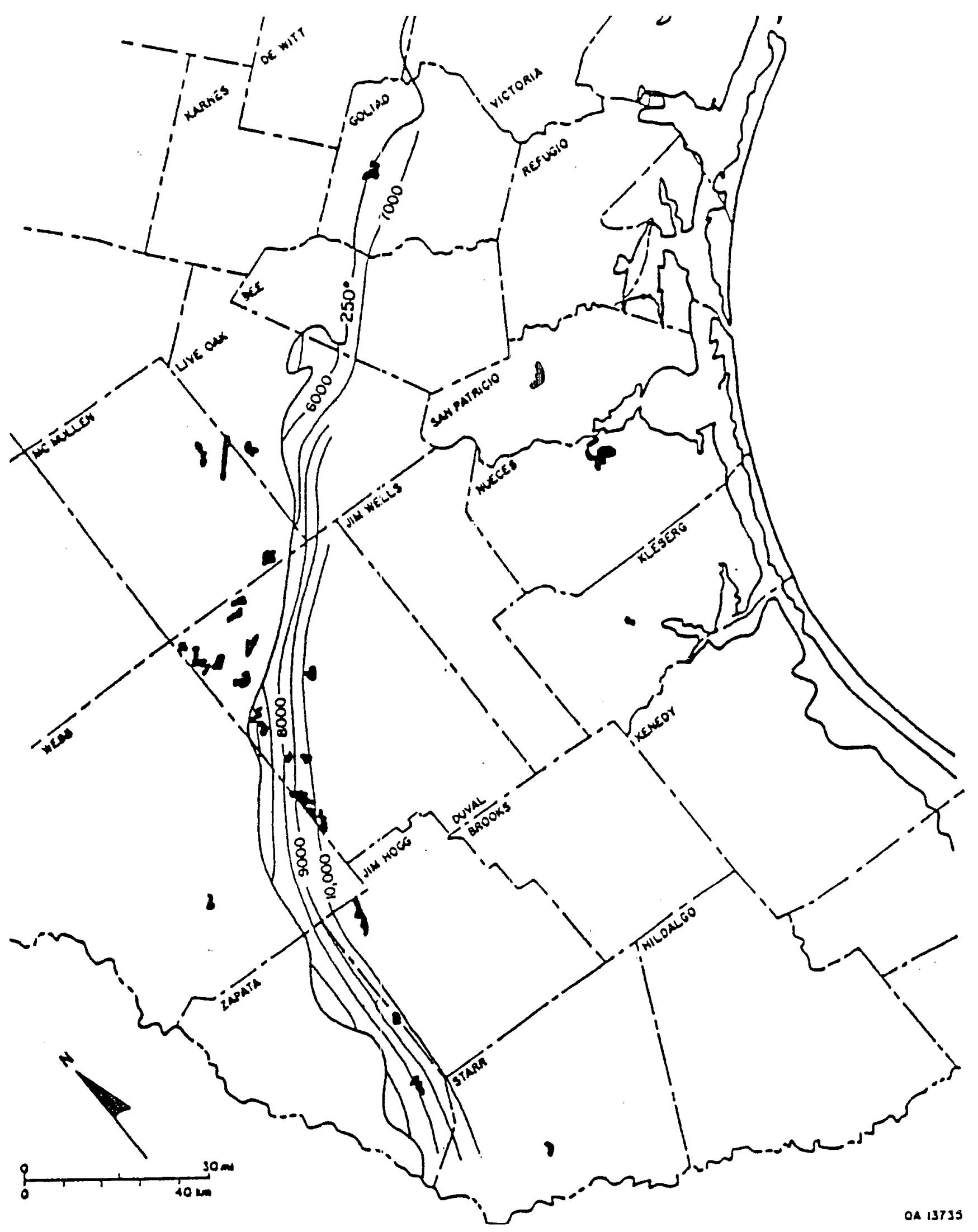

Figure 22. Map showing average fluid-pressure distribution for deep Upper Wilcox, South Texas. Source: Hamlin et al., 1990. 


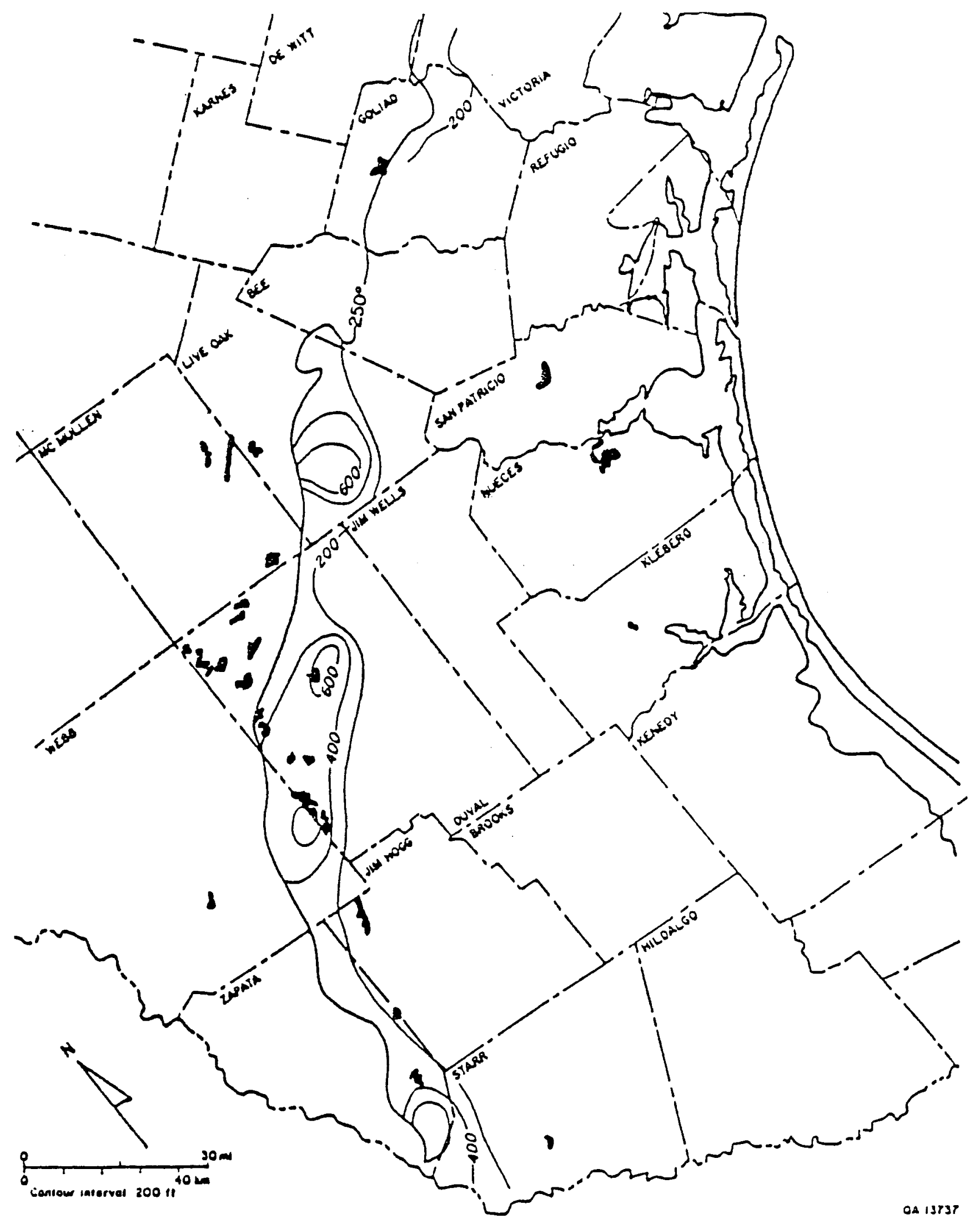

Figure 23. Map showing net sandstone thickness for Deep Upper Wilcox, South Texas. Source: Hamlin et al., 1990. 


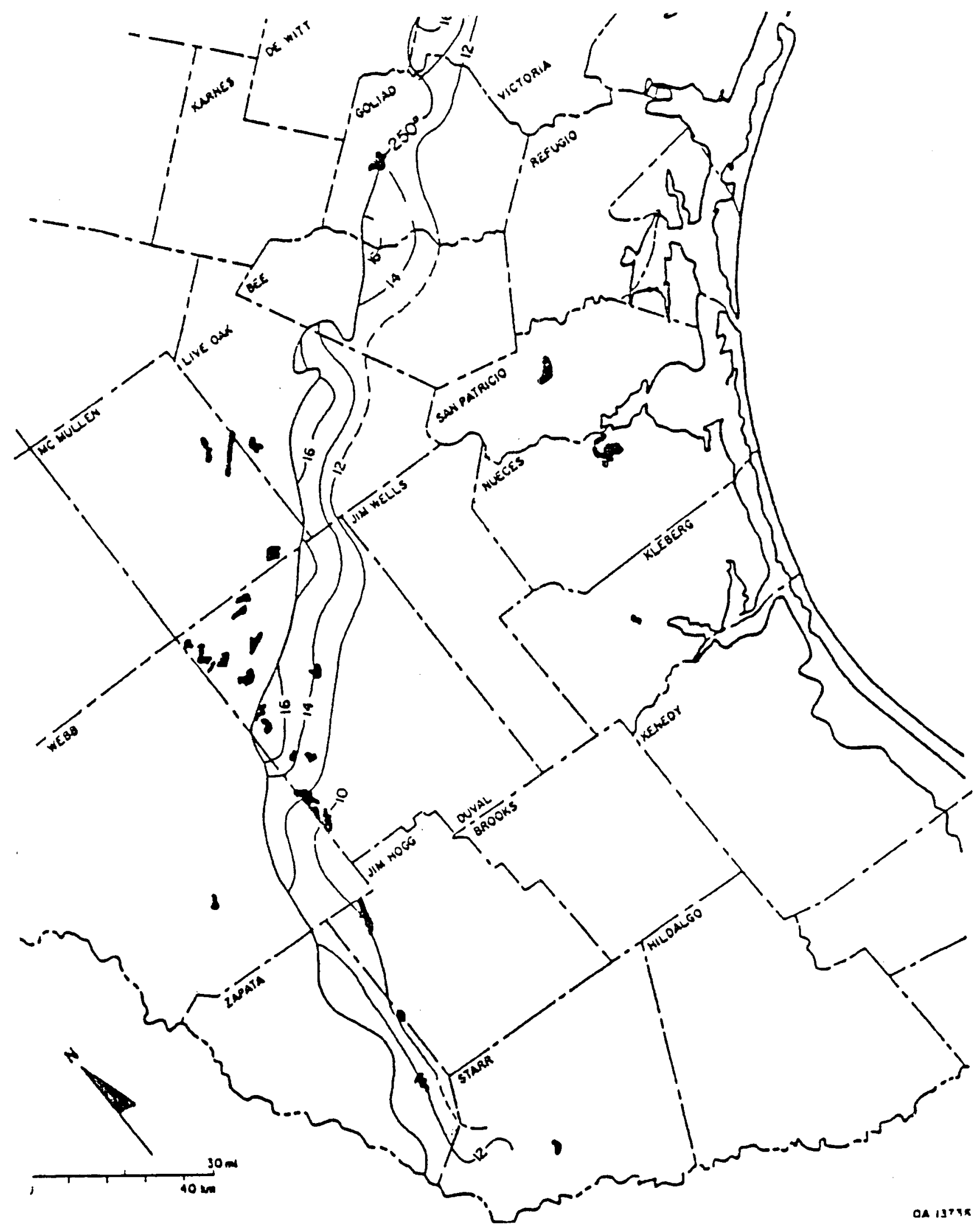

Figure 24. Map showing average porosity for Deep Upper Wilcox, South Texas. Source: Hamlin et al., 1990. 


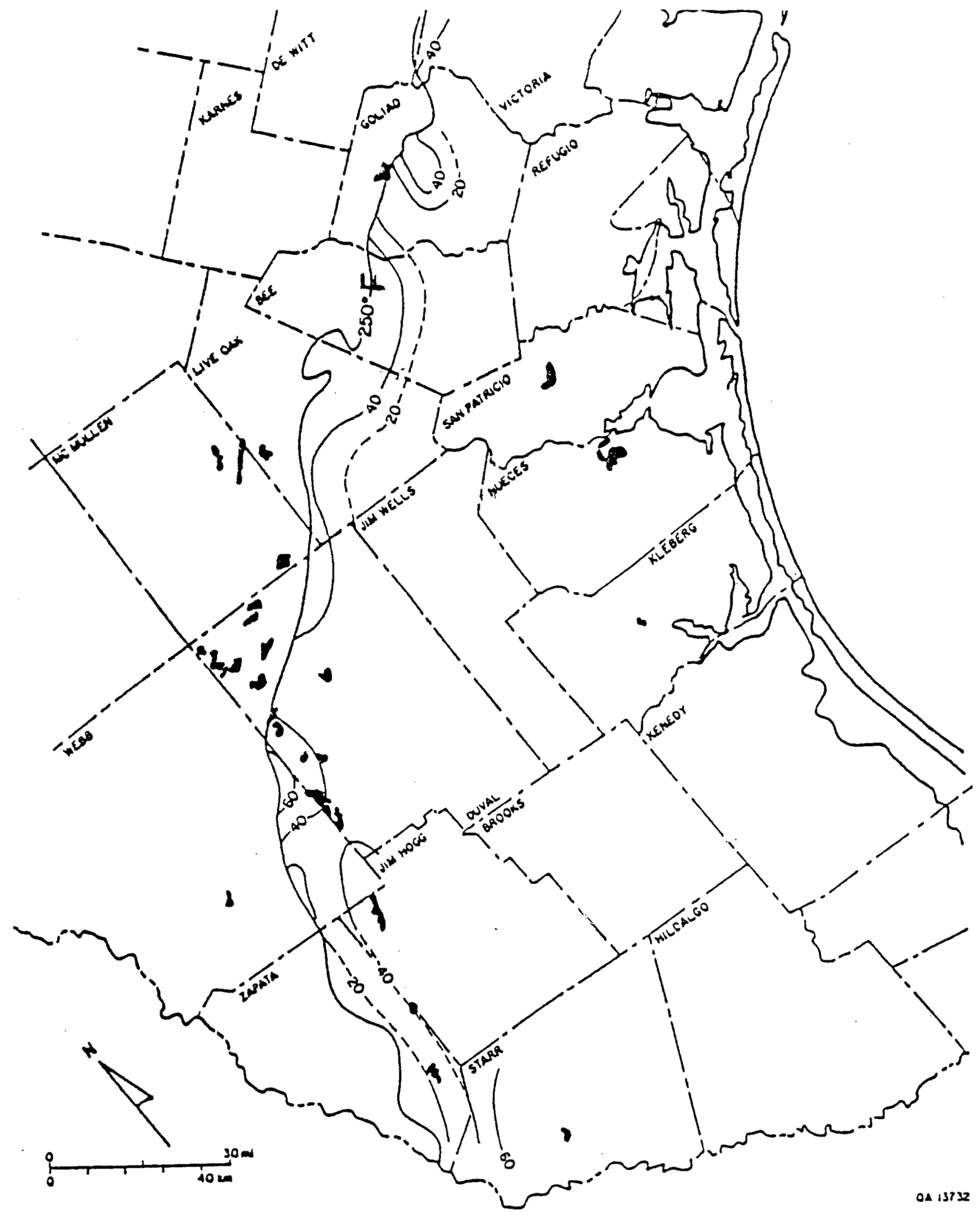

Figure 25. Map showing average pore fluid salinity for Deep Upper Wilcox. Source: Hamilin et al., 1990. Salinity is in ppm. 


\section{Collocational Studies from Louisiana}

The earliest oil (1901) discovered in Louisiana was the Heywood Well 6 miles from Jennings, Acadia Parish. The state is not only of ranked importance in the nation for oil and gas production but also in drilling technology, and a knowledge of the relationship between drilling activities and environmental quality control. The first EOR project was by EXXON Company (1966), who utilized a liquified petroleum gas slug for miscible displacement in a small reservoir on the south flank of the Weeks Island Field (Durham, 1980). Ninety percent (90\%) of the reservoirs in Louisiana have a gravity of $>30^{\circ} \mathrm{API}$. This still leaves a considerable number of producing fields within which GPGT TEOR could be economical. Northern Louisiana contains more than 30 reservoirs that stratigraphically trap oil with a gravity of $\angle 25^{\circ} \mathrm{API}$. Most of these are at depths $<3,000 \mathrm{ft}$. Unfortunately, GPGT reservoirs are not available in northern Louisiana. Collocation studies of heavy oil in Louisiana currently are being undertaken at LSU/LGS. Initial analyses of the data base from the Louisiana Conservative Department indicate a large number of specific sites which test heavy ( 8 to $\left.20^{\circ} \mathrm{API}\right)$ and medium $\left(20\right.$ to $\left.25^{\circ} \mathrm{API}\right)$ oils. The distribution of heavy and medium oils in Louisiana has been studied by Hart et a1., 1991. Initial analyses of the data base from the Louisiana Conservation Department indicate a large number of specific sites which test as bitumens $\left(0-8^{\circ} \mathrm{API}\right)$, heavy ( 8 to $\left.20^{\circ} \mathrm{API}\right)$ and medium $\left(20\right.$ to $\left.25^{\circ} \mathrm{API}\right) 0 i 1 \mathrm{~s}$. These are shown in Figures 26 and 27 . In the southwestern part of Louisiana there are many reservoirs containing oils with a gravity $<25^{\circ} \mathrm{API}$. The target reservoirs are sandstones of the Tertiary Period, and many are water drives. Details of the Louisiana collocational study are contained in Hart et al., 1991.

Because of Louisiana's prominence as a prolific producer of oil and gas, the geological history of the region is well documented. (Bornhauser, 1958; Williamson, 1959; Rainwater, 1967, 1968; Caughey, 1975; Woodbury, et a1. 1973). The thickness of sediments is about 6 miles commencing in the Jurassic with the development of the Mississippi Embayment and the subsequent 


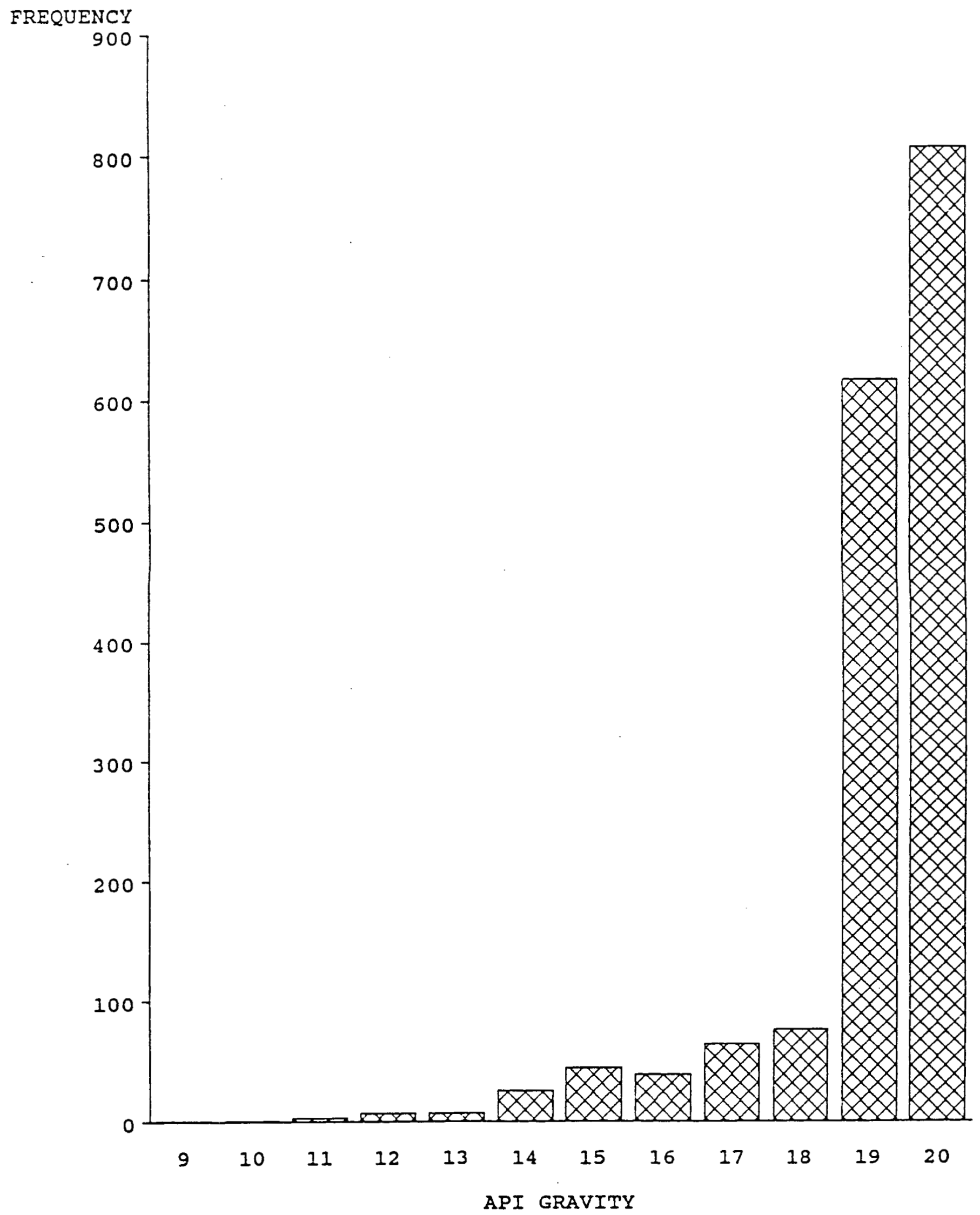

Figure 26. Histogram of the number of heavy oil sites by depth. Source: Hart \& Evans, data file based on Conservation Department, LA. 


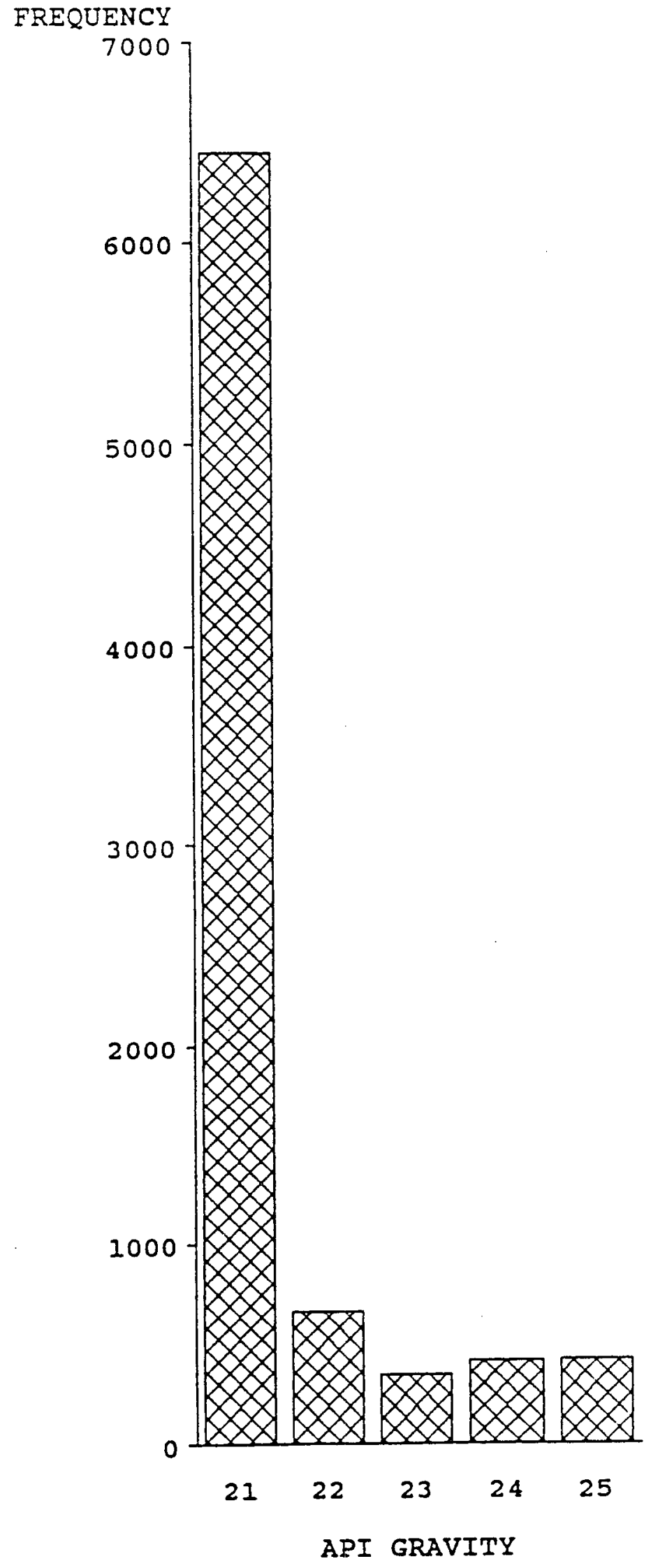

Figure 27. Histogram of the number of medium oil sites by depth. Source: Hart \& Evans, data files based on Conservation Department, LA. 
infilling, especially during the Cenozoic Era, by primarily detrital materials deposited from river systems draining much of the North American continent. Depocenters shifted laterally with time and rapid sedimentation was accompanied by subsidence, growth faulting and accompanying geopressuring (Ocamb, 1961). Data now is accumulating for the substantial role of hydrocarbonbasins with thermal maturation of kerogen (Negus-de Wys, 1991, in preparation). These generation in the development of geopressured compartments in subsiding characteristics can be recognized in shelf margin sediments from as early as the lower Cretaceous Period (Bebout, 1982).

Sediments deposited during the Cenozoic Era that have become geopressured cover a large area (John, Stevenson, \& Graot, 1990). These sediments occur especially below $10,000 \mathrm{ft}$, and have temperatures above $225^{\circ} \mathrm{F}$ $\left(107^{\circ} \mathrm{C}\right)$ (Matthews, 1980). The distribution and depth to the top of geopressured sandstones is given in Figure 28 . In general the top of geopressure is deeper in Louisiana $(9,000$ to $18,000 \mathrm{ft})$ than in Texas $(7,000$ to $12,000 \mathrm{ft}$ ).

"In the geopressured zones, subsurface temperatures of $300^{\circ} \mathrm{F}\left(149^{\circ} \mathrm{C}\right)$ occur at depths of 13,000 to $15,000 \mathrm{ft}$ in west Louisiana and the east Texas Gulf Coast area, and at 15,000 to $18,000 \mathrm{ft}$ in east Louisiana. While porosity generally decreases uniformly with depth (Loucks et al., 1979), it is not uncommon to see wide local variations in porosity and permeability at any particular depth because of variations in original sand composition, fluid movement and chemistry, geopressure, temperature, and effects of digenes is (John, 1988). Highly variable salinities ranging from $100,000 \mathrm{ppm}$ to under 20,000 ppm have been found in the geopressured zones in different areas (Bebout \& Gutierrez, 1981)." (John, Stevenson, \& Groat, 1990).

In the Upper Wilcox Formation of south Texas geopressured temperatures can be in excess of $500^{\circ} \mathrm{F}\left(260^{\circ} \mathrm{C}\right)$.

The Louisiana GPGT research has addressed the environmental effect of producing large quantities of brine. The major concerns are the possibility of subsidence, fault activation, and contamination of freshwater aquifers. 


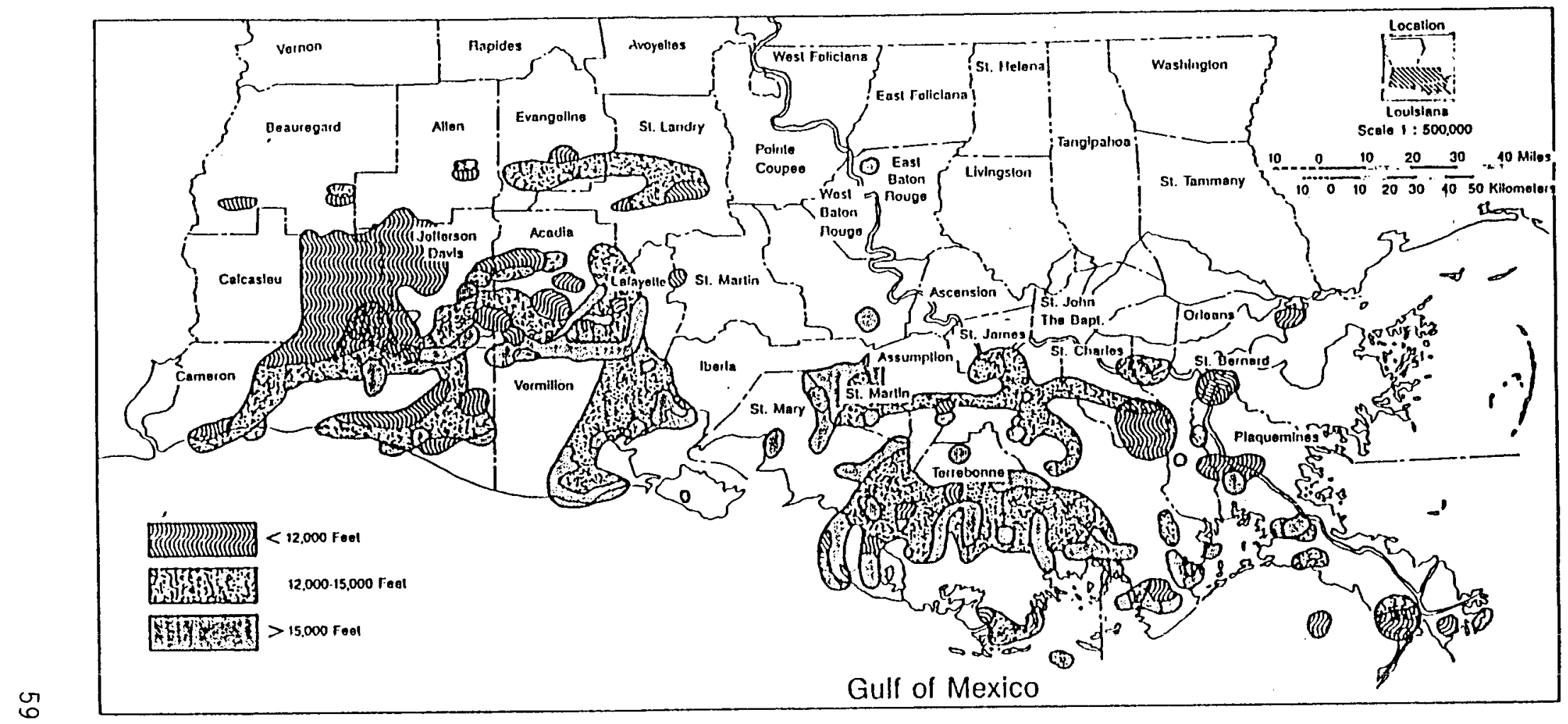

Figure 28. Distribution and depth to the top of geopressured sands, Louisiana. Source: McCulloh et al., 1986. 
Currently, the brines are disposed of by subsurface reinjection through shallow disposal wells into isolated saltwater aquifers about $6000 \mathrm{ft}$ deep. The LSU/LGS environmental program monitors land subsidence and fault activity with up to five continuously operated microseismic recording stations at each site. Periodically-surveyed first-order benchmark networks tie the systems into the National Geodetic Survey regional network. The water quality was monitored by samples analyzed from surface stations and groundwater aquifers for possible contaminants originating from GPGT brines.

"The environmental monitoring (continuous microseismic, subsidence, and water quality) of test sites before, during, and after well testing has shown no significant detrimental environmental effects from the long term production and subsurface disposal of gas-separated brines into saline aquifers" John, Stevenson, and Groat, 1990.

\section{Future Application}

The San Joaquin Basin, California

A project similar to the one proposed for south Texas and Louisiana may be possible around the southern margins of the San Joaquin Basin (Kern County), at the southern end of the Great Valley, California (Figure 29), where important heavy oil reservoirs are located. Haml in et al. (1990) and Negus-De Wys, (1989) reviewed the potential of the San Joaquin Basin for collocation of heavy oil reservoirs and availability of GPGT fluids suitable for a TEOR project. Comparison of world heavy oil production with recoverable heavy oil in Kern County, California (2.5 Bbbls of 12 to $23^{\circ} \mathrm{API}$ gravity oil) is shown in Figure 30. The major problem is the lack of conclusive data relating to the collocation of GPGT source reservoirs and the shallow, heavy oil, target reservoirs. 


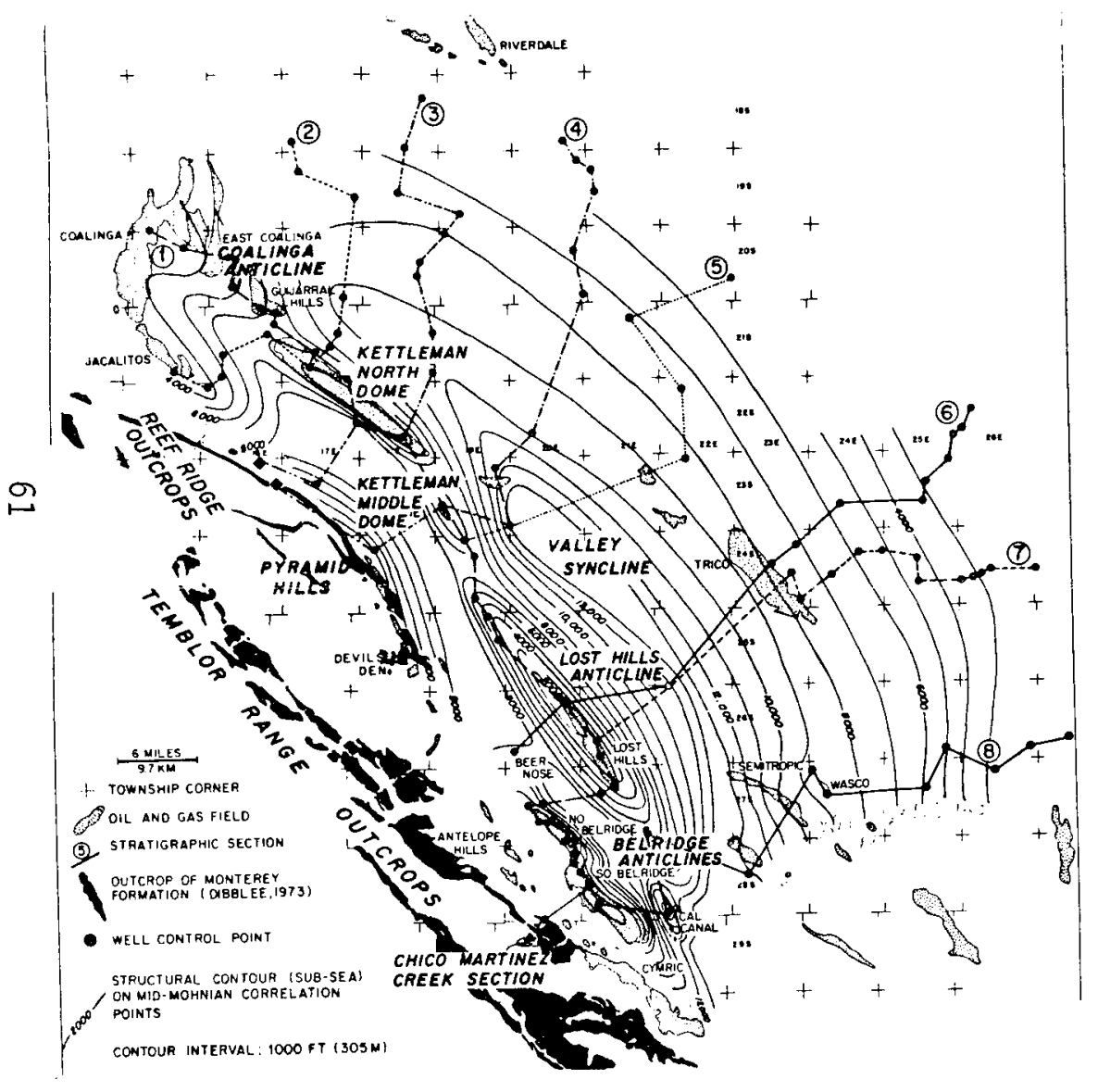

Figure 29 Subsurface map of the central part of the San Joaquin Basin showing principal locations. Source: Graham \& Williams, 1984.

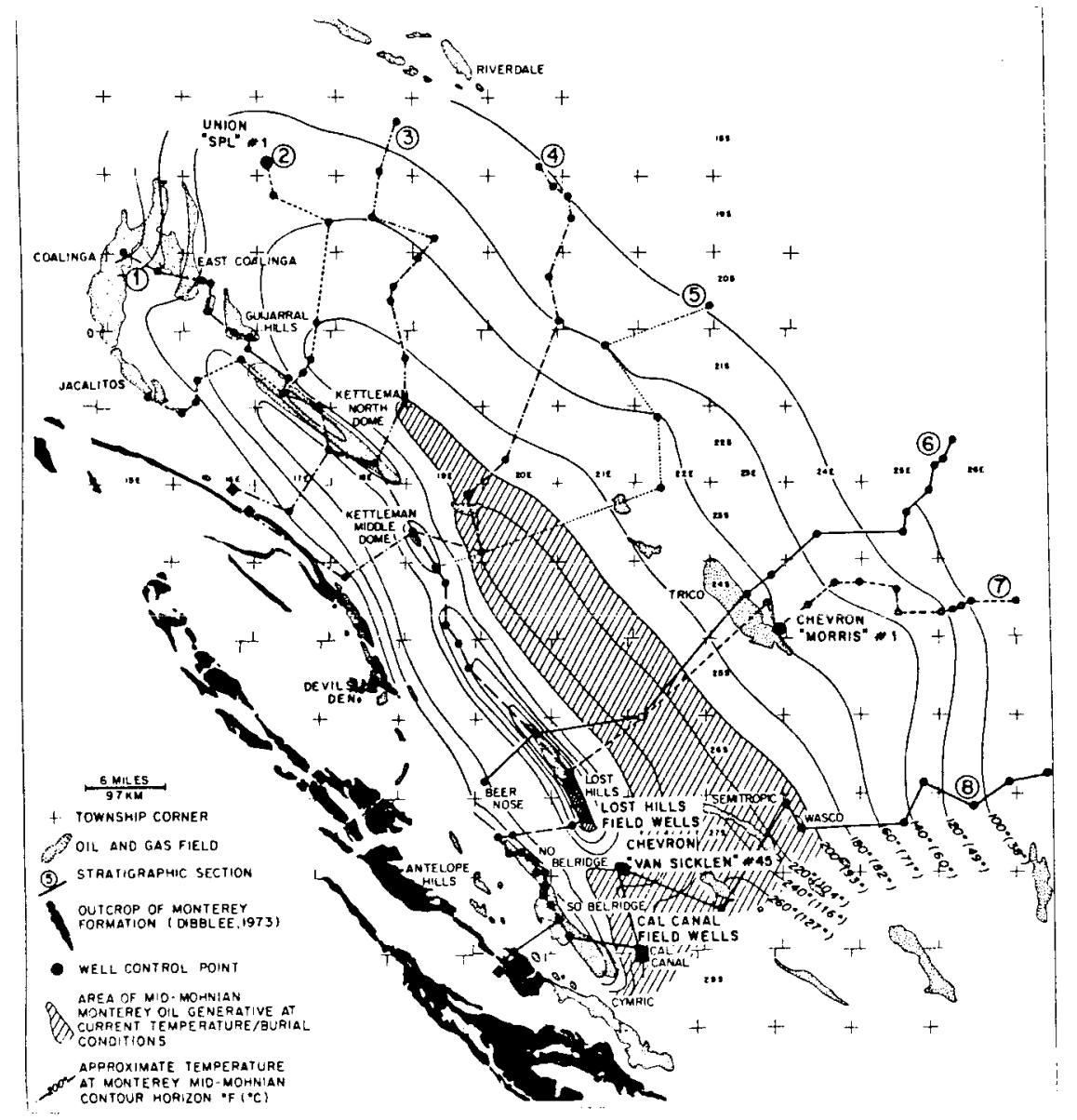

Figure 31. Geothermal gradient for the central part of the San Joaquin Basin. Source: Graham \& Williams, 1984. 


\section{HEAVY OIL PRODUCTION (MMBBLS)}

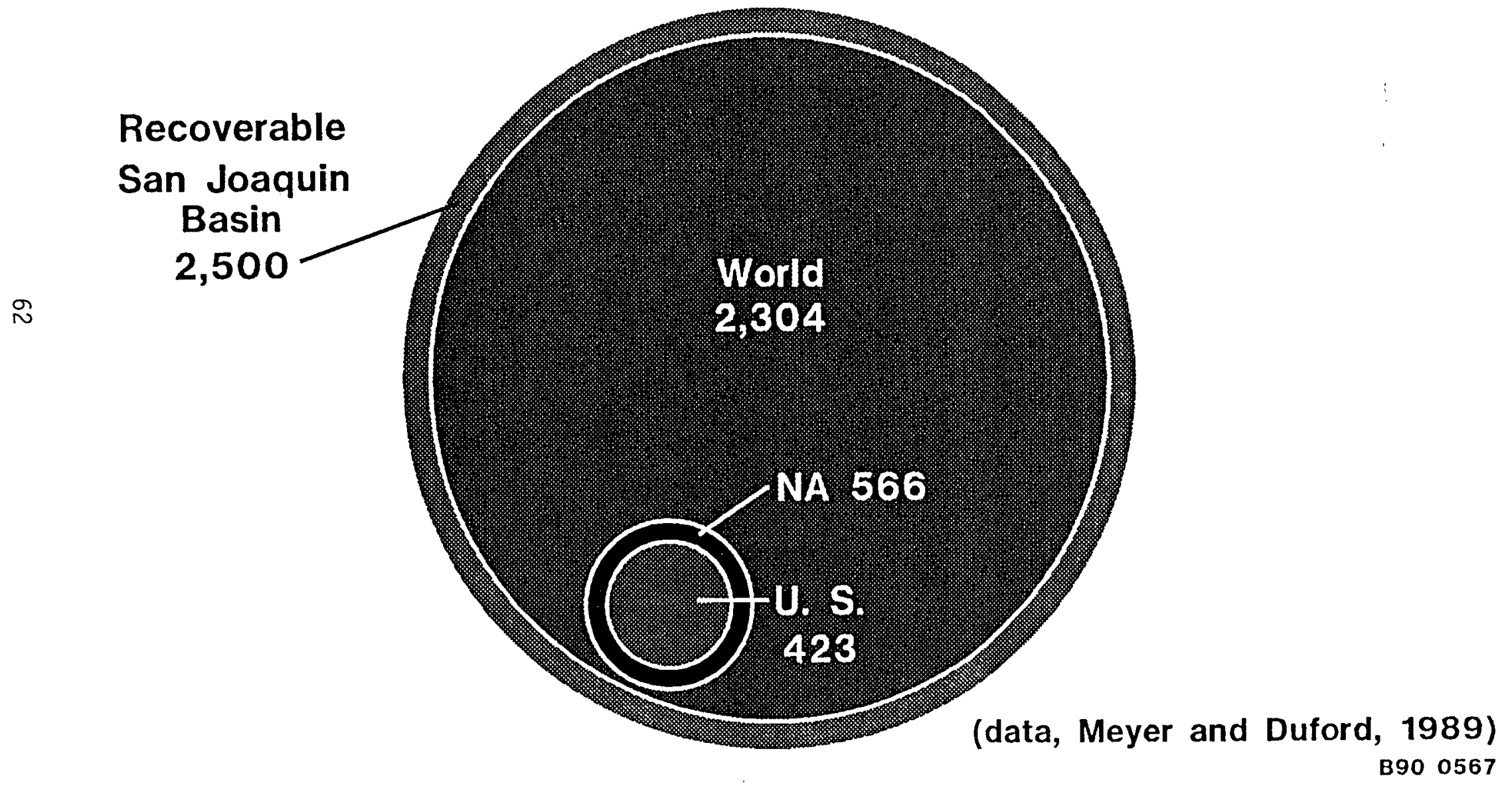

Figure 30. Heavy oil production compared with San Joaquin Basin Kern oil County recoverable heavy oil. Source: Graham \& Williams, 1984. 
The San Joaquin Basin as a whole contains billions of barrels of heavy oil reserves but the GPGT reservoirs have not been clearly delimited by drilling. The most favorable parts of the basin for GPGT fluids are in the southern and western parts of the basin. Typical heavy oil fields in the area containing prospective target reservoirs include the Coalinga Field, in Fresno County and Lost Hills, Cymric, McKittrick, and Midway-Sunset fields in Kern County (Berry, personal communication 1989). Kern County alone is reported to have 59 large reservoirs containing approximately $18 \mathrm{bbl}$ of heavy oil (Haml in et al., 1990). Isolated well data and regional geological appraisal of the basin suggests high fluid pressures and elevated temperatures $\left(>250^{\circ} \mathrm{F} ;>121^{\circ} \mathrm{C}\right.$ ) commonly occur below $9,000 \mathrm{ft}$ in these areas.

The San Joaquin Basin has a complex history and has taken many different basinal forms. It was originally part of the Great Valley Fore-arc during the Mesozoic Era, and it became structurally segmented at the beginning of the Cenozoic Era. The dominant early basin fill was a series of progradational submarine fans. As the San Andreas fault system began to isolate the basin from the Pacific Ocean during the mid-Tertiary Period (Pliocene Epoch) the marine sequence was replaced by Bajada and eventually intermontane sedimentation (alluvial and playa lakes sequences). The distribution of GPGT in the San Joaquin Basin probably is related more to structural deformation than sedimentation (Hamlin et al., 1990) the highest pressures occurring along fold axis (Berry, 1973). "The San Andreas Fault to the west and a fault at depth bounding the western edge of the Sierra Nevada batholith on the east side of the basin have caught the Cretaceous Great Valley clastic sequence in a vise-like grip, compressing the sediments and increasing formation pressures (Berry, 1973). "The Temblor mountain building episode was one consequence of the process" (Haml in et al., 1990). The overlying structural and stratigraphic traps also are often axial and lie above the potential GPGT zones (Callaway, 1968; Foss \& Blaisde11, 1968; Berry, 1973). The general geothermal gradient is calculated as $0.55^{\circ} \mathrm{F} / 100 \mathrm{ft}$ between $3,000-6,000 \mathrm{ft}$ and $1.1^{\circ} \mathrm{F} / 100 \mathrm{ft}$ below $12,000 \mathrm{ft}$ (Graham \& Williams, 1984). Wallace (1979) suggests a slightly higher geothermal gradient of $1.8^{\circ} \mathrm{F} / 100 \mathrm{ft}$; and, Strongin (1981) between 2.0 to $3.5^{\circ} \mathrm{F} / 100 \mathrm{ft}$. The thermal gradient up to the Miocene Epoch was much higher than present, due to proximity to a triple junction and 
subducting plate boundary. The change essentially is related to the propagation of the San Andreas Fault passing the basin. The pressure generally increases rapidly with depth because of the effects of the wrench tectonism caused by the fault.

Because of the maturity level of the sediment fill, the high Total Organic Carbon values ( 0.49 to $9.16 \mathrm{wt}$. \%), and the dominance of amorphous protistoclastic material, hydrocarbons are widely distributed in the San Joaquin Basin. Many Californian giant oil fields are found in the area because of the abundance of the marine turbidite fan deposits, numerous transgressions and regressions, and overall structural development of the basin. The most common types of hydrocarbons found are resinous and heavy crudes. Most of the production comes from the detritals of the upper Miocene Epoch, which are either deep water turbidites or their up-dip equivalents (Macpherson, 1978). Most heavy oil resources occur in shallow reservoirs in the lower Pliocene Etchegoin Formation and the overlying Tulare Formation, in the western half of the basin. Several good heavy oil reservoirs do occur deeper in the Carneros Sand of the Temblor Formation (1ower Miocene Epoch) and the Tumey Formation (0ligocene Epoch). Tertiary GPGT fluids may be found as shallow as $400 \mathrm{ft}$ (Wallace et al., 1979) and in the Lost Hills field at 1,000 ft within the Etchegoin Formation (Berry, 1973; Thomas, 1979; Williams, 1988).

Relevant temperature and pressure data for the western part of the San Joaquin Basin are scarce. A generalized geothermal gradient map for the central part of the San Joaquin region is given in Figure 31 . The results of the work of Berry (1973) on fluid pressures that were hydrostatic, intermediate, and near lithostatic are summarized in Figure 32 . The detritals of the Cretaceous Period have the highest pore pressures. Haml in et al., (1990) provided temperature ranges for some heavy oil fields. As would be expected in a tectonically active region pore water salinites are not related to depth $(10,000$ to $30,000 \mathrm{mg} / \mathrm{L}$ TDS in Tertiary sediments between 500 to $10,000 \mathrm{ft})$. Hamlin et a1., (1990) suggested that horizons deeper than $10,000 \mathrm{ft}$ probably have less than $30,000 \mathrm{mg} / \mathrm{L}$ TDS. 


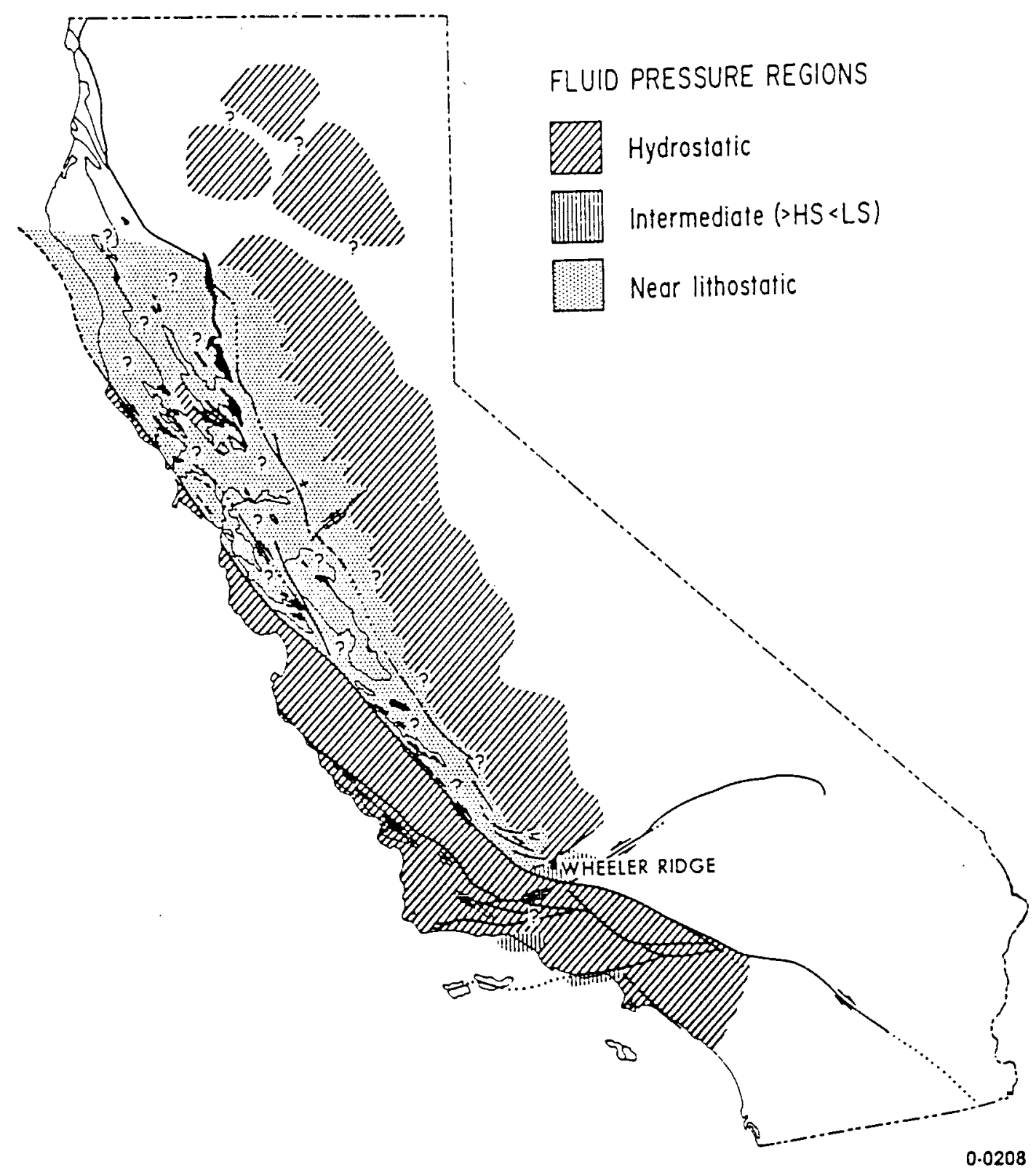

Figure 32. Fluid pressure regions in California. Source: Berry, 1973. 
In addition to the San Joaquin Basin resources Haml in et al., (1990) reviewed the heavy oil fields of the Los Angeles Basin. They note that most of the heavy oil accumulations are associated with major fault zones and suggest the Inglewood, Huntington Beach, and Whittier fields are typical.

"Heavy-oil-producing zones in the Los Angeles Basin vary stratigraphically from field to field. Inglewood field, through 1963, produced more than $174.5 \mathrm{MMbbl}$ of $19^{\circ} \mathrm{API}$ gravity oil from the uppermost horizons: Upper Investment and Investment members of the Pico Formation (Pliocene), and the Vickers - Machado member of the Pico - Repetto Formation (Dietzman and others, 1966). Heavy-oil production farther inland at Whittier Field comes mainly from the Repetto Formation, with some contribution from the Puente Formation."

"Secondary stimulation techniques have been employed in most fields in the Los Angeles Basin. The most common methods have been water flooding and cyclic steam injection of the heavy-oil reservoirs" (Haml in et al., 1990).

The California Energy Commission has initiated a study of GPGT resources in the State of California (Mike Smith, 1989, personal communications). The results of this study will assist in assessing the potential for using the GPGT fluids for TEOR. Because the San Joaquin Basin presently provides most heavy oil production in the United States it would become a major area of GPGT TEOR activities if the technology is proven. 


\section{PILOT STUDIES}

The collocation studies currently taking $\mathrm{place}$ in south Texas and southern Louisiana are mapping the shallow locations of medium and heavy oil that coincide with deeper locations of GPGT brine reservoirs. This section describes the site for an initial pilot study in Texas.

An understanding of the geology of the area, production technology, surface handling and injection of geopressured fluids, brine-reservoir interactions, and production of heavy oils using GPGT fluids for water flooding are all important aspects to be considered prior to a TEOR project.

\section{Alworth Field: South Texas}

The importance of the GPGT fluid in the area of south Texas is enhanced because it is not possible to consider TEOR methods using steam or hot water because of the lack of suitable quality fresh water. As in much of Texas, the region is semi-arid and the limited ground water supply is strongly controlled by the surface owners who are predominantly ranchers. Moreover, the local and state authorities control the limited fresh water in favor of surface users.

Location

The Alworth Field occurs in Jim Hogg County, Texas and geologically overlies the Mirando Trend. It occupies a small structural high about 1.5 miles by 0.5 miles in extent.

\section{Source Reservoir}

The characteristics of GPGT reservoirs in the general area of the site can be based on the local data from the Mirando Trend. The thermal brine will be drawn from a GPGT well situated well within the upper Wilcox Group (13,000 to $16,000 \mathrm{ft}$ ). These reservoirs have porosities of 9 to $17 \%$, formation fluid temperatures of $>250^{\circ} \mathrm{F}\left(>121^{\circ} \mathrm{C}\right)$, fluid pressure gradients of $0.7 \mathrm{psi} / \mathrm{ft}$, and 
pore fluid salinities ranging from $<20,000$ to $70,000 \mathrm{mg} / \mathrm{L} \mathrm{NaCl}$. At greater depths higher temperatures occur, ranging from 350 to $500^{\circ} \mathrm{F}\left(177\right.$ to $260^{\circ} \mathrm{C}$ ) (Kimme11, private communication, 1989). Porosities of 26 to $30 \%$ are recorded in the Wilcox Group between 16,000 to $18,000 \mathrm{ft}$. Gas content in the brine is reported to be high; $62 \mathrm{scf} / \mathrm{bbl}$ and $100 \mathrm{scf} / \mathrm{bbl}$ are estimated based on temperature, pressure, and total dissolved solids of $3,600 \mathrm{mg} / \mathrm{L}$ (INEL analysis, 1989: Table 8; Negus-de Wys, 1989). There is no direct information on the brine productivity of these zones at the Alworth Field. However, it is expected that, like Hul in site, the production will be well-bore limited. Production rates of 20,000 bpd are reasonable with only 10,000 bpd required for the recovery project. Little excess pressure at the surface is expected because of the depth of the resource and well-bore losses; therefore, utilization of hydraulic energy may not be realistic for this site. Nevertheless, the Wilcox Group may contain some of the more promising GPGT reservoirs with their higher temperatures, pressures, low total dissolved solids, and potentially high gas content.

The field separator receives the gas from 11 gas wells, which deliver about $5 \mathrm{bcf} /$ month. The gas is mainly methane with approximately $14 \% \mathrm{CO}_{2}$. This raises the definite possibility that the low TDS measurements are wrong. In gas wells fresh water often condenses as the fluid reaches the surface. This mixes with the true reservoir water and reduces the overall TDS of any sample analyzed. This point is particularly relevant because of the large number of gas wells (11) and the fact that relatively small amounts of produced water occur. The contrary argument that the analyses are real rests on the local knowledge that low salinity waters have been observed at depth (Kimme11, private communication, January, 1991). At depth high temperatures occur, ranging from 350 to $500^{\circ} \mathrm{F}\left(177-260^{\circ} \mathrm{C}\right.$ ) (Kimme11, private communication, 1989). Porosities of 26 to $30 \%$ are recorded in the Wilcox Group between 16,000 to $18,000 \mathrm{ft}$. There is no direct information on the brine productivity of these zones at the Alworth Field site. However, it is expected that, like the Hul in site, the production will be well-bore limited. Production rates of 20,000 bpd are reasonable with only 10,000 bpd required for the recovery project. Flowing well head pressure has been about 3,400 psia, enough to consider a modest hydraulic conversion project. The Wilcox 
Group may contain some of the more promising GPGT reservoirs with their higher temperatures, pressures, possibly low total dissolved solids, and potentially high gas content.

One of three nearby GPGT wells can be re-entered and re-completed to supply about $350^{\circ} \mathrm{F}\left(177^{\circ} \mathrm{C}\right)$ brine from 15,000 to $16,000 \mathrm{ft}$. These wells are within 2.5 miles of the Alworth Field. One of these will be re-entered, recompleted and piped overground to the field for about half of the cost of drilling a new well. This well could produce 15,000 to $20,000 \mathrm{bbl} /$ day of brine having a temperature of $350^{\circ} \mathrm{F}\left(177^{\circ} \mathrm{C}\right)$ or greater. A preliminary review shows that it is possible to attain the desired temperature $\left(200^{\circ} \mathrm{F} ; 93^{\circ} \mathrm{C}\right)$ in this reservoir system within 6 months, and complete a GPGT TEOR project within 3 years.

The important question regarding the GPGT fluids is 'Could the brine be delivered to the field without significant heat losses?' The actual temperature of the brines is unknown but economic analysis assumed two different scenarios: 350 and $500^{\circ} \mathrm{F}\left(177\right.$ and $\left.260^{\circ} \mathrm{C}\right)$. The upper 1 imit is based on data from the Fandango Field to the north. Assuming a production rate of $12,000 \mathrm{bbl} /$ day $(350 \mathrm{gal} / \mathrm{min})$; a 6 inch insulated pipeline carrying the brine $13,200 \mathrm{ft}$ to the $011 \mathrm{field} ; 1$ inch of pipe insulation (thermal conductivity of $\left.0.22 \mathrm{BTU} / \mathrm{hr} / \mathrm{ft} /{ }^{\circ} \mathrm{F}\right)$; and an ambient temperature of $70^{\circ} \mathrm{F}\left(21^{\circ} \mathrm{C}\right)$ a one dimensional radial conduction analysis was run for the project. The results indicate 338 to $482^{\circ} \mathrm{F}\left(170\right.$ to $\left.250^{\circ} \mathrm{C}\right)$ brine can be delivered to the Alworth Field for the initial temperature assumption range of 350 to $500^{\circ} \mathrm{F}(177$ to $260^{\circ} \mathrm{C}$ ). Heat losses can be reduced by increased insulation or by burial of the pipeline.

\section{Target Reservoir}

The proposed target reservoir is the shallow Cole Sandstone presently producing $18.6^{\circ} \mathrm{API}$ gravity crude from five wells. It is located at a depth of about 1,000 ft within the gentle north to south closure that forms the Alworth Field. The sandstone thickness is zero at the northern side of the structure, where it shales out, to about $30 \mathrm{ft}$ in the thickest section, There is a net $0 i 1$ thickness of $15 \mathrm{ft}$ at the crest of the structure. The average net $0 i 1$ 
sand thickness is $7.5 \mathrm{ft}$, with an area of about 320 acres. The average porosity is $30 \%$ and permeability 1,500 (range of $40-3,000$ ) millidarcy. A structure map on the top of the Cole Sandstone and an isopach map of the reservoir is shown in Figures $33 \& 34$. The total $0 i 1$ in place is estimated to be more than 4 MMbbl, of which a minimum of 1 MMbbl is believed to be mobile oil, recoverable by GPGT TEOR technology. The characteristics of this target reservoir and the thermal properties of the field are provided in Tables 9 \& 10 (Kimme11, personal communication, 1989). Over 3 MMbbl are estimated to be in place and it is anticipated that about 1 MMbbl additional barrels will be recovered using GPGT TEOR. To date only about $2.7 \%$ of the original heavy oil in-place (OHOIP) has been produced.

One important question to answer with regard to the target reservoir is 'Could the reservoir be sufficiently heated at a total field injection rate of $12,000 \mathrm{bbl} /$ day?' The method of Lauwerier (1955) was used to estimate the reservoir temperature distribution with time for hot water injection. The thermal assumptions used are given in Table 9.

Table 9. Reservoir thermal properties, Alworth Field, South Texas

\begin{tabular}{||ll||}
\hline Thermal Conductivity of Overburden & $=34 \mathrm{BTU} / \mathrm{ft}$-day ${ }^{\circ} \mathrm{F}$ \\
Thermal Conductivity of Reservoir Rock & $=34 \mathrm{BTU} / \mathrm{ft}$-day ${ }^{\circ} \mathrm{F}$ \\
Density of Overburden (Silty Sand) & $=132 \mathrm{lb} / \mathrm{ft}^{3}$ \\
Heat Capacity of Overburden (Silty Sand) & $=.288 \mathrm{BTU} / 1 \mathrm{~b}-{ }^{\circ} \mathrm{F}$ \\
Density of Reservoir Rock (Sand Stone) & $=142 \mathrm{Ib} / \mathrm{ft}^{3}$ \\
Heat Capacity of Reservoir Rock (Sand Stone) & $=.252 \mathrm{BTU} / 1 \mathrm{~b}-{ }^{\circ} \mathrm{F}$ \\
Heat Capacity of Water & $=1.0 \mathrm{BTU} / 1 \mathrm{~b}-{ }^{\circ} \mathrm{F}$ \\
Heat Capacity of $0 i 1$ & $=.4 \mathrm{BTU} / 1 \mathrm{~b}-{ }^{\circ} \mathrm{F}$ \\
\hline
\end{tabular}


Table 10. Summary reservoir data sheet, Alworth Field, South Texas.

\begin{tabular}{|c|c|c|}
\hline Area & $=$ & 320 acres \\
\hline Average Pay Thickness & $=$ & $7.5 \mathrm{ft}$. \\
\hline Average Porosity & $=$ & $30 \%$ \\
\hline Water Saturation (initial) (SWi) & $=$ & $46 \%$ \\
\hline 0il Saturation (initial) (SOi) & $=$ & $54 \%$ \\
\hline Average Permeability & $=$ & 1,500 millidarcies \\
\hline BHT & $=$ & $101^{\circ} \mathrm{F}$ \\
\hline BHP & $=$ & $350 \mathrm{psi}$ \\
\hline Depth to Top Soil & $=$ & $1,030 \mathrm{ft}$ \\
\hline 0il Gravity & $=$ & $18.5^{\circ} \mathrm{API}$ \\
\hline 0il Viscosity & $=$ & $\begin{array}{l}46 \text { centistokes } 0101^{\circ} \mathrm{F} \\
\text { or } 48.8 \text { centipoise }\end{array}$ \\
\hline Original $0 i 1$ in Place (00IP) & $=$ & $\begin{array}{l}\text { 3,000 Thousand Stock } \\
\text { Tank Barrels (MSTB) }\end{array}$ \\
\hline Cumulative Recovery To Date & $=$ & 100 MSTB or $3.3 \%$ OOIP \\
\hline Current Production & $=$ & $20 \mathrm{BOPD}, 1,000 \mathrm{BWPD}$ \\
\hline 5 Producers, & 1 Injector & 2- Shut-in \\
\hline
\end{tabular}

The Laiweroer solution method is highly idealized but its value lies in its ability to quickly screen the possibilities of heating the reservoir to a desired temperature within a specified time frame. The method assumes the following:

A linear, one dimensional, incompressible flow in a homogeneous sand (the reservoir may be substantially heterogeneous),

Constant physical properties and fluid saturations (saturations will change with time due to the thermal effect on oil distillation, capillary forces etc.),

Uniform temperature for any vertical position within the reservoir,

Thermal conductivity is zero in the horizontal direction, and Constant injection rate and injection temperature. 


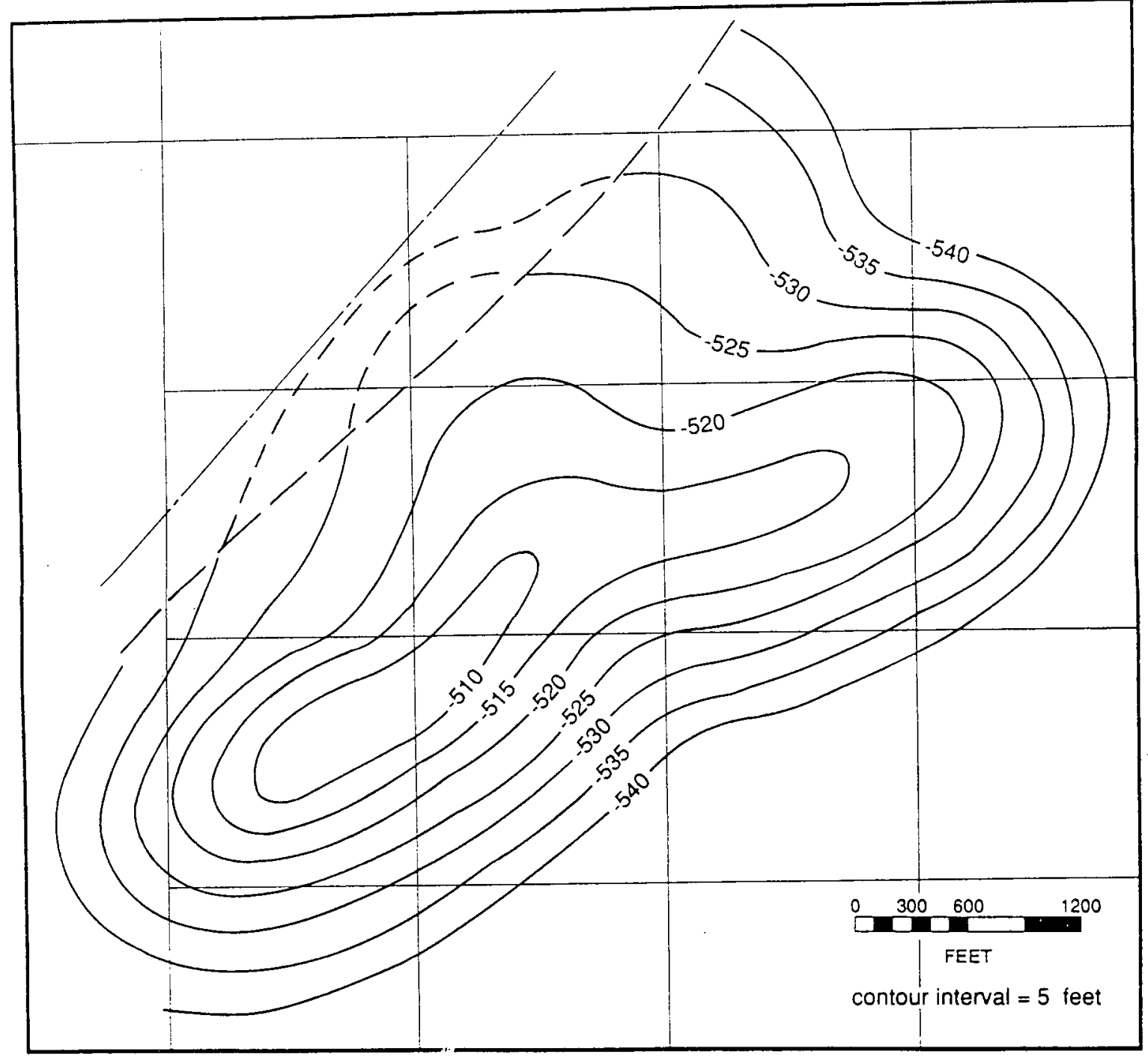

Figure 33. Structure map on top of the cole sandstone, Alworth Field. 


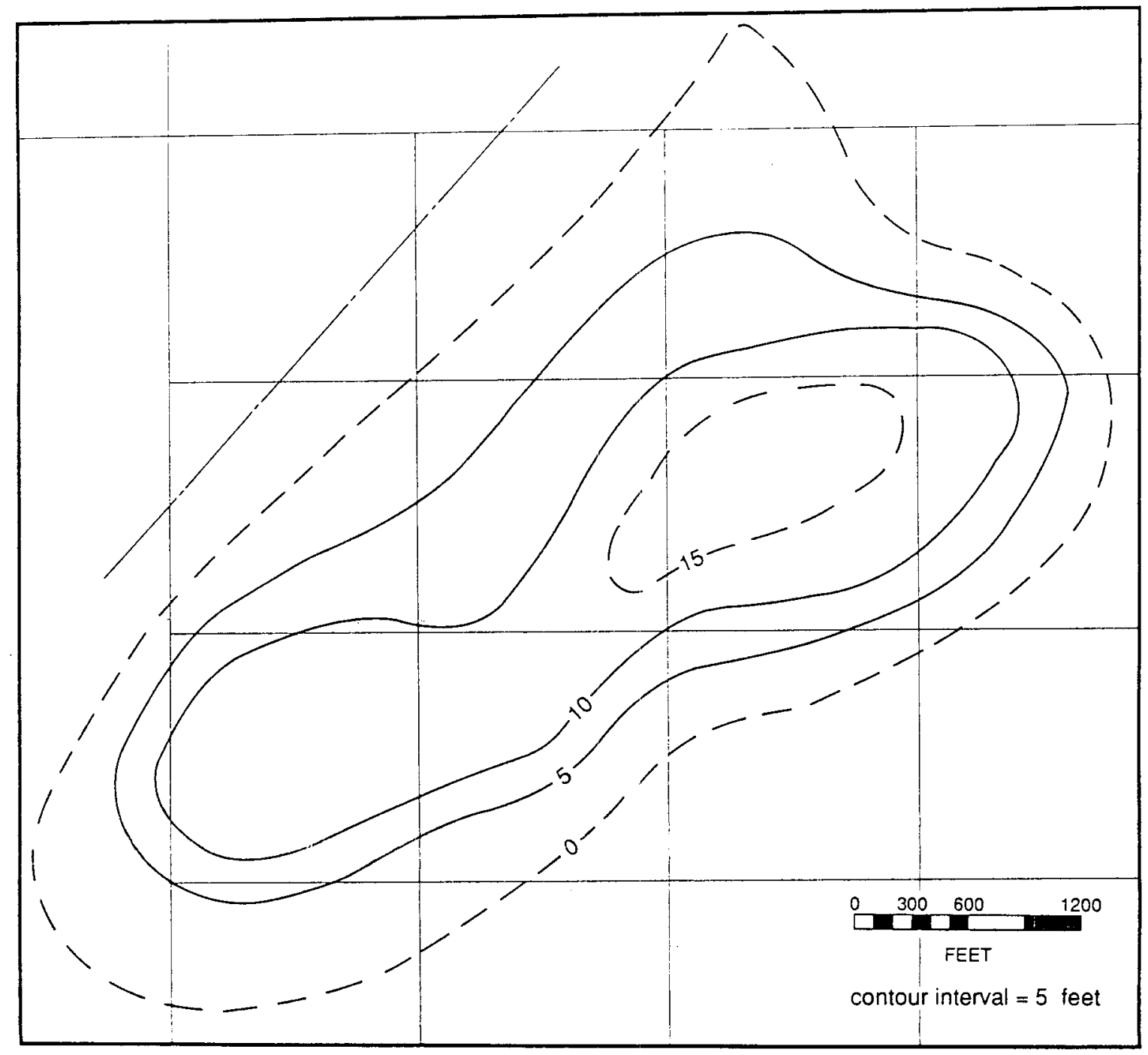

Figure 34. Isopach map of the oil column in the cole sandstone, Alworth Field. 
A 10 acre line drive pattern was used to estimate reservoir temperature distribution with time. Specific assumptions were: an injection rate of $375 \mathrm{bbl} /$ day/well (pattern); a volumetric sweep efficiency of $70 \%$ with 1 inear flow; an average reservoir thickness of $7.5 \mathrm{ft}$; injection temperatures of 338 and $482^{\circ} \mathrm{F}\left(170\right.$ and $\left.250^{\circ} \mathrm{C}\right)$; a 5 acre pattern element with a width of $330 \mathrm{ft}$ and a distance between the injection well and production well of $660 \mathrm{ft}$. At the assumed volumetric sweep efficiency, the pattern element pore volume is $61,000 \mathrm{bbls}$. At a pattern element injection rate of $187.5 \mathrm{bbl} /$ day, the time to inject 1 pore volume is 326 days. The temperature distribution between the injection and production wells at various times are presented in Figures 35 \& 36 .

As noted from Figure 3 the $18^{\circ} \mathrm{API}$ gravity $0 i 1$ from the Alworth Field can have its viscosity reduced from about 100 centipoise at a temperature of $90^{\circ} \mathrm{F}$ $\left(32^{\circ} \mathrm{C}\right)$ to 10 centipoise at $200^{\circ} \mathrm{F}\left(93^{\circ} \mathrm{C}\right)$. Moreover, there will be a thermal expansion of the oil which will further aid oil mobility and recovery. Based on laboratory studies, reservoir models, and field case histories (Boberg, 1988) incremental $0 i 1$ recoveries could be 10 to $30 \%$ of currently estimated total production. The Alworth Field is presently producing about 1,000 bwpd for a water-cut of about $98 \%$. This water is currently being re-injected in an up-dip position. At present it is not known whether the high water cut is due to water coming from below the oil/water contact or is due to channeling from the injection well. Production data are currently available on a field wide basis only. Individual wells must be tested to obtain data to assist in determination of the cause of the high water cut. Methods to resolve the problem need to be evaluated and applied as appropriate. Possible methods could include the use of gelled polymer treatments of producing wells, as well as strategically locating the injectors and producers to reduce the effects of any reservoir heterogeneity that may be identified in the early stages of the program. 


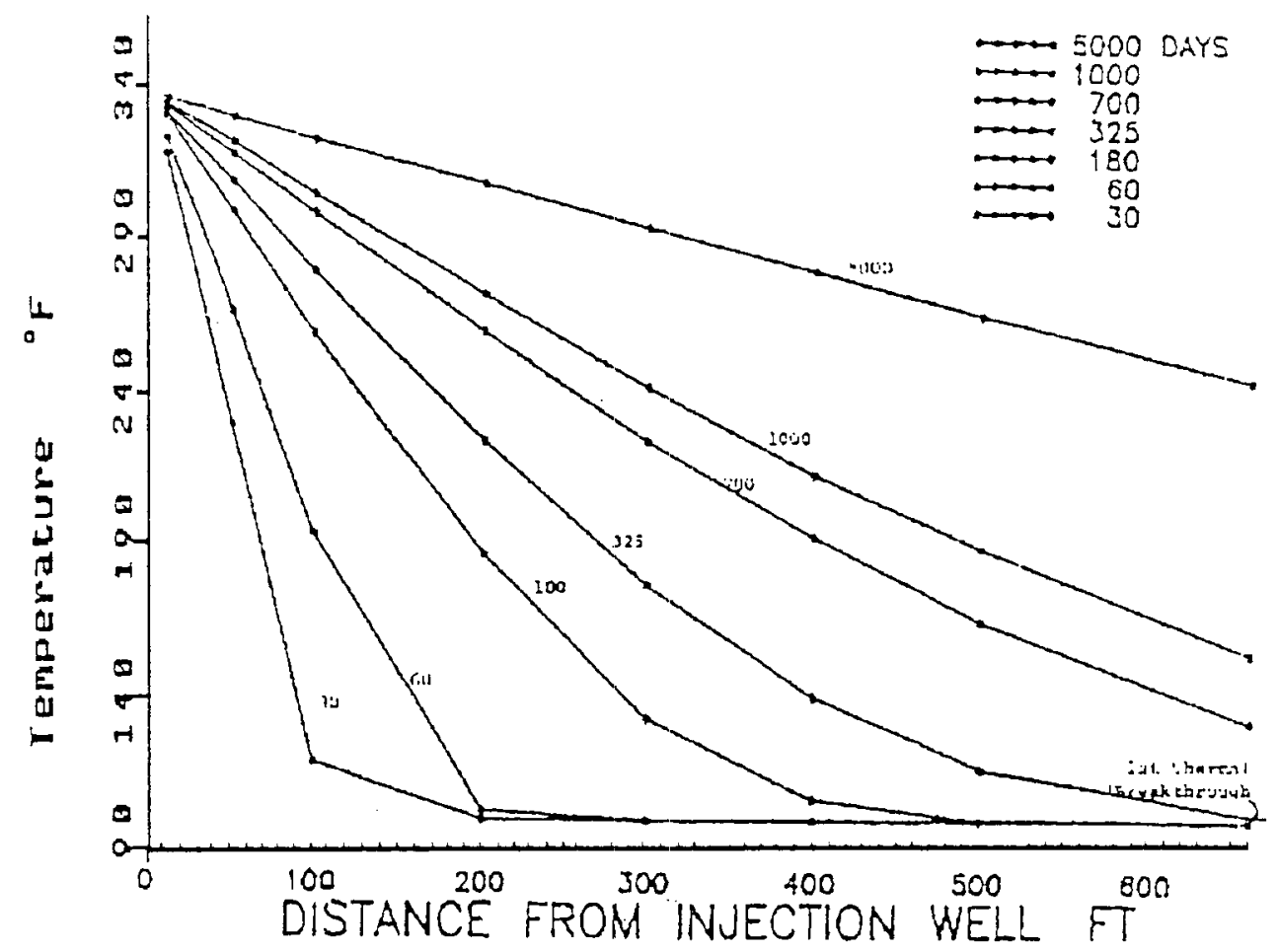

Figure 35. Temperature distribution within a 10 acre line drive: $338^{\circ} \mathrm{F}$ injection water.

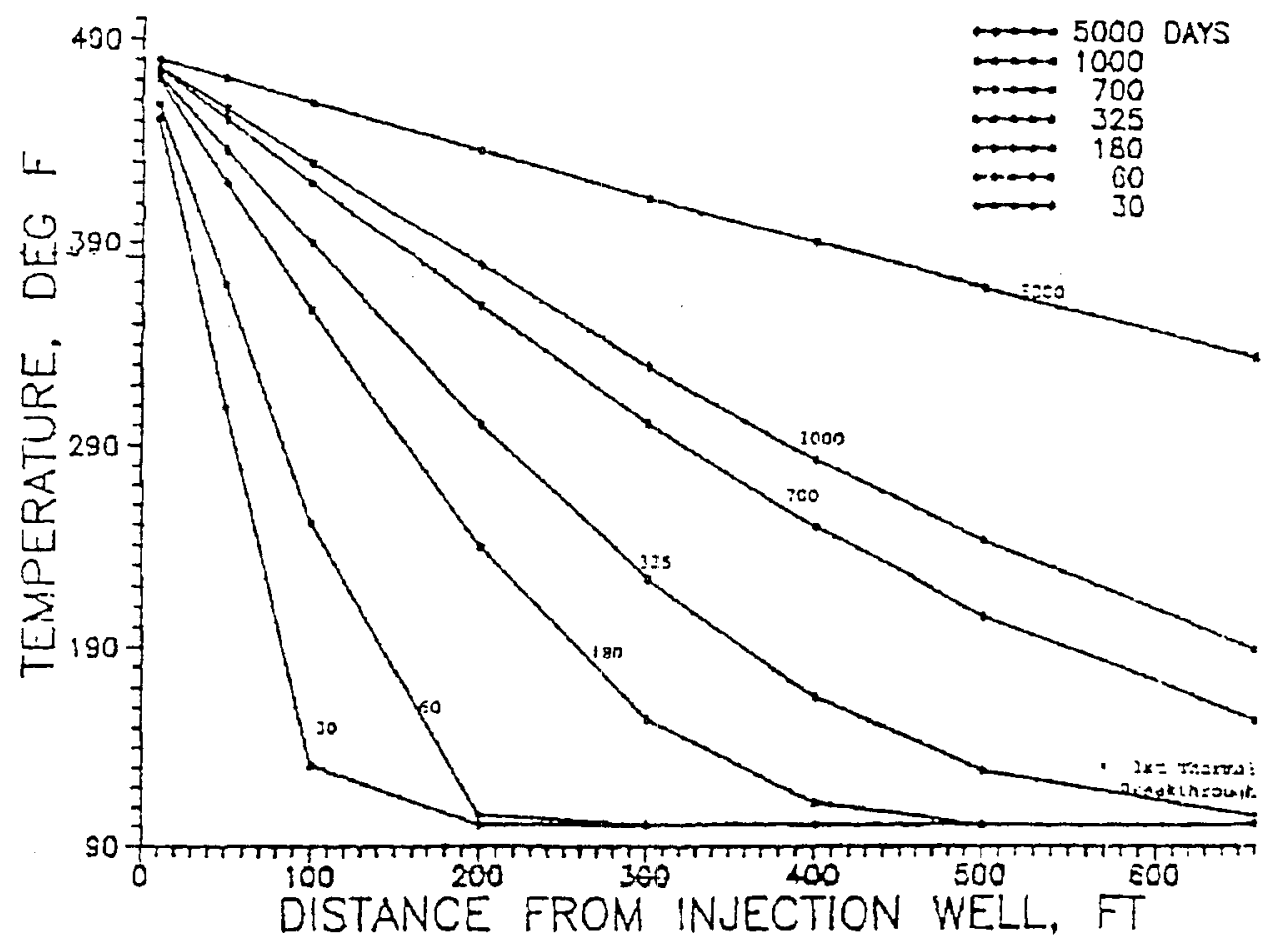

Figure 36. Temperature distribution within a 10 acre line drive: $482^{\circ} \mathrm{F}$. 


\section{ECONOMIC ANALYSIS}

The current direction of the GPGT Program is to develop new technologies to profitably produce electricity for $\$ 0.07$ to $\$ 0.11 / \mathrm{Kwh}$ by 1995 (in 1990 dollars, DOE, 1989), plus investigating various applications for the heat of the resource, including TEOR. Economic analysis suggests that developing the GPGT TEOR resource could be immediately profitable within the set limits.

0il recovery by TEOR is economically feasible if the net value of the oil recovered per unit time exceeds the total cost of recovery per unit time. A realistic economic evaluation of a TEOR project must be of a specific field because of the unique aspects of each reservoir, associated brine well, and regional costs. The Alworth Field of south Texas is used as an example economic analysis because it is regarded as typical of the heavy oil fields found in the "Mirando" trend (Kimmell, 1989). The input data for the Alworth Field pilot study are given in Table 11. These input data were obtained from Fanion Production Company (Kimme11, private communication, 1989), the Otis Division of Haliburton, Schlumberger Inc., and Watson Pipe and Supply of Corpus Christi, Texas. 
Table 11. Economic input data for evaluation of Alworth Field.

TEOR Using Geopressured-Geothermal Brine Model Inputs: 8/10/90

ANALYSIS OF TEOR: SOUTH TEXAS ALWORTH FIELD, UPPER WILCOX FM

COMPUTER MODEL NAME: $6610-2 D$

COMPUTER MODEL DESCRIPTION: Recovery of heavy oil with hot brine

RESULTS: (Assume $1,000,000$ bbl recovery, $100 \mathrm{scf} / \mathrm{bbl}$ )

$\$ / \mathrm{bbl}$ oil recovered $\$ 17.20 / \mathrm{bbl}$ (based on $\$ 25 / \mathrm{bbl}$ oil

BASE YEAR and CONTRACT DOLLARS: 1990

COSTS/EXPENSES:

TOTAL PRE-OPERATION/DEVELOPMENT/CAPITAL COSTS . . . . . . . $\$ 3,986,000$.

$(\$ 3,624,000+10 \%$ cont ingency)

Borrowed Capital

Owners Equity

$\$$

$\$ 3,650,000$

TOTAL DEVELOPMENT COSTS

Site Procurement/Lease

Well Study

Well Engineering

We11 Refurbishment

Well Test

Disposal Well (field)

TOTAL EQUIPMENT COSTS

Gas Line

Transmission

Site Upgrade

Brine Separator/Piping

OIL RECOVERY EQUIPMENT COSTS

Rework Existing Wells

Drill New Production and Injection Wells

Field Study \& Design

Piping for Brine to Field

Brine Capatibility Study

$\$ 2,095,000$

$\$ 135,000$

$\$ 35,000$

$\$ 25,000$

$\$ 1,650,000$

$\$ \frac{\$ 110,000}{\$ 190}$

$\$ 1,529,000$

$\$ 140,000$

\begin{tabular}{cc}
$\frac{240,000}{\$ \quad 85,000}$ \\
\hline & $\$ 125,000$ \\
$\$$ & 85,000 \\
& \\
& 574,000 \\
\hline & 60,000 \\
\hline & 250,000 \\
\hline & 110,000
\end{tabular}

WORKING FUNDS

CAPITALIZED INTEREST

$\$$

TOTAL ANNUAL OPERATION EXPENSES . . . . . . . . \$775,000.

Labor and Administration

Maintenance (\% of capital costs)

Calculated Value

Scale \& Corrosion Inhibitor

Liability \& Operators Extra Exp Insur.

Data Collection, Lab Work, Samples, etc
$\$ 150,000$

\begin{tabular}{cr}
$\$ 185,000$ \\
\hline$\$ 10,000$ \\
\hline$\$ 110,000$ \\
\hline$\$ 240,000$
\end{tabular}


TOTAL POST-OPERATION COSTS

Site Decommisioning

Plug \& Abandon

$\$ 110,000$

SALVAGE

FINANCIAL/TAX/ECONOMIC INPUTS:

Discount Rate (IRR)

$15.0 \%$

Debt Ratio

Interest Rate

Debt Life

$40.0 \%$

$11.0 \%$

Depreciation Life

5 years

7 years

Royalty (\% of revenue)

Taxes:

Federal Tax

State Tax

Severance Tax

Ad Valorem Tax

Inflation Rate

Escalation:

Development and Capital cost

Labor and Administration

$38 \%$

$5 \%$

$5 \%$

$7.5 \%$

$5 \%$

Maintenance

Scale Inhibitor

Insurance

0

0

0

$15 \%$

$\$$

WELL CHARACTERISTICS:

Brine Temp at Surace 300F

Barrels per Day

$20,000 \mathrm{BPD}$

Gas Concentration/Barrel MIN

Gas Quality

$90 \%$

Well Life

10 years

PRODUCTION FACILITY CHARACTERISTICS:

Annual Gas Production

MIN

Assume 3 years production

MAX $480,000 \mathrm{Kscf}(80 \mathrm{scf} / \mathrm{bb})$

$660,000 \mathrm{kSCF}(100 \mathrm{scf} / \mathrm{bb} 7)$

Annual BBLS 0il Prod. 333,333 Barrels (MIN)

Total BBLS Rating of

Facility

Operating Factor

$95 \%$

Plant Life

$1,000,000$ Barrels (MIN)

10 years

The above would generate a cash flow after taxes and royalty of $333,333 \times$ $\$ 17.20+480,000 \times \$ 1.12=\$ 6,270,928 / \mathrm{yr}$. 
The development of the GPGT TEOR resource at a particular location depends largely on being able to gain access to high brine temperatures and suitable target reservoirs. The more or less ubiquitous occurrence of GPGT brine in geopressured basins and the relative ease with which collocational studies can be carried out in the United States, because of the large resident data base, makes the availability of abandoned geopressured wells having suitable temperatures, pressures and brine compositions the major geological concern pertaining to the source reservoir. The economic model assumes such a well is available but allows the brine temperature to vary, as well as the distance between the brine source well and the target well.

Table 12. Production Scenario 1.

\begin{tabular}{|c|c|}
\hline \multicolumn{2}{|c|}{$\begin{array}{l}\text { Assuming: } \\
20,000 \text { BPD of hot brine production } \\
80 \mathrm{scf} \text { gas } / \text { per barrel of hot brine } \\
90 \% \text { of gas is methane } \\
1,000,000 \text { bbls of heavy oil production over a } 3 \\
\text { year period }\end{array}$} \\
\hline \multicolumn{2}{|c|}{ Assuming: $\$ 2.25 / \mathrm{mcf} \& \$ 20.00 / \mathrm{bbl}$} \\
\hline \multicolumn{2}{|l|}{ 15\% Discount: } \\
\hline $\begin{array}{c}\text { Breakeven Discounted Payback } \\
\text { years }\end{array}$ & $\begin{array}{l}\text { NPV } \\
\text { thousands }\end{array}$ \\
\hline$\$ 12.15 / \mathrm{bbl}$ oil & $\$ 3,600$ \\
\hline \multicolumn{2}{|l|}{ 26\% Discount: } \\
\hline $\begin{array}{c}\text { Breakeven Discounted Payback } \\
\text { years }\end{array}$ & $\begin{array}{l}\text { NPV } \\
\text { thous ands }\end{array}$ \\
\hline$\$ 1.30 / \mathrm{mcf} \quad 1.9$ & $\$ 2,300$ \\
\hline & \\
\hline
\end{tabular}


The results of two production scenarios are given in Tables 12 \& 13 for assumed heavy oil production of 1,000,000 bbl and 1,500,000 bbl over a 3 year period. Table 16 shows that input and output values from the model run.

Table 13. Production Scenario 2.

\begin{tabular}{|c|c|}
\hline \multicolumn{2}{|c|}{$\begin{array}{l}\text { Assuming: } \\
20,000 \mathrm{BPD} \text { of hot brine production } \\
80 \mathrm{scf} / \mathrm{gas} / \mathrm{per} \text { barrel of hot brine } \\
90 \% \text { of gas is methane } \\
1,500,000 \text { bbl of heavy oil production over a } 3 \text { year } \\
\text { period }\end{array}$} \\
\hline \multicolumn{2}{|c|}{ Assuming: $\$ 2.25 / \mathrm{mcf} \& \$ 20.00 / \mathrm{bbl}$} \\
\hline $\begin{array}{l}\text { 15\% Discount: } \\
\text { Breakeven } \\
\text { years }\end{array}$ & $\begin{array}{c}\text { Discounted Payback NPV } \\
\text { thousands }\end{array}$ \\
\hline $\begin{array}{l}\$ 0.80 / \mathrm{mcf} \\
\$ 9.25 / \mathrm{bbl} \text { oil }\end{array}$ & $\$ 6,500$ \\
\hline 26\% Discount: & \\
\hline $\begin{array}{l}\text { Breakeven } \\
\text { years }\end{array}$ & $\begin{array}{c}\text { Discounted Payback } \\
\text { thousands }\end{array}$ \\
\hline $\begin{array}{l}\$ 1.00 / \mathrm{mcf} \\
\$ 10.25 / \mathrm{bbl} 0 \mathrm{il} 1\end{array}$ & $\$ 5,900$ \\
\hline
\end{tabular}

The distance between the brine source reservoir and the target wel1 is 2.5 miles with a brine line cost of $\$ 250,000$. Other assumptions are that $90 \%$ of the geopressured gas is methane with $80 \mathrm{scf} / \mathrm{bbl}$ of brine. Tables 12 \& 13 assume the gas will be extracted prior to piping the brine into the target we11. This allows for revenue from the sale of the gas of over $\$ 1,000,000$. Another scenario is to pump the gas directly into the target well where it would be used as additional gas drive within the target reservoir. 
Eventually, part of this gas would be produced along with the heavy oil. Although this would remove the gas revenue it would save on the front-end capital investment, monitoring and insurance, and would be environmentally prudent. An additional assumption is that production of brine will be 1 imited to $20,000 \mathrm{bbl} /$ day. This is easy to attain and is assumed on the basis of controlling sanding at the Pleasant Bayou Site.

The low end of the input data will be represented by independent industry, in an assumed case where only that research effort required to implement the process in a prudent and efficient manner is included in the costs.

Unfortunately, the GPGT TEOR method is an unproven one and therefore there is no body of information from which costs can be accurately estimated, except by comparison with other EOR methods. As shown in Text Figure 37 a significant increase in recovery can result from secondary hot waterflood over that of cold water flood. The well and production costs of DOE GPGT wells are the basis of some of the input data. Experience has shown that there is a significant front-end investment which is associated with the engineering aspects of the brine source well, especially extracting, surface handling and injection of the brine. 


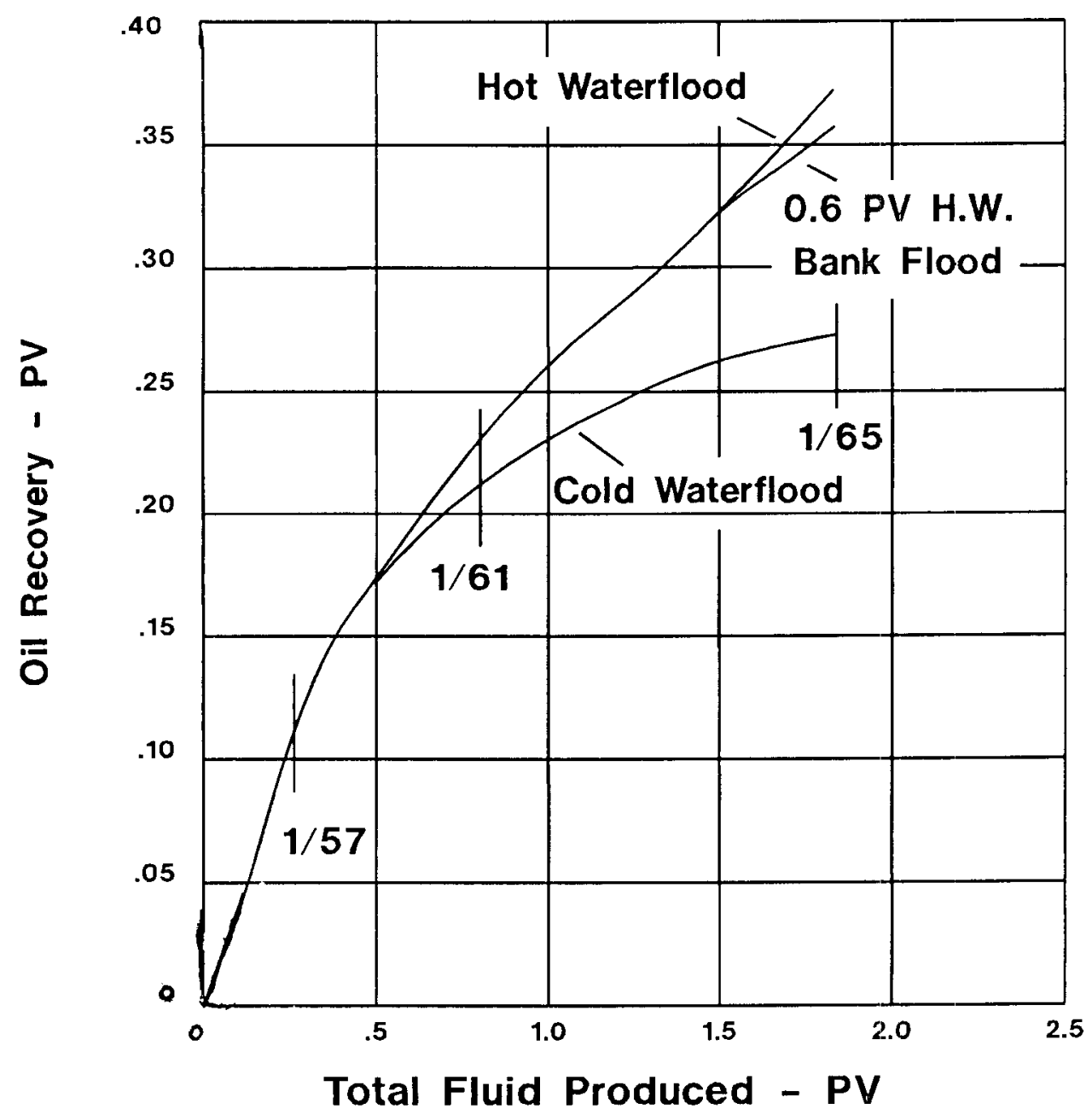

B90 1150

Figure 37. Calculated recoveries for different waterfloods. Source: Spillette \& Nielson, 1968. 



\section{ECONOMIC ASSUMPTIONS}

Investment in the energy industry has proven to be very risky over the last 15 years because of the unstable energy markets and unpredictable price swings. A TEOR project that depends on a geopressured-geothermal project will likely prove to be more risky than other energy investments because of unforeseen production problems in both fields and the higher than normal cost of capital per unit of capacity. Development of an economic model should include these and other variables so that the investor can evaluate all variables and assess their price sensitivity. These variables are discussed in more detail under the following headings: "Financial and Economic Variables," "Preoperation Variables," "Operation Variables," and "Postoperation Variables."

\section{Financial and Economic Variables}

The financial and economic variables are generic to the investment process. The following variables are discussed as the most likely situation faced by a GPGT TEOR energy industry.

\section{Business Type}

The analysis assumes the developer will be a large, successful, and integrated company with technical and financial experience in oil, gas, or geopressured-geothermal development. A large developer allows us to make certain assumptions concerning financing, taxes, and cash flow.

\section{Debt Ratio and Interest Rate}

Two sources of funds are available to a developer: owner's equity and borrowed capital. Currently, the $0 i 1$ and gas industry is capital short and experiencing a reduction of assets. Current debt to equity ratio is 60/40 (U.S. Industrial Outlook, 1989). Assuming these current market conditions, we 
can conservatively estimate a GPGT TEOR developer will be able to borrow $40 \%$ of the capital requirement at the prime lending rate of 10\% (Wall street Journal, August 1990). This allows for $40 \%$ of the brine field development, heavy oil field development, equipment, pipeline, and working funds to be financed by debt. The remaining costs, of site procurement, well study, and well engineering are funded $100 \%$ by owner's equity because these would have to be incurred to prove project feasibility. Construction interest is funded $100 \%$ by debt.

\section{Operating Losses}

Assuming a large developer will have other income streams, operating losses from the GPGT TEOR development will be considered a loss against other income. This allows us to reduce the annual loss against the development by the effective tax rate.

\section{Liquidity}

Assuming a large developer will have a positive cash flows from other operations, all near-term cash requirements will be covered.

\section{Base Year}

The analysis assumed the project would begin construction in 1991; thus 1991 was selected as the base year. Because most of the costs were identified in 1990 dollar values, these values are inflated to 1991 dollar values using the inflation rate and applicable escalation rate. Costs that are estimated in pre-1990 dollars are inflated to 1990 using only the inflation rate. Estimated costs and revenues for the years following 1991 are inflated and escalated to the appropriate year.

\section{Operating Life}

The operating life is dependent upon the projected resource life. The economic analysis considers a 3 year operating life for the TEOR/heavy oil project and 10 years for the geopressured-geothermal/gas project. Operating lives greater than these values for either project were considered very 
optimistic production scenarios. Additionally, the high discount rate preferred in this analysis minimizes the economic gain of most projects beyond the 10 years life.

\section{Debt Life}

The analysis assumes a 3 years debt life, identical to the operating life of the TEOR/heavy oil project. Matching the debt life to 5 or 10 years was not considered because conservative investors typically require a shorter debt life for high-risk investments.

\section{Construction Life}

The analysis assumes a 1-1/2 year construction life, starting 1 to 2 years before the base year. This construction period is referred to as year-0 because the majority of the capital expenditures will occur during this time. Production will begin at the start of year-1 and end in year-3 for the TEOR/heavy 011 , and end in year 10 for the gas production.

\section{Depreciation and Depreciation Life}

The analysis assumes all pre-operational costs will be depreciated by a straight line method over a 3 year period for the TEOR/heavy oil project and 7 years for the gas project according to the 1988 tax 1 aw (Internal Revenue Service 1988). Straight-1ine depreciation is more conservative than accelerated depreciation schedules because the investment is depreciated more slowly over the same number of years. The pre-development costs of well study, engineering, and testing are expended in year-0. There was no salvage value to any equipment, a conservative assumption.

\section{Discount Rate}

The analysis assumes after-tax income rates of 15 and $26 \%$. A $15 \%$ after-tax discount rate is used for those investors that consider the development a normal investment risk for the mineral extraction industry - an optimistic assessment. A $26 \%$ after-tax discount rate is used for those investors that consider the development a high risk. A pre-tax discount rate of 20 to $30 \%$ is typical for oil and gas developments. 
The conservative approach to the economic analysis is enhanced by using the after-tax discount rate and discounting the cash flows to the beginning of the year. Discounting each year's cash flow to the beginning of the year reduces the actual cash flows by 1 year. The after-tax discounting adds to the conservative analysis by paying all taxes before calculating an expected rate of return.

\section{Inflation and Escalation Rates}

Inflation is the general rise in the cost of goods and services within an economy. Using 1982 to 1984 as the base year, the Consumer Price Index (CPI) has inflated from 30.9 (January 1964) to 129.9 (June 1990) for an average of $5.0 \%$ per year (Survey of Current Business, July 1990). The CPI is commonily quoted because it represents a broad range of goods and services within our society. Including the 25 years before January 1964, the average CPI was $4.0 \%$ per year. Escalation is the additional price rise above the rate of inflation.

The analysis conservatively assumes a $5.0 \%$ inflation rate for all preoperational, operational, and post-operational costs and expenses. Additionally, the analysis makes the assumption of escalating oil and gas prices by factors of 1.5 and $1.0 \%$ respectively because of recent world events and the expected world surplus in excess energy, specifically oil and gas.

\section{Depletion Allowance}

The analysis assumes a zero depletion allowance. Depletion is an allowable expense in the oil, gas, and mineral industries to account for the loss of the resource value through production. Because the analysis has assumed a large developer, the new tax law will not allow percentage depletion for any large producer of oil or gas. Except for small producers, depletion allowance is not an acceptable expense, now or in the future (Lucke and Toder, 1987). 


\section{Pre-operational variables}

Pre-operational variables are those costs incurred before the operation of the project. All costs were estimated in 1990 dollars and inflated to 1991 dollar values using only the inflation rate. These costs are discussed under the headings of development, equipment, working capital, and capitalized interest.

\section{Development Costs}

Development costs are those costs incurred before production equipment can be installed. A large portion of these data were estimated by Mr. C. E. Kimme11 (personal communication, 1990).

\section{We11 Lease or Purchase}

The analysis assumes a procurement cost for the geopressured-geothermal well field of $\$ 135,000$; there is no procurement cost for the heavy oil field since the developer is assumed to already own this resource. Development rights on both $0 i 1$ and gas are obtained by a royalty fee equal to $15 \%$ of gross revenues.

\section{We11 Study}

The analysis assumes a $\$ 35,000$ geopressured-geothermal field study to interpret the lithology and production history. These variables are assumed to be understood for the heavy oil field and no costs are assumed.

\section{Well Engineering}

The analysis assumes a $\$ 25,000$ well engineering cost. Included are well logs and analyses necessary to establish the production well's condition and recommend development procedures.

\section{Well Rework}

The analysis includes $\$ 1,650,000$ to rework the geopressured-geothermal source reservoir well and $\$ 85,000$ to rework the heavy oil target well. 


\section{We11 Testing}

The analysis assumes a we11-test cost of $\$ 110,000$ for the geopressured-geothermal well and $\$ 110,000$ for the heavy oil field. Well testing includes short-term flow testing to establish well productivity, to enable accurate brine chemical analyses, and to determine reservoir parameters. This information will be required as input to final equipment design, sizing, process controls, and operations.

\section{Production Well Development}

The analysis includes $\$ 500,000$ to drill a new heavy oil production well.

\section{Injection We11 Development}

The analysis includes $\$ 74,000$ to drill three injection wells in the heavy oil field.

\section{Disposal We11 Development}

The analysis includes $\$ 140,000$ to drill a disposal well in the geopressured-geothermal well field.

\section{Pipeline Right-of-Way Costs}

The analysis assumed no cost to obtain right-of-way for a pipeline between the geopressured-geothermal field reservoir well and the heavy oil field.

\section{Brine Line cost}

The analysis assumed a brine line cost of $\$ 250,000$ to transport the hot brine from the geopressured-geothermal well to the heavy oil field.

\section{Gas Transmission Line}

The analysis assumed a gas 1 ine cost of $\$ 240,000$ to transport the methane gas from the geopressured-geothermal field to an off-site, gas utility line. 


\section{Equipment Costs}

Equipment costs are those costs that are not site specific and can be used at other sites whereas capital expenditures such as well production costs are site specific. The analysis assumed a minimum of equipment costs, primarily for the production of methane gas. These costs include $\$ 45,000$ for pumps, throttles, and controls and $\$ 80,000$ for a pressure separator/dehydrator.

\section{Site Upgrade}

The analysis assumed a minimum cost of $\$ 85,000$ for development of the geopressured-geothermal field and no cost for the heavy oil field because of the previous development.

\section{Working Funds}

The analysis assumed start-up costs of $\$ 100,000$ for the geopressuredgeothermal field and $\$ 50,000$ for the heavy oil field because of the simplicity of equipment and operation.

\section{Contingency}

The analysis assumed a $10 \%$ contingency of the total pre-operational cost to allow for unforseen events and associated costs.

\section{Capitalized Interest}

The analysis assumes all interest from borrowed funds is accrued during the preoperational phase and will be capitalized over the operation life. Capitalized interest is a method whereby the lender (bank) allows interest to accrue without payment during the preoperational phase.

\section{Operational Variables}

Operational variables are either direct costs which vary with the level of production or indirect costs which are fixed year to year and do not vary with the level of production. Labor, material, and direct maintenance vary 
with the level of production although experience indicates that labor is less sensitive to production rates in geothermal development. Common indirect costs include administration, insurance, utilities, and indirect maintenance. All of these expenses are escalated by the general inflation rate.

\section{Labor, Administration, Overhead}

Administration, operations labor, and other indirect costs were assumed to be constant for all levels of production. The geopressured-geothermal gas system and the TEOR heavy oil system will be designed to operate with minimal direct labor. Because of the previous experience in the heavy oil field, these costs are assumed to be $\$ 50,000$ per year compared to the $\$ 100,000$ for the geopressured-geothermal operation.

\section{Royalty}

Royalty is a direct cost of production taken and is calculated as a percentage of gross revenues. This analysis assumes a royalty of $15 \%$ (also see discussion on well lease/purchase, Lucke and Toder, 1987).

\section{Direct Maintenance}

The analysis assumes a direct maintenance expense of $7.5 \%$ of the capital investment on the geopressured-geothermal field, approximately $\$ 185,000$ per year. Because there was very little capital investment in the heavy oil field and because of the short duration of production, the analysis assumed no direct maintenance costs for the heavy oil field.

\section{Direct Materials}

The analysis assumes material costs of $\$ 90,000$ per year for the geopressured-geothermal field. No material costs are assumed for the heavy oil field because of the short duration of production.

\section{Liability and Operators Insurance}

The analysis assumed $\$ 110,000$ a year for liability and operators insurance for the geopressured-geothermal field. The analysis assumed no liability and operators insurance for the heavy oil field and because of the short duration of production. 


\section{Data Collection, Lab Analysis}

The analysis assumed $\$ 240,000(\$ 120,000$ ea) for data collection and analysis to support continuing production goals.

\section{Contingencies}

A contingency factor of $10 \%$ was assumed on a 11 operating costs to cover any unforeseen events and the associated costs. The analysis considers this factor conservative because of the relatively high proportion of fixed costs (administration, insurance, laboratory work) in the operation of both GPGT and heavy oil fields. This contingency is inflated annually by the inflation rate.

\section{Federal, State, and Local Taxes}

The analysis assumes that an Ad Valorem tax of $7.2 \%$, a severance tax of $5.0 \%$, a state tax of $2.0 \%$, and a federal tax of $38.0 \%$ are calculated as a percentage of net income less allowable deductibles.

\section{Production Decline}

This analysis does not assume a graduated production decline in either brine production or in $0 i 1$ production based on the current understanding of both production fields.

\section{Operating Factor}

An operating factor of $95 \%$ was assumed for both hot brine and heavy 011 production fields. The analysis selected a conservative position that the $5 \%$ downtime was unplanned, therefore compounding the operating factor of the heavy oil field $(0.95 \times 0.95=0.90)$.

\section{Operating Rates}

The analysis assumed a geopressured-geothermal brine production of $20,000 \mathrm{~b} / \mathrm{d}(7,300,000 \mathrm{~b} / \mathrm{y})$ and a heavy $0 i 1$ production of $333,333 \mathrm{~b} / \mathrm{y}$ $(913 \mathrm{~b} / \mathrm{d})$. 


\section{Post-Operational Variables}

Post-operational variables include a decommission cost of $\$ 75,000$ and a plug and abandon cost of $\$ 110,000$ for the geopressured-geothermal well field. The analyses did not assume any post-operational costs for the heavy oil well for two reasons. First, the possibility of additional enhanced recovery of this resource would preclude these costs and second, it is reasonable to assume that the previous oil production methods should have set aside a reserve for decommission, and plug and abandon of the heavy oil well.

These analyses assumed no salvage value for any of the physical assets used in the production of either hot brine or heavy oil. In addition, all leases and right-of-way agreements are assumed to have no remaining value.

\section{RESULTS}

The viability of profitably developing a geopressured-geothermal resource to thermally enhance production with TEOR of an existing oil field appears to be extremely good, even under very conservative technical and investment assumptions. This analysis suggests that the breakeven price for $0 i 1$ is less than $\$ 14.00$ per barrel and for gas less than $\$ 2.00$ per thousand cubic feet. Discounted paybacks of less than 2 years would occur under the production scenarios analyzed, and a net present value nearly equal the original value of the investment. These results are summarized in Tables 12 \& 13. 


\section{CONCLUSIONS}

The prime conclusion of this study is that additional heavy and medium oil can be extracted from shallow reservoirs with existing technology that uses geopressured-geothermal brine as the agent for thermal enhanced oil recovery.

When considering the feasibility of using GPGT fluids to recover medium to heavy oil from shallow reservoirs there are a number of global economic factors that must be taken into account In particular, the consumption of oil by the United States will continue to climb. Secondly the domestic production of crude oil within the United States will continue to decline, as shown on Figure 39. Chevron $0 i 1$ Company predicts a $60 \%$ dependence on $0 i 1$ imports by the year 2,000 , as shown on Figures $38 \& 39$. Thirdly, the price of $0 i 1$ will continue to rise (Figure 40). These three factors will affect political, military, and financial developments in the USA. The status of the outlook for crude oil prices prior to the mid-east invasion of Kuwait is shown in Figure 40. One thing that can be done to offset this trend is to increase domestic production.

In order to increase domestic production the number of enhanced $0 i 1$ recovery projects must be increased. It is clear that the recovery mechanisms most successful in secondary and tertiary oil recovery are those involving viscosity reduction. This is best accomplished by thermal enhanced oil recovery techniques. Steam flooding and hot water flooding technology are the established and preferred techniques of Thermal EOR and the reservoir technology involved in steam flooding and hot water flooding is similar to that which could be used with TEOR using GPGT fluids (Blevins, 1990; Beck \& Biggs, 1990). This is particularly apt because viscosity reduction is definitely the most efficient method for heavy oil recovery.

An economic analysis of a possible pilot study area in south Texas indicates that the application of the GPGT TEOR technology to a typical heavy medium oil field would be profitable to any investor. 


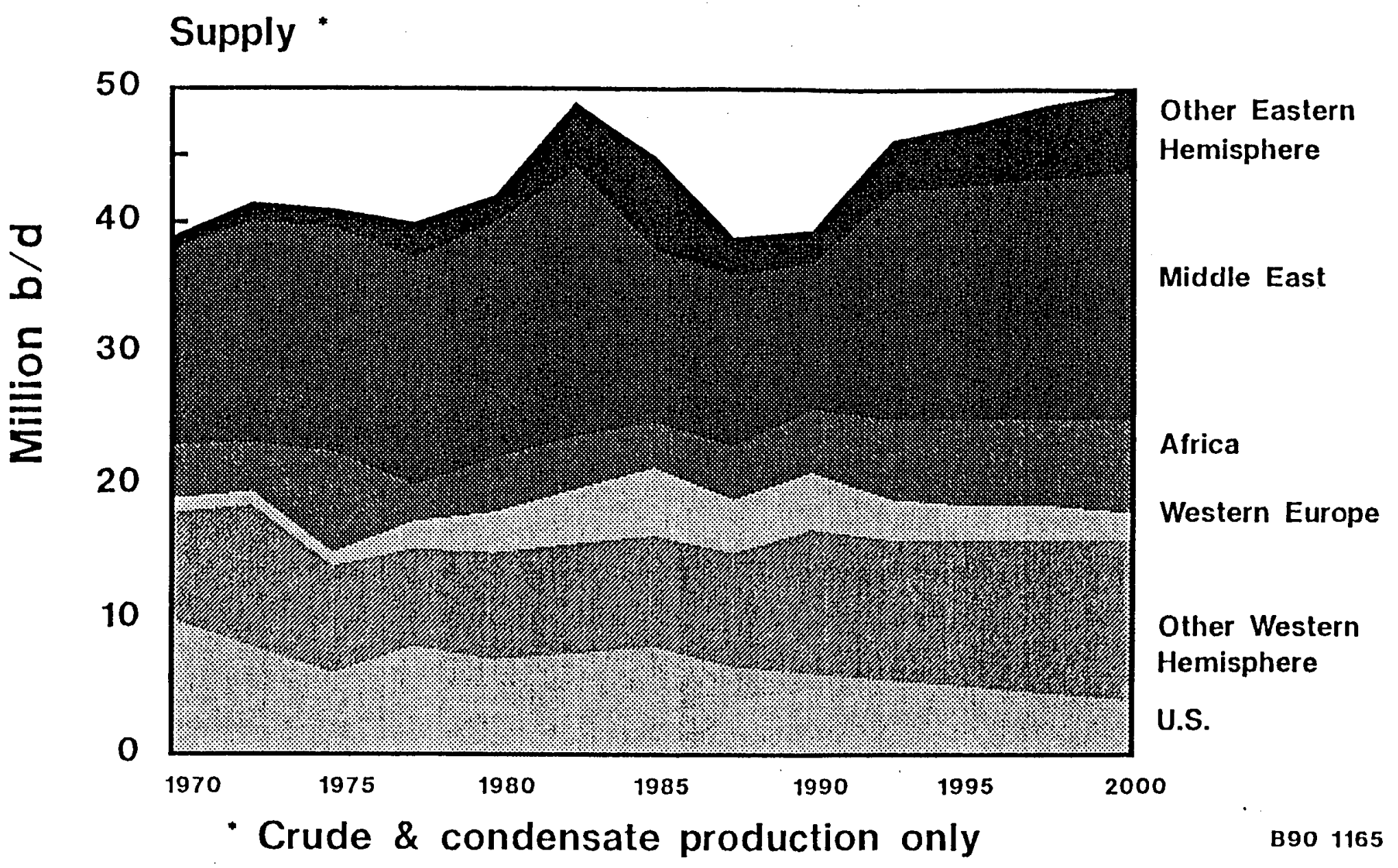

Figure 38. Crude oil supply to 2,000 AD (by export region). Source: (Belvins, 1990) 
Consumption

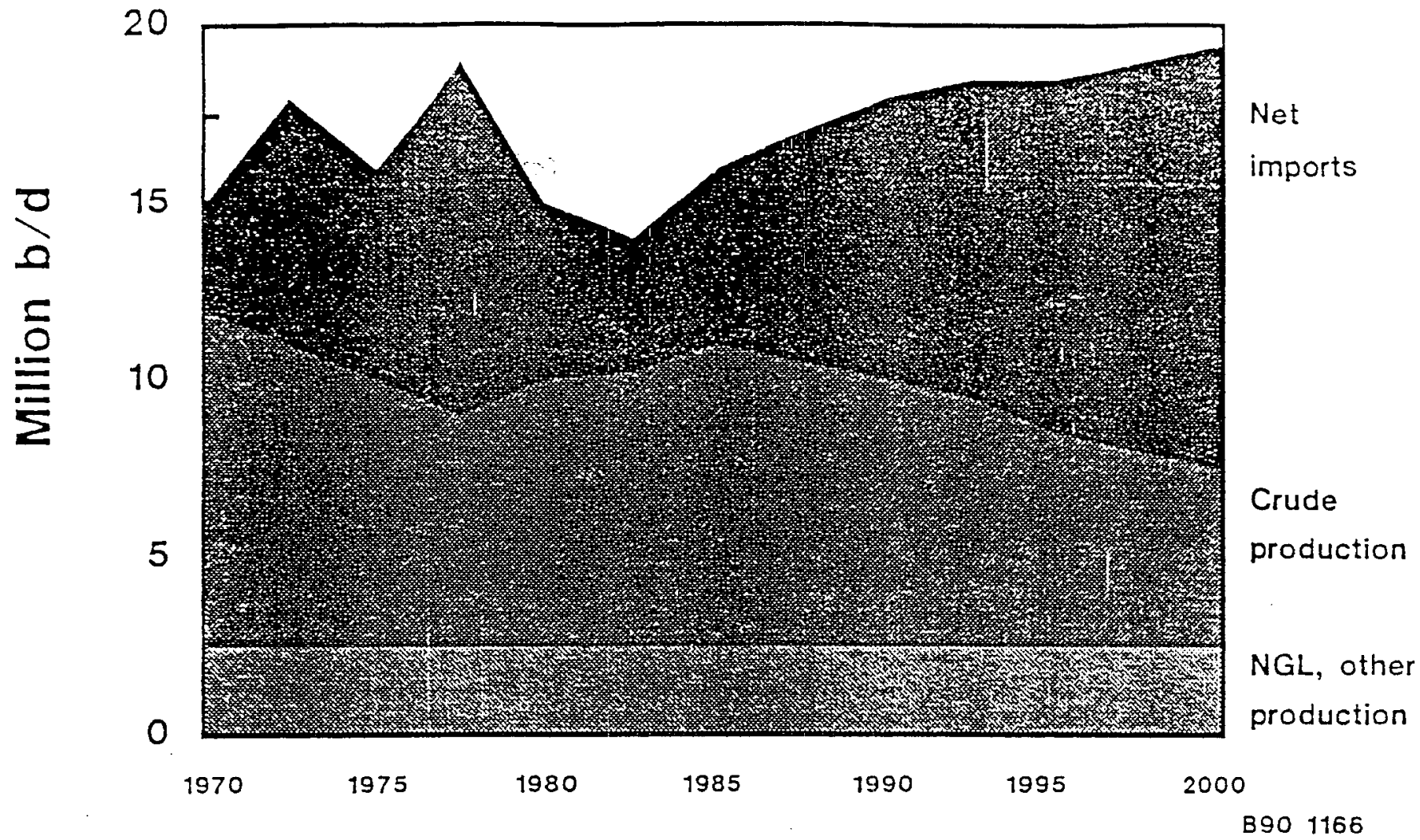

Figure 39. Crude oil consumption to 2,000 AD (USA).

Source: (Belvins, 1990)

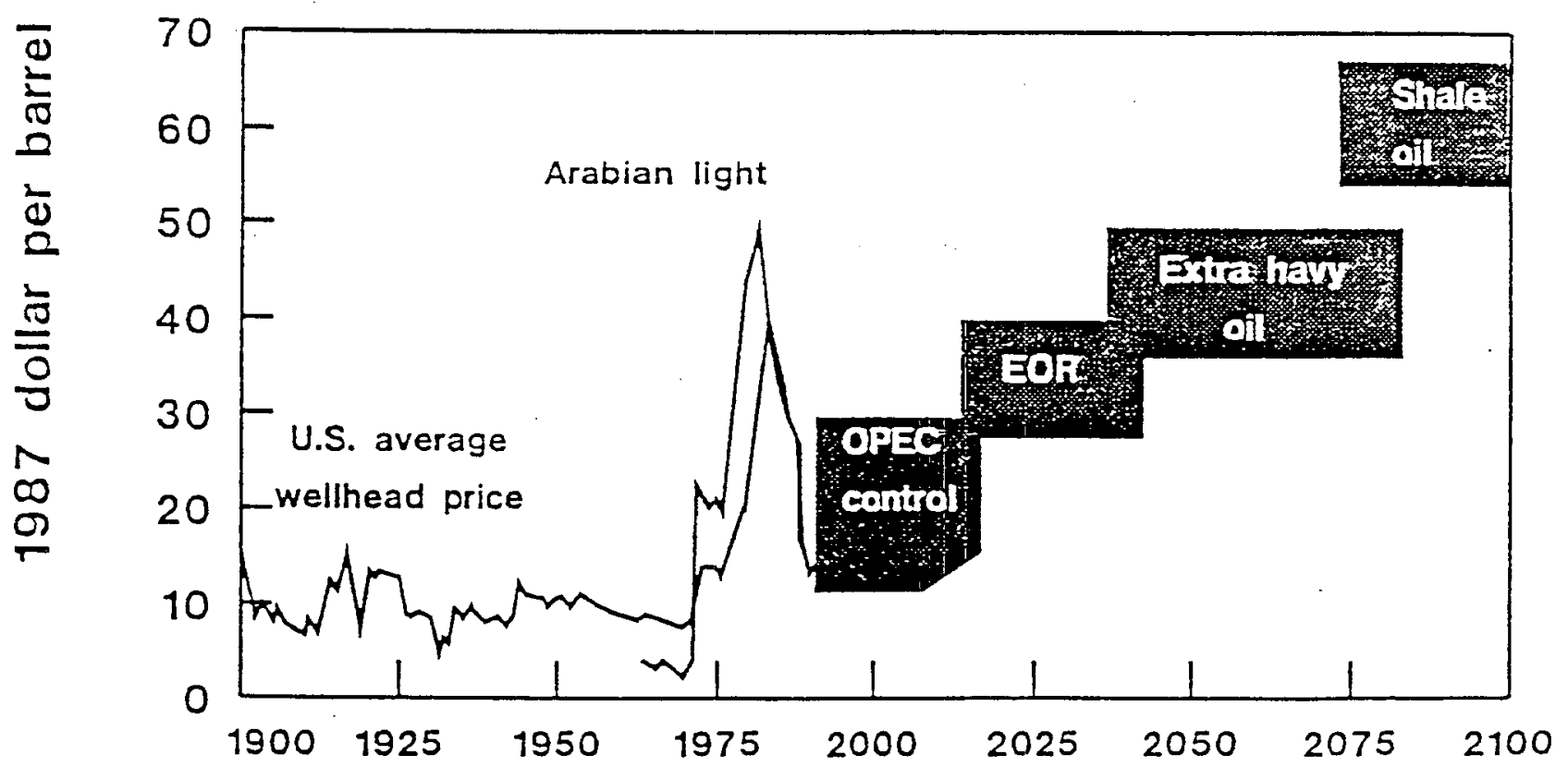

Figure 40 . Crude price outlook to 2,100 AD.

Source: (Belvins, 1990) 
Environmental constraints are an inhibiting factor to expanding or continuing the present level and method of TEOR (Blevins, 1990). The rapid drop in active EOR projects between 1986 to 1988, and the current and future scope of TEOR resulted from lower oil prices and the implementation of environmental constraints. Nonetheless, the total production from EOR projects increased suggesting greater recovery efficiencies. The GPGT TEOR method has a distinct advantage in that it does not pollute the atmosphere. Blevins (1990) concluded after a careful examination of a comprehensive data set:

"future TEOR production will be affected more by environmental regulations than by price regulations....... the impact of ongoing research to improve process technology could flatten out the decline curve" of decreasing thermal oil recovery projects.

In quoting Chevron, Beck and Biggs [1990] noted:

"fossil fuels will continue to dominate energy supplies as the world learns to use There will be a trade-off between standard of living and environmental quality. The challenge of the 1990 s is to find an acceptable balance."

The above observations and the economic analyses presented earlier indicate that the use of GPGT fluids for TEOR is perhaps the currently feasible method that could improve domestic production and add millions of barrels of oil to the recoverable reserves of the United States, as well as to those in many other regions of the world.

Tax incentives will help to stimulate innovation in domestic prduction. An example is the State of Texas where the oil serverance tax was reduced from $4.6 \%$ to $2.7 \%$ in 1989 by the Texas legislature for new tertiary recovery projects that started fluid injection after September 1, 1989. This reduction in the oil serverance tax will be in effect for a 10-year period as long as the project remains active, and applies to all oil from the project, not just the increase from the enhanced recovery processes. North Dakota also has a tax-reduction 1 aw for the operators if in six months a $25 \%$ increase over and above normal decline is achieved using any EOR method. 


\section{REFERENCES}

Aksinat, M. H., 1983, "Gas Evolution and Change of $0 i 1$ Composition During Steam Flooding of 0il Reservoirs," Journal Petroleum Geology, 5, pp. 363-388.

Anonymous, 1973a, "California $0 i 1$ and Gas Fields," California Division of 0il and Gas, Report TR11, 1 , unpaginated.

Anonymous, 1973b, "Seventy-Fourth Annual Report," California Division of 0il and Gas, pp. 61-82.

Anonymous, 1974, "California $0 i 1$ and Gas Fields," California Division of 0il and Gas, Report TR12, 2, unpaginated.

Anonymous, 1989a, "Thermal Enhanced 0il Recovery Using Geopressured-Geothermal Brine," Idaho National Engineering Laboratory pp.1-11.

Anonymous, 1989b, "A Strategy for Maximizing the Producibility of Known U.S. 0i1," DOE Office of Fossil Energy, Report \# DOE/FE-0139.

Associated Press, 1990, The Idaho Statesman, Friday, August.

Bailey J., 1978, "Occurrence of Dissolved Methane Resources in Formation Waters of the Hydropressure Zone in Southern Louisiana." M.S. Thesis, Louisiana State University, Baton Rouge, p. 306.

Bebout, D. G., 1982, "Regional and Local Geologic Setting of the Technadri1Fenix and Scisson-Department of Energy Gladys McCall \#1 Well Site." In R. H. Wallace, Jr., (ed.) "Geopressured-Geothermal Energy Resource Appraisal," Louisiana Geological Survey Guidebook, 2, pp. 49-71.

Bebout, D. G., \& D. R. Gutierrez, 1981, "Geopressured-Geothermal Resource in Texas and Louisiana - Geologic Constraints." In D. G. Bebout \& A. L. Bachman (eds.) "Fifth Conference on Geopressured-Geothermal Energy." Louisiana State University, Baton Rouge, pp. 13-24.

Bebout, D. G., B. R. Weise, \& M. B. Edwards, 1982, "Wilcox Sandstone Reservoirs in the Deep Subsurface Along the Texas Gulf Coast-Their Potential for Production of Geopressured Geothermal Energy." University of Texas at Austin, Bureau of Economic Geology, Report of Investigations 117, p. 125.

Beck R. J., 1990, "0il Industry Outlook," Sixth Edition 1990-1994, Penn Well Publ ishing Company, Box 1260, Tulsa, OK 74101, January, p. 151.

Beck, R. J. \& J. Biggs, 1990, "OGJ Groups Reserves Stable in 1989 but Liquids Production, Drilling Dive," $\underline{0 i l}$ and Gas Journal, May, pp. 23-30.

Berry, F. A. F., 1973, "High Fluid Potential in California Coast Ranges and Their Tectonic Significance," Bullet in American Association Petroleum Geologist, 57, pp. 1219-1249. 
Blevins, T. R., 1990, "Steamflooding in the U.S.," A Status Report, Journal of Petroleum Technology, May, pp. 548-554.

Boberg, T. C., 1988, "Thermal Methods of $0 i 1$ Recovery." An Exxon monograph, J. Wiley \& Sons, Inc., p. 411.

Boberg, T. C. \& R. B. Lantz, 1966, "Calculation of the Production Rate of a Thermally Stimulated We11," Journal of Petroleum Technology, 18, pp. 613-1623.

Bornhauser, M., 1958, "Gulf Coast Tectonics," American Association of Petroleum Geologists Bulletin, 42, pp. 339-370.

Boon, J. A., 1977, "Fluid Rock Interactions During Steam Injection," The 0il lands of Canada-Venezuela, CIM Special 17, pp. 133-138.

Bradley, J. S., 1975, "Abnormal Formation Pressure," American Association of Petroleum Geologists Bulletin, 59(6), p. 957.

Burger, J., P. Sourieau \& M. Combarnous, 1985, "Thermal Methods of $0 i 1$ Recovery," Institut Francais du Petrole Publications, Editions Technip., Gulf Publishing Company, p. 430.

Callaway, D. C., 1968, "Habitat of $0 i 1$ on the West Side, San Joaquin Valley, California," In: S. E. Karp ed., Guidebook - Geology and 0il Fields, West Side Southern San Joaquin Valley. Pacific Sections American Association of Petroleum Geologists, SEG and SEPM, pp. 21-25.

Caughey, C. A., 1975, "Pleistocene Depositional Trends Host Valuable Gulf $0 i 1$ Reserves," 0il and Gas Journal, (Parts 1 \& 2) 73, pp. 91-92 and pp. 240-247.

Des Brandes, R., 1989, "Method and Apparatus for Testing Subsurface Formations," LSU patent reference \#9013 (pending).

Dietzman, W. D., M. Carreles, Jr., \& C. J. Jirik, 1966, "Heavy Crude 0il Reservoirs in the United States," U.S. Bureau of Mines, Information Circular $\underline{8263}$, p. 53.

Dodge, M. M. \& J. S. Posey, 1981, "Structural Cross Sections, Tertiary Formations, Texas Gulf Coast," The University of Texas at Austin, Bureau of Economic Geology, Cross Sections, p. 6.

Department of Energy, 1989, "A Strategy for Maximizing the Producibility of Known U.S. 0i1," DOE/FE-0139.

Department of Energy, 1989, "Geothermal Energy Program Summary, Overview Fiscal Year 1988," Geothermal Technology Division, U.S. Department of Energy, Washington, DC, 1, p. 11 . 
D0E/EIA, "Energy Monthly Review," August 1989, DOE/EIA-0035 (May 1989) D0E, 1989, Geothermal Energy Program Summary, Overview Fiscal Year 1988, Geothermal Technology Division, U.S. Department of Energy, Washington, D.C., 1, p. 11 .

Durham, L. S., 1980, "Enhanced 0il Recovery and Its Potential Application to Louisiana Reservoirs." State of Louisiana, Department of Natural Resources, p. 77.

Eaton, B. C., C. R. Featherston, \& T. E. Meah1, 1988, "U.S. Gulf Coast DOE Geopressured-Geothermal Energy Program Field Research Site Operations FY-1986 to Present Accomplishments and Goals," Proceedings, ASME Geothermal Energy Symposium, New Orleans, LA.

Eaton, B., February 1989, Eaton Operating Company, Monthly Status Report.

Ewing, T. E., 1983, Jackson-Yegua Barrier/Strandplain Sandstone, in W. E. Galloway, T. E. Ewing, C. M. Garrett, N. Tyler, \& D. G. Bebout, "Atlas of Major Texas 0il Reservoirs," The University of Texas at Austin, Bureau of Economic Geology, Special Publication, pp. 30-32.

Fert1, W. H., G. V. Chilingarian, \& H. H. Rieke, III, 1976, "Abnormal Formation Pressures," Elsevier Scientific Publishing Co., New York, p. 382.

Fert1, W. H. \& G. V. Chilingarian, 1977, "Importance of Abnormal Formation Pressures," Journal Petroleum Technology, p. 347.

Fertl W. H., G. V. Chilingarian, \& H. H. Rieke III, "Abnormal Formation Pressures," Elsevier Scientific Publishing Company, New York, NY, p. 382.

Feber, R. C., 1979, "Proceedings of Workshop on Scale Control in Geothermal Energy Extraction Systems," LoS Alamos Scientific Laboratory Report, LA-7664C.

Fisher, W. L., 1969, "Facies Characterization of Gulf Coast Basin Delta Systems, With Some Holocene Analogues," Gulf Coast Association of Geological Societies Transactions, 19, pp. 239-261.

Fisher W. L., W. L. Procter Jr., W. E. Galloway, \& J. S. Nagle, 1970, "Depositional Systems In The Jackson Group of Texas--Their Relationship to 0 il, Gas, and Uranium," The University of Texas at Austin, Bureau of Economic Geology, Geological Circular 70-4, p. 28.

Foss, C. D. \& R. Blaisde11, 1968, "Stratigraphy of The West Side Southern San Joaquin Valley" in S. E. Karp, ed., Guidebook--Geology and 0ilfields, West Side Southern San Joaquin Valley: Pacific Sections--American Association of Petroleum Geologist, Society of Exploration Geophysicists, and Society of Economic Paleontologists and Mineralogist, pp. 33-43.

Graham, S. A. \& L. A. Williams, 1984, "Tectonic, Depositional and Digenetic History of Monterey Formation (Miocene), " Central San Joaquin Basin, Cal ifornia, American Association of Petroleum Geologists Bulletin, 69, pp. 385-410. 
Gregory, A. R., M. M. Dodge, J. S. Posey, \& R. A. Morton, 1980, "Volume and Accessibility of Entrained (Solution) Methane in Deep Geopressured

Reservoirs--Tertiary Formations of the Texas Gulf Coast", The University of Texas at Austin. Bureau of Economic Geology, final report prepared for the U.S. Department of Energy, Division of Geothermal Energy, under Contract No. DE-AC08-78ET11397, p. 390.

Grim, R. E., 1968, "Clay Mineralogy," McGraw Hill, New York.

Hamlin, S. H., T. G. Walter, \& C. W. Kreitler, 1990, "Collocation of Heavy $0 i 1$ and Geopressured-Geothermal Brine Resources," Examples from South Texas and Kern County, California. Proceeding of the Industrial Consortium for the Utilization of the Geopressured-Geothermal Resource, J. Negus-de Wys, EG\&G Idaho, Inc., Idaho National Engineering Laboratory, 2, pp. 17-55.

Hyne, J. B., 1984, "Aquathermolys is of Heavy 0ils," Second International Conference. "The Future of Heavy Crude and Tar Sands," McGraw Hill, New York, pp. 404-411.

Hanor, J. S., 1981, "Geochemistry of Geopressured Brines in South Louisiana: Potential for Reaction with Injected Geopressured Waste Waters," Proceedings Fifth Conference on Geopressured-Geothermal Energy, pp. 153-158.

Hanor, J. S., 1983, "Fifty Years of Development of Thought on the Origin and Evolution of Subsurface Sedimentary Brines." In: Boardman, S. J. (ed.), Revolution in the Earth Sciences: Advances in the Past Half-Century. Kenda11/Hunt, Dubuque, p. 385.

Hanor, J. S. \& J. Bailey, 1983, "Use of Hydraulic Head and Hydraulic Gradient to Characterize Geopressured Sediments and the Direction of Fluid Migration in the Louisiana Gulf Coast," Transactions of the Gulf Coast Association of Geological Societies, XXXIII, pp. 115-122.

Hart, G. F., 1989, "The Origin and Classification of Macerals in Clastic Systems," Palynology, 10, pp. 1-23.

Hart, G. F., R. E. Ferrel1, D. Lowe, \& A. E. Lenoir, 1989, "Shelf Sands of the Robulus L zone, Offshore Louisiana." In: Nummedal D. (ed) Shelf Sedimentation, Shelf Sequences, and Related Hydrocarbon Accumulation, Proceedings of the seventh Annual Research Conference, Gulf Coast Section, SEPM: 117-141.

Hart, G. F., C. John, D. Stevens, \& W. B. Evans, 1991, "Collocation of Heavy and Medium $0 i 1$ and Geopressured-Geothermal Brine Resources in Louisiana," Proceeding of the Second Industrial Consortium for the Utilization of the Geopressured-Geothermal Resource. Baton Rouge Meeting, May, 1989. J. Nequs-de Wys, EG\&G Idaho, Inc., Idaho National Engineering Laboratory.

Hui Xu \& R. Des Brandes, 1989, "Formation Evaluation Using in situ Measurements of Formation Thermal Properties." 
Hutcheon, I., 1984, "A Review of Artificial Digenesis During Thermally Enhanced Recovery," In: D. A. McDonald \& R. C. Surdam (eds) Clastic Digenesis, American Association of Petroleum Geologists Memoir 37, pp. 413429.

Jackson, T. \& M. Light, 1987, "Estimate Percentage of Wells Producing from Geopressure Reservoirs Along the Texas Gulf Coast," informal letter report, UTA-Bureau of Economic Geology, p. 3.

John, C. J., 1988, "Geology of the Gladys McCall Geopressured-Geothermal Prospect," Cameron Parish, Louisiana, Journal of Energy Resources Technology, $\underline{110}$, pp. 255-261.

John, C. J., D. A. Stevenson, \& C. G. Groat, 1990, Geopressured-Geothermal Resources in South Louisiana: Current Prospects, Geology, and Environmental Monitoring," South Texas Geological Society Bulletin, San Antonia, January.

Jones, 1976, "Natural Gas Resources of the Geopressured Zones in the Northern Gulf of Mexico Basin," In: Natural Gas from Unconventional Geologic resources. The National Research Council, Board of Mineral Resources, Commission on Natural Resources, National Academy of Sciences, pp. 17-33.

Kerrisk, J. F., 1981, "Chemical Equilibrium Calculations for Aqueous Geothermal Brines." Los Alamos Scientific Laboratory report. LA-8851-MS, pp. $1-21$.

Kimme11, C., 1989, "Regional Application of High Temperature-High Pressure Deep Saline Waters for Enhanced Recovery of $0 i 1$ from $0 i l$ Fields Along the 'Mirando' Trend of South Texas." DOE Report, Proposal.

Kimme11, C. E., J. Negus-de Wys, \& B. Eaton, 1989, "Thermal Enhanced $0 i 1$ Recovery [TEOR] of Heavy $0 i 1$ Using Geopressured-Geothermal Brine, "Joint Venture Technical Proposal, EG\&G Idaho, Inc., Eaton Operating Company, Inc., and Fanion Production Company, 1, pp. 1-69.

Kosters, E. C. \& H. S. Hamlin, 1989, "WX-4 Wilcox Deltaic Sandstone in the Rio Grande Embayment," in E. C. Kosters, D. G. Bebout, S. J. Seni, C. M. Garrett, Jr., L. F. Brown, Jr., H. S. Haml in, S. P. Dutton, S. C. Ruppel, R. J. Finley, and Noel Tyler, Atlas of Major Texas Gas Reservoirs: The University of Texas at Austin, Bureau of Economic Geology, Special Publication, pp. 17-20.

Kuuskraa \& Godec, 1987, Interstate $0 i 1$ Compact Commission Report, DOE, Bartlesville Project Office.

Lauwerier, H. A., 1955, "The Transport of Heat in an 0 il Layer Caused by the Injection of Hot Fluid," Applied Science Research, Sec A, $\underline{5}, p .145$.

Leutwyler, K. \& H. L. Bigelow, 1965, "Temperature Effect on Subsurface Equipment in Steam Injection Systems," Transactions AIME, 234, I-93.

Lucke, R. \& E. Toder, October 1987, "Assessing the U.S. Federal Tax Burden on $0 i 1$ and Gas Extraction," The Energy Journal. 
Loucks, R. G., M. M. Dodge, \& W. E. Galloway, 1979, "Sandstone Consolidation Analysis to Delineate Areas of High Quality Reservoirs Suitable for Production of Geopressured-Geothermal Energy Along the Texas Gulf Coast." Report to U.S. Department of Energy, Division of Geothermal Energy, Contract \# EG-77-5-155551, The University of Texas at Austin, Bureau of Economic Geology, pp. 1-97.

MacPherson, B. A., 1978, "Sedimentation and Trapping Mechanism in Upper Miocene Stevens and 01der Turbidite Fans of Southeastern San Joaquin Valley, California," American Association of Petroleum Geologists Bulletin, $\underline{62}$, pp. 2243-2274.

McGuire, M. D., J. R. Bowersox \& L. J. Earnest, 1984, "Diagenetically Enhanced Entrapment of Hydrocarbons--Southeastern Lost Hills Fracture Shale Pool," Kern County Cal ifornia, San Jaoquin Geological Society Selected Papers, $\underline{6}$, pp. 40-49.

Marx, J. W. \& R. N. Langenheim, 1959, "Reservoir Heating by Hot Fluid Injection," Transactions of AIME, 216:312.

Matthews, C. S., 1980, "Gas Evolution from Geopressured Brines," U.S. Department of Energy, Washington, D.C., Publication \# DOE/TIC-11227, pp. 1-50.

Michels, D. E., 1980, "Deposition of $\mathrm{CaCO}_{2}$ in Porous Materials by Flashing Geothermal Fluid," Geothermal Reservoir Engineering Management Program, Earth Science Division, Lawrence Berkeley Laboratory, Berkeley, Publication LBL10673, GREMP-9, UC-66d, p. 28.

Miche1s, D. E., 1981, " $\mathrm{CO}_{2}$ and Carbonate Chemistry Applied to Geothermal Engineering," Geothermal Reservoir Engineering Management Program, Earth Science Division, Lawrence Berkeley Laboratory, Berkeley, Publication LBL11509, GREMP-15, UC-66c.

Monin, J. C. \& A. Audibert, 1984, "Alteration of Heavy Crudes Under High Pressure Steam Conditions," American Chemical Society, Division of Petroleum Chemistry, Preprints, 29(4), pp. 1223-1231.

Morton R. A., T. E. Ewing, \& N. Tyler, 1983, "Continuity and Internal Properties of Gulf Coast Sandstones and Their Implications for Geopressured Fluid Production," The University of Texas at Austin, Bureau of Economic Geology, Report of Investigations No. 132, p. 70.

Moritas, G., April 1990, "OGS Special: Annual Production Report, C02 and HC Injection Lead EOR Production Increase," 0il and Gas Journal, pp. 49-82.

Negus-de Wys, J., 1989a, "Thermal Enhanced 0 il Recovery (TEOR) Using Geopressured-Geotherma1 Brine," EGG-PRO-003-89, prepared under DOE Contract No. $D E-A C 07=761 D 01570$.

Negus-de Wys, J., 1989b, "Properties of Geopressured Brines and Wells in the Gulf Coast and Opportunities for Industrial/Research Participation,"

Geothermal Resources Council Transactions, Vol. 13, pp. 115-122. 
Negus-de Wys, J., 1989c, "Thermal Enhanced $0 i 1$ Recovery [TEOR] Using Geopressured-Geothermal Brine." Idaho National Engineering Laboratory, pp. $1-11$.

Negus-de Wys, J., 1989d, "Properties of Geopressured Brines and Wells in the Gulf Coast and Opportunities for Industrial/Research Participation." Geothermal Resources Council Transactions, 13, pp. 115-122.

Negus-de Wys, J. \& M. Dorfman, 1990, "The Geopressured Resource:Transition to Commercialization," Geothermal Resources Council Transactions, August GRC Meeting, Hawai .

Negus-de Wys, J., 1991, "The Geopressured Habitat," Idaho National Engineering Laboratory, in preparation.

Nehring, R., R. Hess \& M. Kamioinski, 1983, "The Heavy 0il Resources of the United States," Rand Corporation, Contract Report Prepared for the U.S.

Department of Energy, under Contract No. R-2946-D0E, p. 143.

Ocamb, R. D., 1961, "Growth Faults of South Louisiana." Transactions of the Gulf Coast Association of Geological Societies, 11, pp. 139-175.

Plum, M. M., J. Negus-de Wys, D. D. Faulder \& B. C. Lunis, "Economic Review of the Geopressured-Geothermal Resource with Recommendations, "Idaho National Engineering Laboratory, Idaho Falls, ID, EGG-2581, work performed under DOE Contract No. DE-AC07-761D01570.

Rainwater, E. H., 1967, "Resume of Jurassic to Recent Sedimentation History of the Gulf of Mexico Basin," Iransactions of the Gulf Coast Association of Geological Societies, 17, pp. 179-210.

Rainwater, E. H., 1968, "Geological History and $0 i 1$ and Gas Potential of the Central Gulf Coast," Iransactions of the Gulf Coast Association of Geological Societies, 18, pp. 124-165.

Railroad Commission of Texas, 1989, $19880 i 1$ and Gas Annual Report, 1, p. 428.

Riney, T. D., 1988, "Gladys McCall Geopressured Reservoir Analysis." Proceeding, Eleventh Annual Energy Source Conference and Exhibit, pp. 153-160.

Reed, M.G., 1980, "Gravel Pack and Formation Sandstone Dissolution During Steam Injection," Journal of Petroleum Technology, 32, pp. 941-949.

Sanuquet B., and B. Corre, 1982, "Injection de vapeur en milieu carbonate fissur." Pilote de Lacg Superieur, Second European Symposium, Enhanced $0 i l$ Recovery, Editions Technip, Paris, pp. 611-623.

Sarathi, P., 1991, "Environmental Aspects of Heavy 011 Recovery by Thermal EOR Processes," SPE No.1169598 IIT Research Institutes, National Institute for Petroleum and Energy Research, P.0. Box 2128, Bartlesville, OK 74005, 1991. 
Schaeper D., M. Sloan, \& M. B. Tomson, 1989, "Evaluation of Threshold $\mathrm{CaCO}_{2}$ Scale Inhibitors for Geopressured Brines."

Seni, S., 1991, "Preliminary Results of Collocation Study of Geopressured Brines and Medium to Heavy 0ils in South Texas," Geopressured-Geothermal Program Review, San Francisco, CA, 1991.

Schultz, A. L., 1982, "Geology of the First Mirando Sand, South Lopez Unit, Lopez Field, Webb and Duval Counties, Texas," South Texas Geological Society Bulletin, 22,7, 1982, pp. 11-24.

Spillette, A.G., 1965, "Heat Transfer During Hot Fluid Injection into an 0il Reservoir." Journal of Canadian Petroleum Technology, October-December, p. 213.

Spillette, A.G. \& R. L. Nielson, 1968, "Two Dimensional Method for Predicting Hot Water Flood Recovery Behavior," AIME, p. 243.

Strongin, 0., 1981, "Identification of Geopressured Occurrences Outside of the Gulf Coast." Phase II, final report. Department of Energy, Nevada Operations Office, Contract \# DE-AC08-80NV10133.

Thomas, D.,1979, "Possible Geopressured Well at Huntington Beach, California," California Division of $0 i 1$ and Gas, Geothermal Hot Line, 9, 3, pp. 8-9.

Tomson, M. B., 1982, "Effect of Precipitation Inhibitors on $\mathrm{CaCO}_{3} \mathrm{Scale}$ Formation." Journal Crystal Growth.

Timko, D. J. \& W. H. Fert1, 1971, "Relationship Between Hydrocarbon Accumulation and Geopressure and Its Economic Significance." Journal Petroleum Technology, p. 923.

Oatesan, V. N., \& W. R. SHU, 1984, "Alteration of Heavy 0 il Characteristics During Thermal Recovery," Annual meeting of the Petroleum Society, CIM.

Petroleum Society CIM paper 4, pp. 84-35-108.

Orstramd, C. E., 1934, "Temperature Gradients, in W. E. Wrather, and F. H. Lahee, eds., Problems of Petroleum Geology" American Association of Petroleum Geologists, Sidney Powers Memorial Volume, 1934, pp. 989-1021.

Wallace, R. H., T. F. Kraemer, R. E. Taylor \& J. B. Wesselman, 1979, "Assessment of Geopressured-Geothermal Resources in the Northern Gulf of Mexico Basin," in Muffler, L.J.P., ed., Assessment of Geothermal Resources of the United States-1978: U.S. Geological Survey Circular 790, p. 132-155.

Weedle, J. R., 1968, "0ilfield Waters in Southwestern San Joaquin Valley, Kern County," California in Karp, S.E., ed., Guidebook--Geology and Oilfields, West Side Southern San Joaquin Valley, Pacific Sections--American Association of Petroleum Geologist, Society of Exploration Geophysicists, and Society of Economic Paleontologists and Mineralogists, pp. 25-32.

Wall Street Journal, January \& August 1990. 
Williams, B., 1988, "California Thermal EOR Expansions Still on Track Despite Low $0 i 1$ Prices." 0il and Gas Journal, 19, pp. 19-21.

Williamson, J. D. U., 1959, "Gulf Coast Cenozoic History." Transactions of the Gulf Cost Association of Geological Societies, 9 , pp. 15-29.

Woodbury, H. 0., I. B. Murray, Jr., P. J. Pickford, \& W. H. Akers, 1973, Pliocene and Pleistocene Depocenters, Outer Continental Shelf, Louisiana and Texas." American Association of Petroleum Geologists Bulletin 57, pp. 24292439.

Yerkes, R. F., T. H. McCColloch, J. E. Schoel1hamer, \& J. G. Devedder, 1965, Geology of the Los Angeles Basin--An Introduction, U.S. Geological Survey Professional Paper 420-A, p. 57. 